\title{
Synthesis of benzocarbazoles, indoloquinolines and indolonaphthridines from thermolysis of benzoenynyl ketenimines and carbodiimides
}

\author{
Chongsheng Shi \\ West Virginia University
}

Follow this and additional works at: https://researchrepository.wvu.edu/etd

\section{Recommended Citation}

Shi, Chongsheng, "Synthesis of benzocarbazoles, indoloquinolines and indolonaphthridines from thermolysis of benzoenynyl ketenimines and carbodiimides" (2001). Graduate Theses, Dissertations, and Problem Reports. 1444.

https://researchrepository.wvu.edu/etd/1444

This Dissertation is protected by copyright and/or related rights. It has been brought to you by the The Research Repository @ WVU with permission from the rights-holder(s). You are free to use this Dissertation in any way that is permitted by the copyright and related rights legislation that applies to your use. For other uses you must obtain permission from the rights-holder(s) directly, unless additional rights are indicated by a Creative Commons license in the record and/ or on the work itself. This Dissertation has been accepted for inclusion in WVU Graduate Theses, Dissertations, and Problem Reports collection by an authorized administrator of The Research Repository @ WVU.

For more information, please contact researchrepository@mail.wvu.edu. 


\title{
Synthesis of Benzocarbazoles, Indoloquinolines and Indolonaphthridines from Thermolysis of Benzoenynyl Ketenimines and Carbodiimides
}

\section{Chongsheng Shi}

\author{
Dissertation Submitted to \\ The Eberly College of Arts and Sciences \\ at West Virginia University \\ in partial fulfillment of the requirements \\ for the degree of
}

\author{
Doctor of Philosophy \\ in \\ Organic Chemistry
}

\author{
Kung K. Wang, PH. D., Chair \\ Björn Söderberg, Ph. D. \\ Jeffrey L. Petersen, Ph. D. \\ Peter M. Gannett, Ph. D. \\ Harry O. Finklea, Ph. D. \\ Department of Chemistry \\ Morgantown, West Virginia \\ 2001
}

Keywords: Benzocarbazoles, Indoloquinolines, Indolonaphthridines, Benzoenynyl Ketenimines, Benzoenynyl Carbodiimides 


\title{
ABSTRACT \\ Synthesis of Benzocarbazoles, Indoloquinolines and Indolonaphthridines from Thermolysis of Benzoenynyl Ketenimines and Carbodiimides
}

\begin{abstract}
Chongsheng Shi
The development of a general route to the $N$-[2-(1-alkynyl)phenyl]ketenimines (enyne-ketenimines) and $N$-[2-(1-alkynyl)phenyl]carbodiimides (enyne-carbodiimides) and their subsequent thermal behavior are described. Like enyne-allene and enyneketene systems, these enyne-hetereocumulenes undergo cycloaromatization through two competing biradical mechanisms under thermal conditions and therefore could serve as potential DNA cleaving agents. The resultant nitrogen-containing hetereocyclic compounds are also biologically interesting. The research described herein provides a easy access to the synthesis of benzo[ $b]$ carbazole, indoloquinoline and indolonaphthyridine alkaloids. In addition, the new synthetic strategies for these compounds are very versatile, providing access to a diverse array of analogs of these alkaloids.
\end{abstract}




\section{DEDICATION}

To my wife, Lingyun, and daughter, Yi. 


\section{ACKNOWLEDGMENT}

The author would like to express his sincere appreciation to his research advisor, Dr. Kung K. Wang. Dr. Wang has served as a dedicated teacher, inspiring mentor, and patient advisor. The completion of the work described herein would have been impossible without his extraordinary assistance.

Much appreciation is also extended to the research committee members, Drs. Björn Söderberg, Peter M. Gannett, Jeffrey L. Petersen and Harry O. Finklea for their constructive comments and the many hours of fruitful conversation involving the chemistry during the whole course.

Appreciation also goes to Dr. William R. Moore for his constant encouragement and priceless help. The author would also like to thank Drs. Gabor B. Fodor, Chester W. Muth, Katharine J. Covert, and Debra L. Mohler for their helpful suggestions and noteworthy ideas to his future career development. The members in Dr. Wang's research group, the entire staff and friends in the Department of Chemistry deserve recognition for their friendship and help in a variety of ways. The collective richness of personality, knowledge, and skill that graces the Department of Chemistry made the author's stay in Morgantown both exciting and enjoyable.

Financial support in the form of research assistantship from the National Science Foundation and teaching assistantship from the Department of Chemistry at WVU are gratefully acknowledged.

The author also thanks his wife, Lingyun, and his daughter, Yi, who constantly provide a wonderful and supportive family environment for his scholarly pursuits. 


\section{TABLE OF CONTENTS}

Title page $\quad$ i

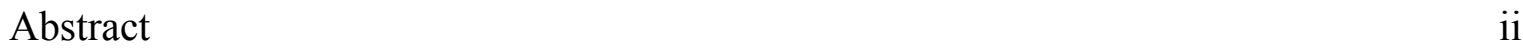

Dedication $\quad$ iii

Acknowledgments $\quad$ iv

Table of Contents $\quad$ V

List of Tables $\quad \mathrm{x}$

List of Figures $\quad$ X

List of Schemes $\quad$ xi

Synthesis of Benzocarbazoles, Indoloquinolines and Indolonaphthridines from

Thermolysis of Benzoenynyl Ketenimines and Carbodiimides

1. Introduction 1

1.1 Background of the Biradical-Forming Cycloaromatizations 1

$\begin{array}{ll}1.2 \text { Research Objectives } & 7\end{array}$

2. Literature Survey for the Synthesis of Enyne-Ketenimines and

Enyne-Carbodiimides and the Related Cycloaromatization Reactions 9

2.1 Competing Pathways for the Cycloaromatization Reactions 9

2.2 Methods for the Synthesis of Ketenimines 12

2.2.1 Synthesis of Ketenimines by Dehydration of Secondary Amides 12

2.2.2 Synthesis of Ketenimines by Dehydrohalogenation of Imidoyl Halides $\quad 13$

2.2.3 From Ketenes and Iminophosphoranes 14

2.2.4 From Phosphorus Ylides and Isocyanates or Related Compounds 15 
2.3 Methods for the Synthesis of Carbodiimides

2.3.1 Dehydration of Ureas

2.3.2 Elimination of Hydrogen Sulfide from Thioureas

2.3.3 Aza-Wittig Reactions of Iminophosphoranes with Isocyanates or Isothiocyanates

3. Results and Discussion

3.1 Generation of Biradicals and Subsequent Formation of Quinolines and $5 H$-Benzo $[b]$ carbazoles from $N$-[2-(1-Alkynyl)phenyl]ketenimines

3.1.2 Results and Discussion

3.1.3 Summary

3.2 Biradicals from Thermolysis of $N$-[2-(1-Alkynyl)phenyl]- $N$ 'phenylcarbodiimides and Their Subsequent Transformations to $6 H$-Indolo[2,3-b]quinolines

3.2.1 General Strategy

3.2.2 Results and Discussion

3.2.3 Summary

3.3 Synthesis of $6 H$-Indolo[2,3-b][1,6]naphthyridines and Related Compounds as the 5-Aza Analogues of Ellipticine Alkaloids 
$\begin{array}{ll}\text { 6. References } & 70\end{array}$

$\begin{array}{ll}\text { 7. Appendix } & 81\end{array}$

$\begin{array}{lr}\text { Publications } & 82\end{array}$

\section{LIST OF TABLES}

Table 1. Tentative Chemical-Shift Assignments of NMR Spectra of 106d 30

Table 2. Tentative Chemical-Shift Assignments of NMR Spectra of 109d 31

Table 3. Tentative Chemical-Shift Assignments of NMR Spectra of 131d 40

Table 4. Tentative Chemical-Shift Assignments of NMR Spectra of 169 45

Table 5. Tentative Chemical-Shift Assignments of NMR Spectra of 170 46

\section{LIST OF FIGURES}

Figure 1. Structures of Enediyne Antitumor Antibiotics 1-6 1

Figure 2. Two Types of Enyne-Ketenimines $\mathbf{1 0 0}$ and $\mathbf{1 0 1} 20$

Figure 3. A Plot of - ln A versus Reaction Time (hr) in the Case of 104a 23

Figure 4. The Nonbonded Steric Interactions in 105b 23

Figure 5. The Nonbonded Steric Interactions in the Diels-Alder Reaction 24

Figure 6. A Plot of $\ln \mathrm{C}_{0} / \mathrm{C}$ versus Reaction Time (hr) in the Case of 104b 25

Figure 7. A Plot of $\ln \mathrm{C}_{0} / \mathrm{C}$ versus Reaction Time (hr) in the Case of 104c 25

Figure 8. A Plot of $\ln \mathrm{C}_{0} / \mathrm{C}$ versus Reaction Time (hr) in the Case of 104d 26

$\begin{array}{lr}\text { Figure 9. Numbering of 103a } & 29\end{array}$

Figure 10. Numbering of 106d 30

Figure 11. Numbering of 109d 31

Figure 12. Numbering of 126d 39 
$\begin{array}{ll}\text { Figure 14. Structure Comparison } & 41\end{array}$

$\begin{array}{ll}\text { Figure 15. Numbering of } \mathbf{1 6 9} & 45\end{array}$

Figure 16. Numbering of $\mathbf{1 7 0}$

\section{LIST OF SCHEMES}

Scheme 1. Observations by Masamune et al. 2

Scheme 2. The Bergman Cycloaromatization Reaction 2

Scheme 3. Mechanism of DNA Cleavage by Calicheamicin $\gamma^{1}{ }_{1}^{1}$

Scheme 4. Mechanism of DNA Cleavage by NCS Chromophore 6

Scheme 5. The Myers Cycloaromatization Reaction 4

Scheme 6. Saito's Study Related to NCS 4

Scheme 7. Systems for the Biradical-Forming Reactions 5

$\begin{array}{lr}\text { Scheme 8. The Moore Cyclization } & 5\end{array}$

Scheme 9. The Unexplored Conjugated Enyne-Heterocumulene Systems 6

$\begin{array}{ll}\text { Scheme 10. Wang's Early Attempts to Generate Biradical } 34 & 6\end{array}$

$\begin{array}{ll}\text { Scheme 11. Studies about the 2,5-Didehydropyridine Biradicals } & 7\end{array}$

Scheme 12. The Resonance Structures of the Ketenimines 8

$\begin{array}{ll}\text { Scheme 13. A Competing Pathway to the Moore Cyclization } & 10\end{array}$

$\begin{array}{ll}\text { Scheme 14. An Alternative Pathway to the Myers-Saito Cycloaromatization } & 10\end{array}$

$\begin{array}{ll}\text { Scheme 15. Observations by Gillmann and Co-workers } & 11\end{array}$

Scheme 16. The Bestmann Method for the Dehydration of Secondary Amides 13

$\begin{array}{lr}\text { Scheme 17. Observations by Differding and Ghosez } & 13\end{array}$

Scheme 18. Dehydration of Secondary Amides Using $\mathrm{PCl}_{5}$ 
Scheme 19. Reactions of $N$-(2-Pyridyl)Ketenimine 73

$\begin{array}{ll}\text { Scheme 20. The Rearrangement of the Bataine Intermediates } & 16\end{array}$

$\begin{array}{ll}\text { Scheme 21. Reactions of } N \text {-Phenyl-N'-(2-Pyridyl)Carbodiimides } 93 & 18\end{array}$

$\begin{array}{ll}\text { Scheme 22. Dimerization of the Mixed Carbodiimides } & 19\end{array}$

$\begin{array}{ll}\text { Scheme 23. Retrosynthetic Analysis } & 21\end{array}$

Scheme 24. Thermolysis of Enyne-Ketenimine 104 22

$\begin{array}{ll}\text { Scheme 25. Schmittel's Observation } & 27\end{array}$

Scheme 26. One Pot Reactions Involving Ketenimine Intermediates 27

Scheme 27. Synthesis of $5 H$-Benzo[ $b]$ carbazole 28

Scheme 28. Thermolysis of Enyne-carbodiimide 126 33

Scheme 29. Molina's Synthesis of 131a 34

$\begin{array}{ll}\text { Scheme 30. Thermolysis of Enyne-Carbodiimide 126g } & 37\end{array}$

$\begin{array}{ll}\text { Scheme 31. Thermolysis of 143b } & 37\end{array}$

$\begin{array}{ll}\text { Scheme 32. Thermolysis of } \mathbf{1 4 3 h} & 38\end{array}$

$\begin{array}{ll}\text { Scheme 33. Proposed Structure of } \mathbf{1 4 4} & 38\end{array}$

Scheme 34. Synthesis of 5,11-Dimethyl-5H-indolo[2,3-b][1,6]naphthyridine 42

Scheme 35. Thermolysis of Benzoenynyl Carbodiimides 165

Scheme 36. Synthesis of Indolonaphthyridine 170 44

Scheme 37. Potential Applications in the Synthesis of Benzo[f]pyridoindoles and Pyridopyrroloquinolines 


\section{Introduction}

\subsection{Background of the Biradical-Forming Cycloaromatizations}

The biradical-forming cycloaromatization reactions have attracted considerable attention in recent years. ${ }^{1,2}$ This is due mainly to the discovery of several very potent antitumor antibiotics such as calicheamicins $\mathbf{1},{ }^{3}$ esperamicins $2,{ }^{4}$ dynemicin $3,{ }^{5} \mathrm{C}-1027$ chromophore $4,{ }^{6}$ kedarcidin $\mathbf{5},{ }^{7}$ and neocarzinostatin (NCS) chromophore $\mathbf{6},{ }^{8}$ which cleave DNA via generation of biradicals under mild conditions (Figure 1). Among these thermally-induced biradical-forming reactions,
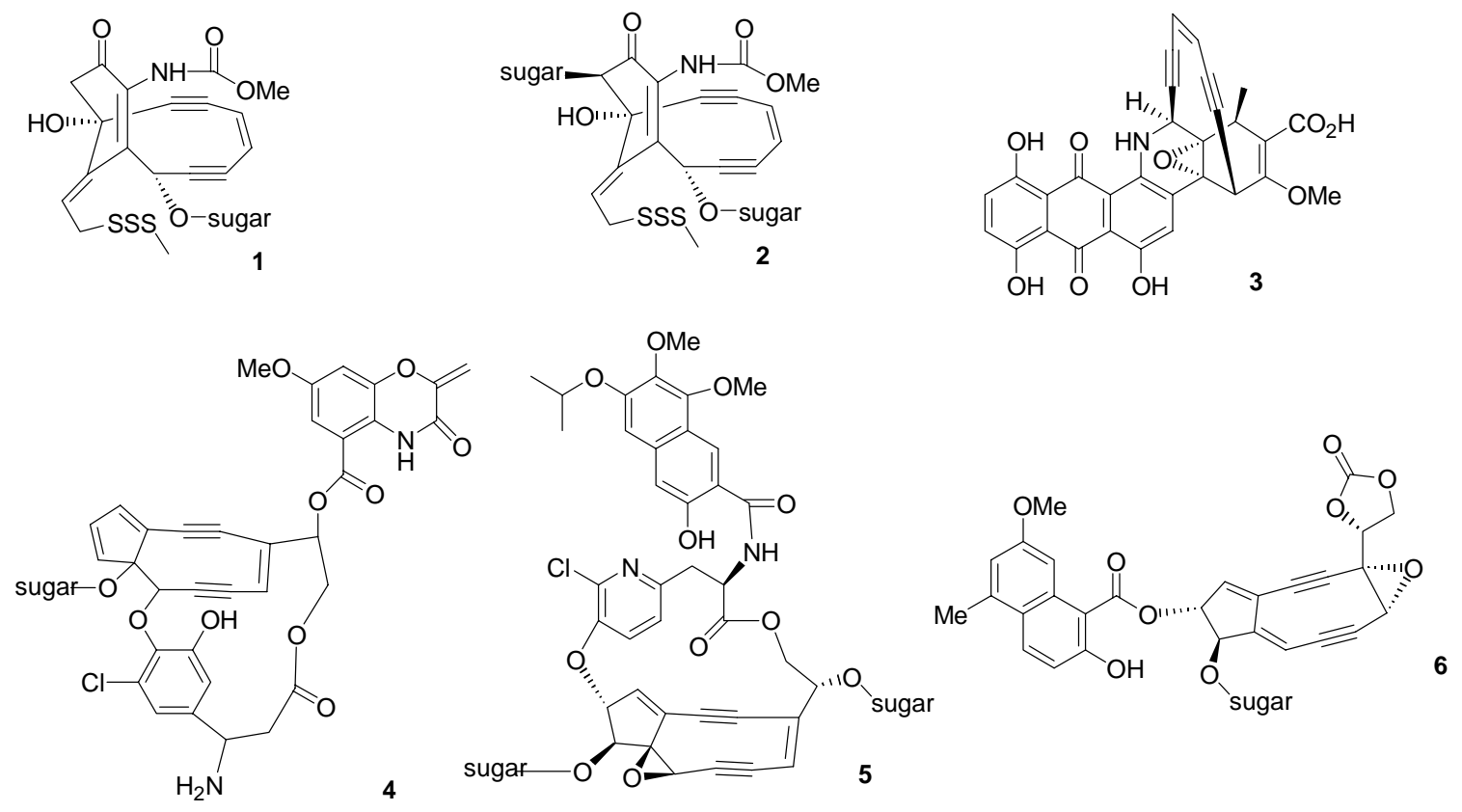

Figure 1. Structures of Enediyne Antitumor Antibiotics 1-6.

the Bergman cyclization of (Z)-3-hexene-1,5-diynes (enediynes) to 1,4-didehydrobenzenes and the Myers cyclization of (Z)-1,2,4-heptatrien-6-ynes (enyne-allenes) to $\alpha, 3$-didehydrotoluenes have been investigated extensively. ${ }^{9,10}$ 
As for as enediyne cyclization, in 1971, Masamune et al. reported the conversion of the two cyclic enediynes (7 and 10) into the corresponding benzenoid systems (9 and 12), but they did not mention the involvement of a biradical intermediate in the process (Scheme 1). ${ }^{11}$

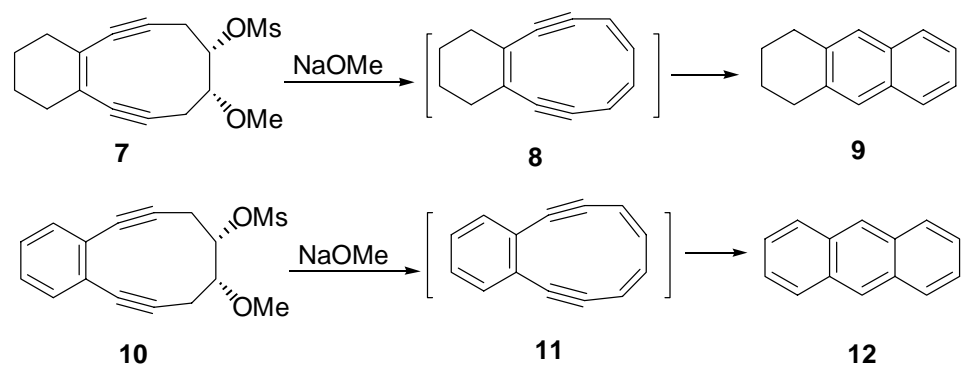

Scheme 1. Observations by Masamune et al. Ms = mesyl

The cycloaromatization of endiynes via the 1,4-didehydrobenzene biradicals was clearly demonstrated with the elegantly designed studies by Bergman in 1972 (Scheme 2). ${ }^{\text {a }}$

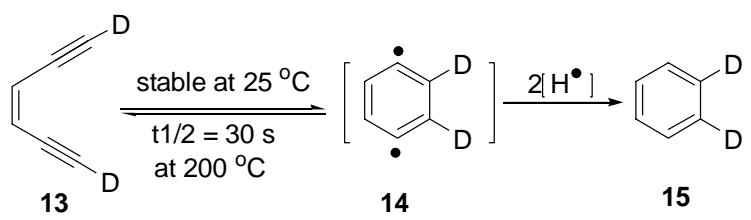

Scheme 2. The Bergman Cycloaromatization Reaction.

It was in 1987 that the enediyne chemistry did arouse much interest in chemical community when two very potent naturally occurring antitumor antibiotics, calicheamicins (1) and esperamicins (2) bearing an enediyne moiety, were discovered by researchers from the Lederle Laboratories ${ }^{3}$ and Bristol-Myers ${ }^{4}$, respectively. In the proposed mechanisms for DNA cleavage by these enediyne antibiotics, the 1,4-benzenoid biradicals generated by the Bergman cyclization attack DNA deoxyribose by hydrogen atom abstraction (Scheme 3$).{ }^{1 \mathrm{~d}}$ A nucleophile attacks the middle sulfur atom of the trisulfide group in $\mathbf{1}$. The resulting thiolate reacts with the $\alpha, \beta$-unsaturated ketone intramolecularly to give the corresponding addition product $\mathbf{1 6}$. The 
biradical $\mathbf{1 7}$ produced from the following Bergman cyclization reaction of $\mathbf{1 6}$ cleaves DNA by abstracting two hydrogen atoms, giving 18 .
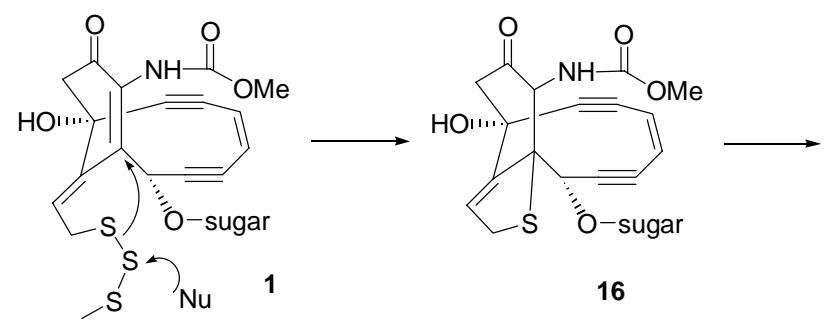

16

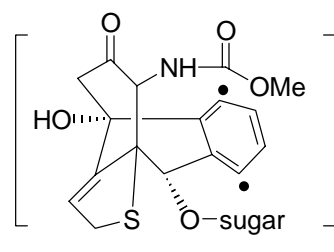

17

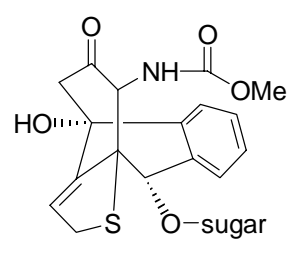

18

Scheme 3. Mechanism of DNA Cleavage by Calicheamicin $\gamma_{1}^{1} 1$.

It is believed that the NCS chromophore 6 causes DNA damage in a similar way (Scheme 4). ${ }^{12}$ According to the hypothesis, a nucleophile stereospecifically attacks at $\mathrm{C} 12$, resulting in the ring skeleton rearrangement with epoxide opening and formation of the highly strained and labile cyclic enyne-cumulene 19. The 3,7-dehydroindene derivative $\mathbf{2 0}$ formed from the very reactive intermediate 19, which rapidly undergoes cycloaromatization, proceeds to attack DNA by hydrogen abstraction, resulting in the formation of $\mathbf{2 1}$.

The involvement of the biradical 20 in the action of the NCS chromophore $\mathbf{6}$ was demonstrated with the parent (Z)-1,2,4-heptatrien-6-yne (22) by Myers and co-workers in 1989. This cycloaromatization leads to toluene (24) via $\alpha, 3$-didehydrotoluene (23) by hydrogen atom abstraction from 1,4-cyclohexadiene (1,4-CHD) (Scheme 5). ${ }^{10 a} \mathrm{~A}$ fundamental distinction between the 3,7-dehydroindene derivative $\mathbf{2 0}$ and the putative $\alpha, 3$-didehydrotoluene species $\mathbf{2 3}$ is that the former is almost certainly constrained as a $\sigma$-radical pair, while the latter is a $\sigma, \pi$ biradical capable of full benzylic resonance. 


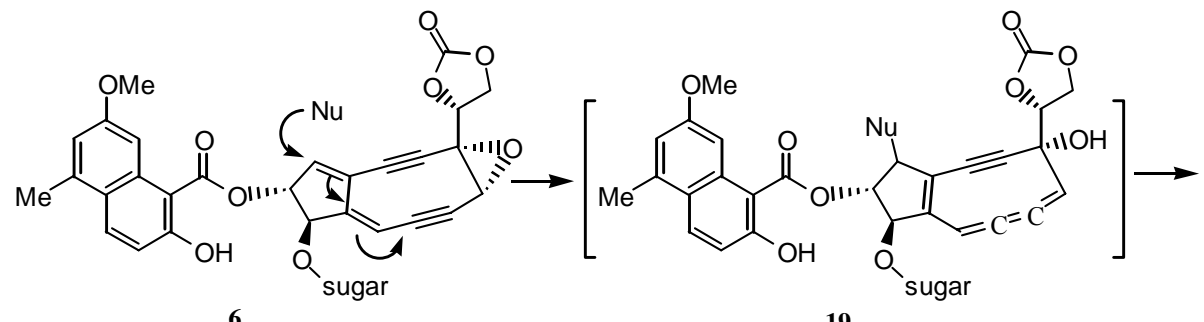

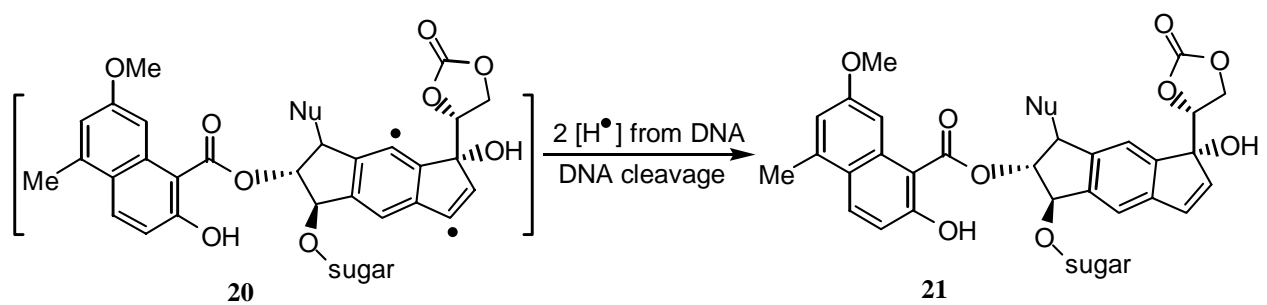

Scheme 4. Mechanism of DNA Cleavage by the NCS Chromophore 6.

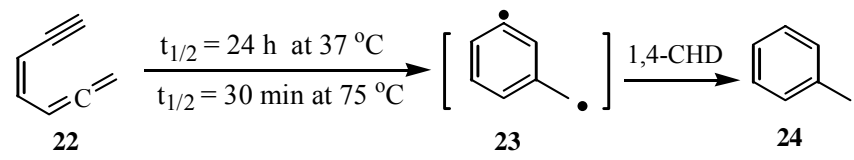

Scheme 5. The Myers Cycloaromatization Reaction.

Similarly, Saito and co-workers also demonstrated independently that the enyne-allene system 26 with a substituent at C-3 position undergoes facile cycloaromatization to produce biradical species $\mathbf{2 7}$, which mimics to some extent the action of neocarzinostatin and causes clean scission of double stranded DNA at $37^{\circ} \mathrm{C}$ in the absence of any additives (Scheme 6). ${ }^{10 c, 10 \mathrm{~d}}$

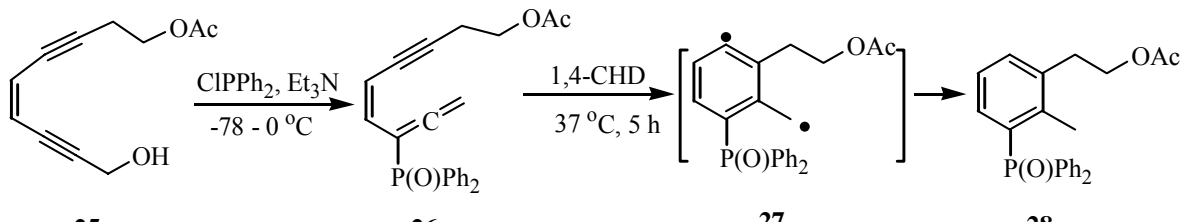

Scheme 6. Saito's Study Related to the NCS.

Because the naturally occuring enediyne antibiotics still rank amongst the most potent antitumor agents known so far, it is therefore not surprising that many choices of various 
precursors which can lead to the characteristic biradical intermediates have been used to mimic the DNA-cleaving ability of these enediyne antibiotics. Some basic systems that are widely used for the model studies of enediyne prodrugs are listed in Scheme 7..$^{1 \mathrm{c}, 9 \mathrm{~b}, 10 \mathrm{~b}, 10 \mathrm{c}, 10 \mathrm{~d}, 13,14,15}$ In addition to parent system, each of the unsaturated groups in the (Z)-enediynes could be substituted with an isoelectronic group.



Scheme 7. Systems for the Biradical-Forming Reactions.

Moore and co-workers successfully incorporated an oxygen atom into the conjugated enyne-allene systems with a very imaginative and skillful choice of "masked" enyne-ketene precursors. Similarly, the Moore cyclization of enyne-ketenes provides easy access to biradicals having an aryl and a phenoxy radical center. ${ }^{16}$ For example, thermolysis of 4alkynylcyclobutenone 29 in acetonitrile gave the quinone 32 (Scheme 8 ). ${ }^{13 \mathrm{~b}}$ The reaction is believed to proceed through an electrocyclic ring opening of $\mathbf{2 9}$ to form the enyne-ketene $\mathbf{3 0}$.



Scheme 8. The Moore Cyclization. 
The highly reactive $\mathbf{3 0}$ then undergoes a Moore cyclization to give the biradical 31, which in turn leads to $\mathbf{3 2}$ via an intermolecular hydrogen-atom transfer.

As for the conjugated enyne-heterocumulenes, while several synthetic pathways to enyne-ketenes and their versatility as reactive intermediates have been reported, the biradicalforming reactions involving other hetero atoms in the conjugated systems such as enyneketenimines, enyne-carbodiimides, enyne-isocyanates, and enyne-thioisocyanates remained virtually unexplored (Scheme 9). Compounds with these heteroanalogous functionalities might prove to be viable medicinal agents and useful biological probes.



Scheme 9. The Unexplored Conjugated Enyne-Heterocumulene Systems.

In an effort toward demonstrating the use of a nitrile group as a substituent for the alkynyl group of enyn-allenes, compound $\mathbf{3 3}$ was synthesized. However, attempts to generate biradical $\mathbf{3 4}$ and subsequently 2 -isopropylpyridine $\mathbf{3 5}$ by thermolysis of $\mathbf{3 3}$ containing an excess of 1,4-CHD as a hydrogen-atom donor were unsuccessful (Scheme 10). ${ }^{17 a}$

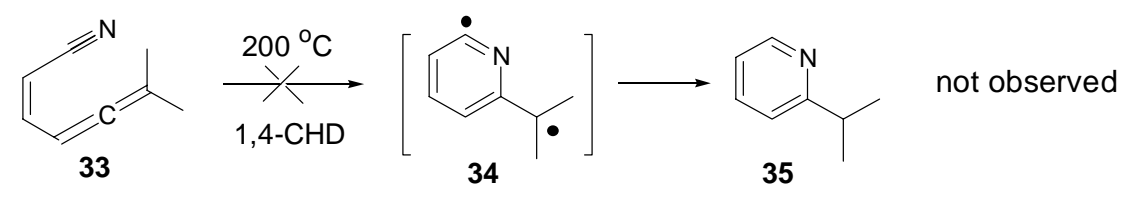

Scheme 10. Wang's Early Attempts to Generate the Biradical 34.

A similar attempt to involve the nitrile group in a biradical-forming reaction also failed. ${ }^{17 b}$ Interestingly, when $C, N$-dialkynyl imines $\mathbf{3 6}$ were heated in refluxing benzene, enynyl 
nitriles 38 were produced in excellent yields presumably through the putative 2,5didehydropyridines $\mathbf{3 7}$, which could not be captured by $1,4-\mathrm{CHD}$ or, in the case of $\mathbf{3 8 \mathbf { b }}$, by the carbon-carbon double bond intramolecularly (Scheme 11). ${ }^{18 a}$ Recently, it was observed that very small amount of 37a could be captured to produce 2-methyl-4,5-diphenylpyridine when the reaction was conducted in the presence of moderate amounts of a protic acid $\left(\mathrm{HBF}_{4}\right){ }^{18 b}$

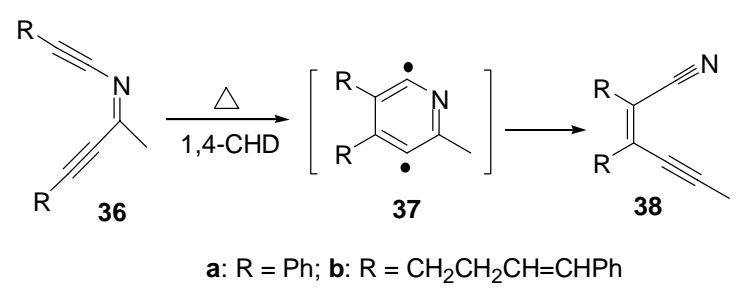

Scheme 11. Studies about the 2,5-Didehydropyridine Biradicals.

\subsection{Research Objectives}

Although only a trace amount of putative 2,5-didehydropyridines $\mathbf{3 7} \mathbf{a}^{18 \mathrm{~b}}$ are trapped in the presence of a protic acid $\left(\mathrm{HBF}_{4}\right)$, the high-yielding conversions of $C, N$-dialkynyl imines 36 to $(Z)-\beta$-alkynylacrylonitriles $\mathbf{3 8}$ under mild thermal condition ${ }^{18 a}$ are in good agreement with the proposed mechanism of the aza-Bergman rearrangement as depicted in Scheme 11. We reasoned that the radical site at the ortho position of $\mathrm{N}$-atom involving pyridine biradicals might be the cause of pyridine ring opening, leading to the nitriles. However, the enyne-azacumulene systems could avoid this problem. As a part of our continuing efforts in the study of enyne-allene chemistry, we envisioned that enyne-ketenimines having a nitrogen atom in the conjugated system and enyne-carbodiimides having two nitrogen atoms in the conjugated system could serve as precursors for the generation of biradicals via cyclization reaction similar to enyneallenes and enyne-ketenes. The resulting biradicals from cycloaromatization of enyneketenimines and enyne-carbodiimides could also behave as potentially potent DNA cleaving 
agents and find applications for the synthesis of biologically interesting alkaloids, such as quinolines, benzocarbazoles, indoloquinolines, indolonaphthridines, benzopyridoindoles, and pyridopyrroloquinolines. Unlike allenes and ketenes, ketenimines have three major resonant structures: the 1-azaallene form 39a, and the zwitterionic forms $39 \mathbf{b}$ and $39 \mathbf{c}$ as outlined in Scheme 12. The nucleophilicity of the $\beta$-carbon atom and the electrophilicity of the central carbon atom may play a different role in the reaction.

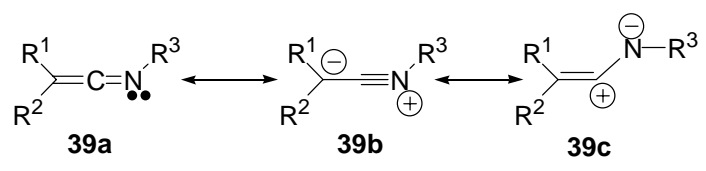

Scheme 12. The Resonance Structures of Ketenimines.

The objectives of this research are: (i) to develop a new biradical forming reaction system; (ii) to synthesize and isolate enyne-ketenimines and enyne-carbodiimides; (iii) to investigate the general thermal behaviors, the influence of the substituents at the alkyne terminus in the conjugated systems on the cyclization mode and the relevant mechanisms of enyneketenimines and enyne-carbodiimides; (iv) to exploit a new efficient route to the synthesis of quinolines and $5 \mathrm{H}$-benzo[b]carbazoles by intermolecular and/or intramolecular trapping the biradicals produced from thermolysis of the corresponding benzoenynyl ketenimines; and (v) to develop a convenient and flexible methodology for the synthesis of 2-aminoquinolines, $6 \mathrm{H}$ indolo[2,3-b]quinolines and indolonaphthyridines by intermolecular and/or intramolecular trapping the biradicals produced from thermolysis of the corresponding benzoenynyl carbodiimides. 


\section{Literature Survey for the Synthesis of Enyne-Ketenimines and Enyne-Carbodiimides and the Related Cycloaromatization Reactions}

\subsection{Competing Pathways for the Cycloaromatization Reactions}

To begin this research, it is instructive to first consider the extensive research efforts in this area by other groups. Since the disclosure of the biradical-forming mechanisms of the Bergman and the Myers reactions, the research interests on the thermal cycloaromatization of enediynes, enyne-cumulenes, enyne-allenes and enyne-ketenes have been focused on the synthesis of model compounds to mimic the naturally-occuring enediyne antibiotics as well as on the utilization of the biradical cyclization for the construction of polycyclic compounds by the intramolecular trapping strategies. ${ }^{1 a}$ Furthermore, the attention was drawn on the influence of the substituents at the alkyne terminus in the conjugated systems on the cyclization mode and on the further exploitation of the new alternative pathways for synthetic and biological applications.

In 1989, the Moore group reported that the enyne-ketenes could undergo two competing routes to produce two different biradicals for the ring closure. ${ }^{19}$ For example, treatment of dimethyl squarate 40 with 1-lithio-1-hexyne followed by quenching the reaction mixture with ammonium chloride furnished cyclobutenone 41a. Thermolysis of 41a in refluxing $p$-xylene gave the 1,4-benzoquinone $\mathbf{4 4 a}$ as the sole product (Scheme 13). The reaction is considered to proceed through a stereoselective ring opening of 41a in which the electron-donating hydroxyl group rotates outward to give the $\mathrm{Z}$ geometric enyne-ketene $42 \mathbf{a}^{19}$ Subsequent cycloaromatization to form biradical $\mathbf{4 3}$ followed by an intermolecular or intramolecular hydrogen-atom transfer process results in the formation of 44a. ${ }^{13 b, 20}$ When the R group is phenyl, the enyne-ketene $\mathbf{4 2 b}$ also undergoes a competing ring closure to form the five- 
membered ring biradical $\mathbf{4 5}$ in which the phenyl group stablizes the adjacent vinyl radical. As a result, a mixture of $44 \mathrm{~b}$ and $\mathbf{4 6 b}$ was produced from $41 \mathrm{~b}$.
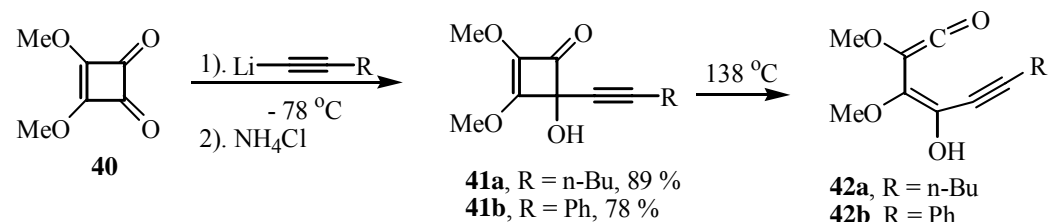

42a, $\mathrm{R}=\mathrm{n}-\mathrm{Bu}$

41b, $\mathrm{R}=\mathrm{Ph}, 78 \%$

42b, $\mathrm{R}=\mathrm{Ph}$,

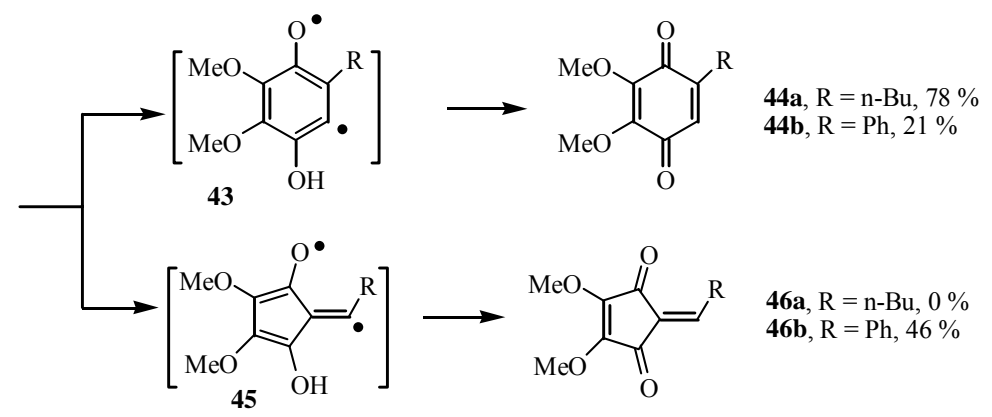

Scheme 13. A Competing Pathway to the Moore Cyclization.

The Schmittel group discovered an alternative $\mathrm{C}^{2}-\mathrm{C}^{6}$ cyclization pathway which replaces the well-known $\mathrm{C}^{2}-\mathrm{C}^{7}$ Myers-Saito cycloaromatization when an aryl substituent is attached at the alkyne terminus in the enyne-allene system (Scheme 14). ${ }^{21}$ The enyne-allenes 47a-d were heated

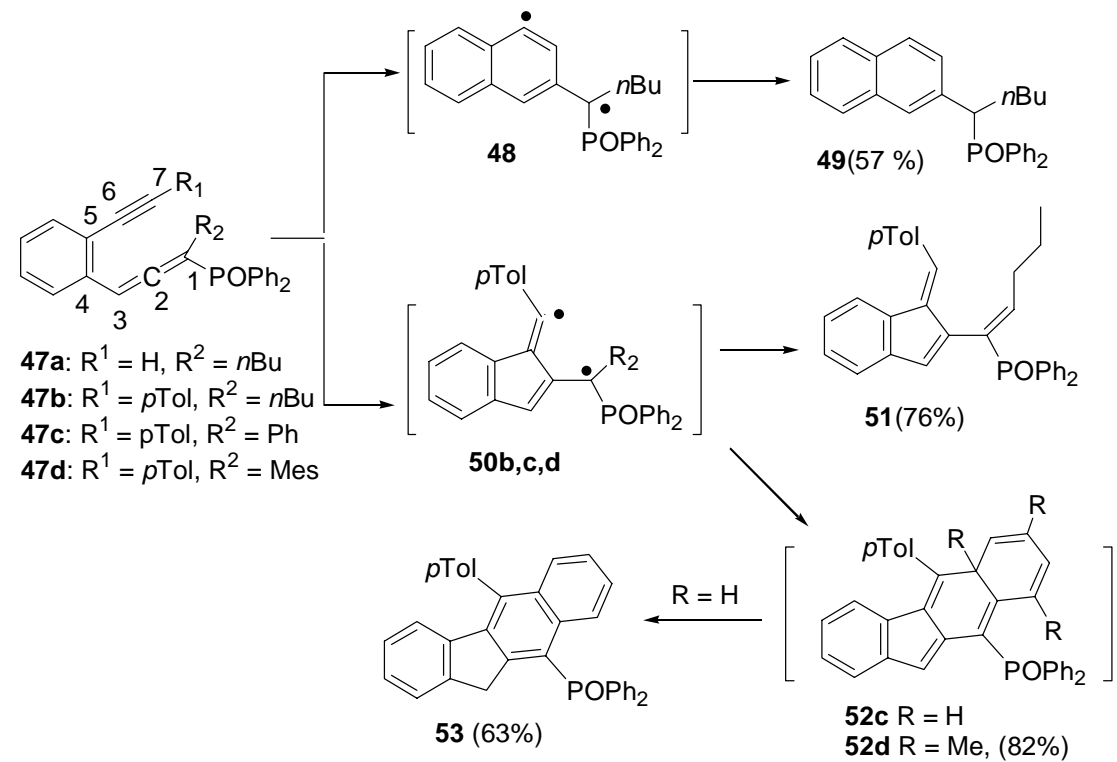

Scheme 14. An Alternative Pathway to the Myers-Saito Cycloaromatization. 
with an excess of 1,4-CHD as hydrogen-atom donor in toluene. Compound 47a gave the $\mathrm{C}^{2}-\mathrm{C}^{7}$

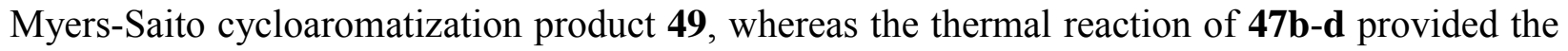
$\mathrm{C}^{2}-\mathrm{C}^{6}$ cyclization products $\mathbf{5 1}, \mathbf{5 2 d}$ and $\mathbf{5 3} .^{21}$

Although they were not able to trap the postulated biradical $\mathbf{5 0}$ by an intermolecular reaction $\left(\mathrm{O}_{2}, \mathrm{PhSH},\left(\mathrm{Me}_{3} \mathrm{Si}\right)_{3} \mathrm{SiH}, 1,4-\mathrm{CHD}, 2,2,6,6\right.$-tetramethylpiperidine $\mathrm{N}$-oxide $){ }^{22}$ they could exclude a zwitterion as an alternative intermediate because the rates of the transformations of the formal ene reaction $\mathbf{4 7 b} \rightarrow \mathbf{5 1}$ and the Diels-Alder reaction $\mathbf{4 7 c - d} \rightarrow \mathbf{5 2}$ were not affected by the change from a non-polar solvent (mesitylene or benzene) to a very polar solvent, such as DMSO. The very similar activation data for the formal ene reaction $(\mathbf{4 7 b} \rightarrow \mathbf{5 1})$ and the DielsAlder reaction $(\mathbf{4 7 c - d} \rightarrow \mathbf{5 2})$ and the almost identical activation energies for the formal DielsAlder reactions of $\mathbf{4 7} \mathbf{c}$ and $\mathbf{4 7} \mathbf{d}$ supported the proposed stepwise biradical mechanism instead of the concerted ene reaction or the Diels-Alder reaction. The activation energy of $\mathbf{4 7 d}$ would be expected to be much higher than that of $\mathbf{4 7 c}$ because of the steric effect of the bulky mesityl group. Moreover, intramolecular vinyl radical cyclizations onto the aromatic rings are well documented. $^{23}$

Gillmann and co-workers also independently reported their observation of the new behavior of enyne-allenes (Scheme 15). Thermolysis of enyne-allene ester $\mathbf{5 4}$ in chlorobenzene

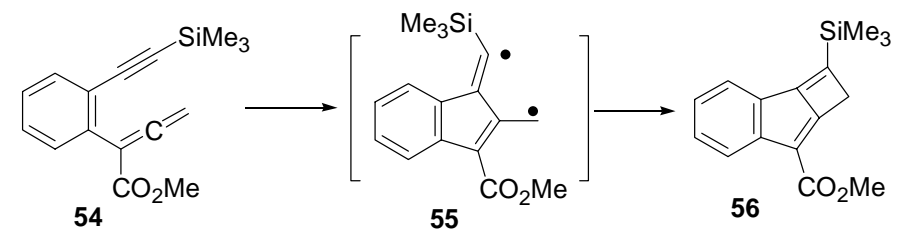

Scheme 15. Observations by Gillmann and Co-workers. 
in the presence of 1,4-CHD gave the tricyclic $1 H$-cyclobuta[a]indene 56 in $62 \%$ yield. The 1silylvinyl radical $\mathbf{5 5}$ was proposed to be the intermediate in the process, but a polar mechanism involving a 1-silylvinyl carbenium ion could not be ruled out. ${ }^{24}$

The methods for preparation of enyne-ketenimines and enyne-carbodiimides are rarely recorded in literature. ${ }^{25}$ No isolated enyne-ketenimines or enyne-carbodiimides was reported when we started this project. To the best of our knowledge, only one example regarding the reaction of enyne-ketenimine was reported in the literature. ${ }^{25 a}$ Introduction of the ketenimine and carbodiimide functionalities in conjugation with the enyne system is obviously a key step. There are many synthetic methods reported in the literature for ketenimines and carbodiimides. ${ }^{26}$ The following is a brief review of the methods for the preparation of ketenimines and carbodiimides.

\subsection{Methods for the Synthesis of Ketenimines}

\subsubsection{Synthesis of Ketenimines by Dehydration of Secondary Amides}

Synthesis of ketenimines by dehydration of secondary amides is a general method that was introduced in 1964 by Stevens and Singhal. ${ }^{27}$ Originally, phosphorus pentoxide was employed as dehydrating reagent and Florisil or sand was used to facilitate stirring and to accelerate the reaction. Pyridine or triethylamine was used as solvent. Later, Bestmann and coworkers introduced the use of dibromotriphenylphosphorane (prepared in situ from triphenylphosphine and bromine) as the dehydrating reagent and provided convenient access to trisubstituted ketenimines under mild reaction conditions. ${ }^{28 a}$ The putative intermediate in this reaction is $\mathbf{5 8}$. It is conceivable that the ketenimine $\mathbf{6 0}$ was produced from the dehydrobromonation of the imidoyl bromide $\mathbf{5 9}$ which was formed from $\mathbf{5 8}$ (Scheme 16). 


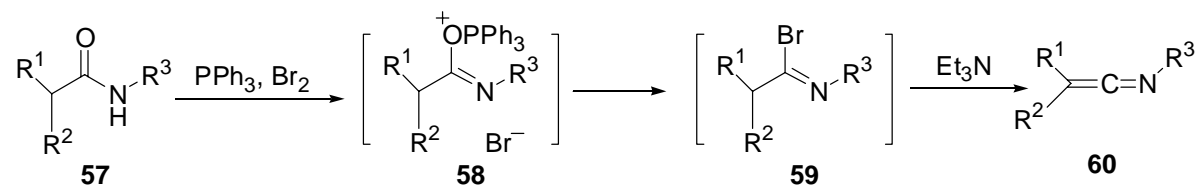

Scheme 16. The Bestmann Method for the Dehydration of Secondary Amides.

Differding and Ghosez made the carbazole 64 by treatment of the anilide 61 with $\mathrm{Ph}_{3} \mathrm{PBr}_{2}$ in the presence of triethylamine in refluxing $\mathrm{CH}_{2} \mathrm{Cl}_{2}$ (Scheme 17). ${ }^{25 \mathrm{a}}$ In the proposed mechanism, the vinylketenimine 62 acts as electron-rich dienes in the Diels-Alder reaction. The adduct 63 undergoes tautomerization to give $\mathbf{6 4}$ under the reaction conditions. In fact, this is the only reported example involving enyne-ketenimines.

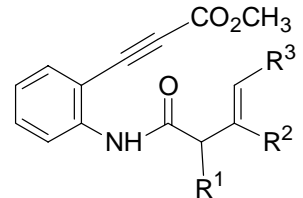

61

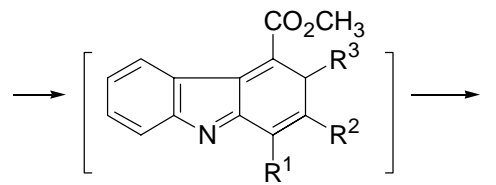

63



62

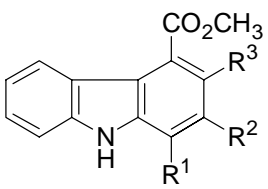

64

Scheme 17. Observations by Differding and Ghosez.

A different variation uses dichlorotriphenylphosphorane, prepared in situ from triphenylphosphine and tetrachloromethane, as the dehydration agent. ${ }^{28 \mathrm{~b}}$

\subsubsection{Synthesis of Ketenimines by Dehydrohalogenation of Imidoyl Halides}

This frequently used method for the preparation of ketenimines was introduced by Stevens and French in $1954 .^{29}$ Treatment of the secondary amides 57 with phosphorus pentachloride in refluxing benzene gave the imidoyl chloride $\mathbf{6 5}$ as isolatable intermediate in most cases. When $\mathbf{6 5}$ was treated with triethylamine, dehydrochlorination occurred to afford the 
ketenimine $\mathbf{6 0}$ (Scheme 18). This method is suitable for the preparation of the trialkyl ketenimines and ketenimines bearing chiral substituents on nitrogen. For example, the ketenimine $\mathbf{6 7}$ was obtained from the penicillin derivative $\mathbf{6 6}$ using this method (eq 1). ${ }^{30}$

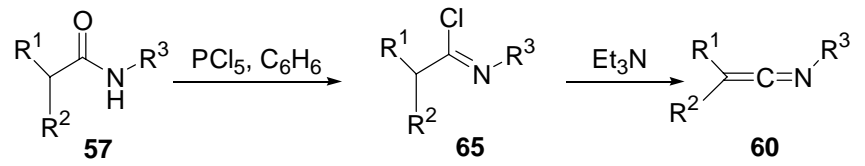

Scheme 18. Dehydration of Secondary Amides Using $\mathrm{PCl}_{5}$.

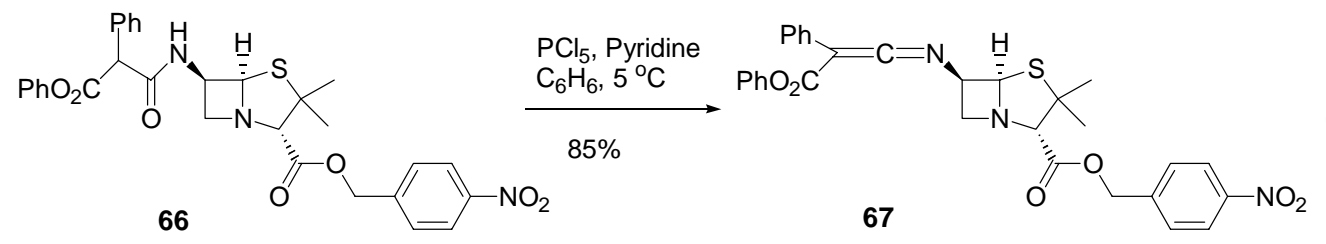

\subsubsection{From Ketenes and Iminophosphoranes ${ }^{31}$}

In the early 1920s, Staudinger and co-workers prepared ketenimines by the reaction of iminotriphenylphosphorane $\left(\mathrm{Ph}_{3} \mathrm{P}=\mathrm{NR}, N, P\right.$-ylide $)$ with ketenes under mild conditions. This method is especially useful for the preparation of the thermally labile ketenimines. The key factor in this method is actually the preparation of ketenes. The $N$-vinyl ketenimine $\mathbf{6 9}$ was prepared from the $N, P$-ylide $\mathbf{6 8}$ using this approach (eq 2). ${ }^{32}$

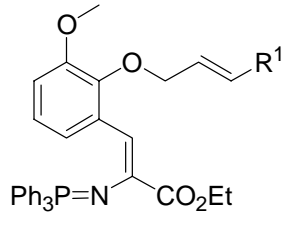

68

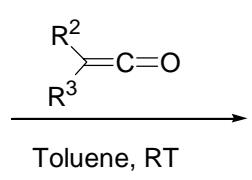

$\mathrm{R}^{1}=\mathrm{H}, \mathrm{Me}, \mathrm{Ph} ; \mathrm{R}^{2}=\mathrm{Ph}, p-\mathrm{Tol} ; \mathrm{R}^{3}=\mathrm{Et}, \mathrm{Ph}, p$-Tol



69

It is interesting to note that $N$-pyridyl iminophosphorane $\mathbf{7 0}$ reacts with both diphenylketene (71) and $N$-phenyl-diphenylketenimine (72) to give the $N$-(2-pyridyl)ketenimine 73 (Scheme 19). ${ }^{33}$ Under the reaction conditions, the ketenimine $\mathbf{7 3}$ spontaneously dimerized to 
afford the heterocyclic products $\mathbf{7 4}$ and $\mathbf{7 5}$. The relative yields of $\mathbf{7 4}$ and $\mathbf{7 5}$ depend on the molar ratio of the $N-P$ ylide $\mathbf{7 0}$ and the ketene $\mathbf{7 1}$ or the ketenimine $\mathbf{7 2}$ in the reaction $(1: 1$ of $\mathbf{7 0}$ to $\mathbf{7 1}$ gave $\mathbf{7 5}$ in $60 \%$ yield; $1: 3$ of $\mathbf{7 0}$ to $\mathbf{7 2}$ afforded $\mathbf{7 5}$ in 38\% yield; 1:3 of $\mathbf{7 0}$ to $\mathbf{7 1}$ afforded $\mathbf{7 4}$ in $88 \%$ yield).
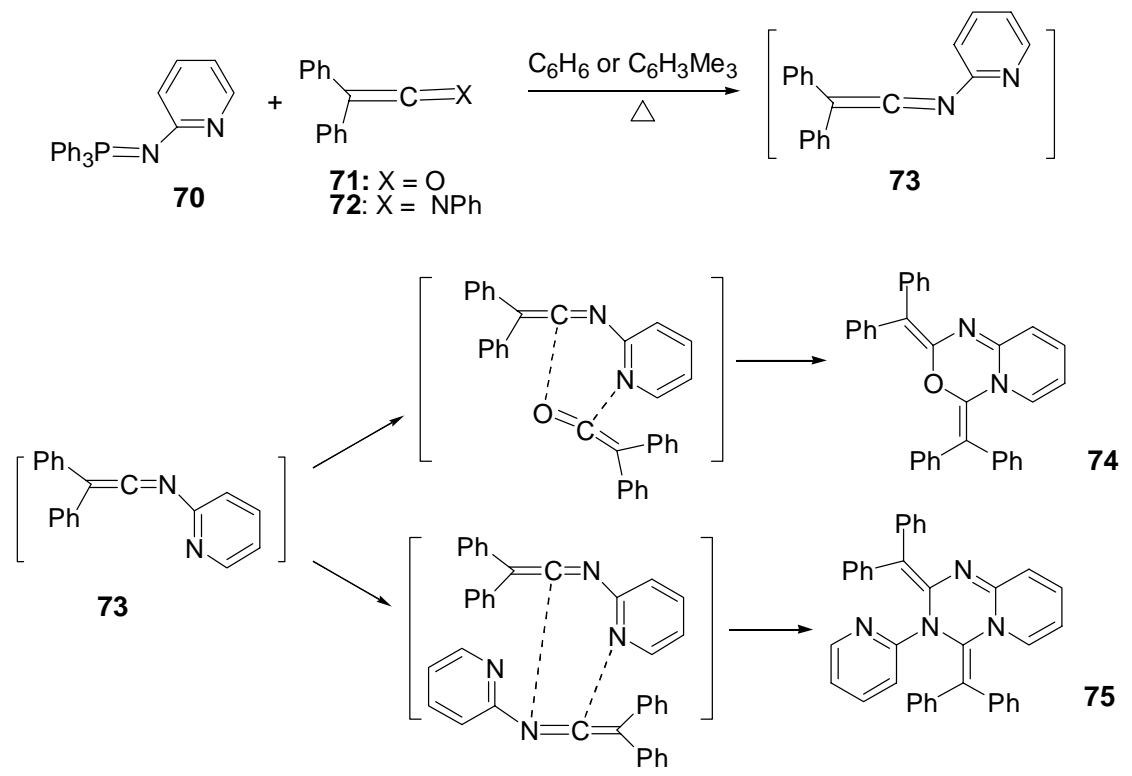

Scheme 19 Reactions of $N$-(2-Pyridyl)Ketenimine 73.

\subsubsection{From Phosphorus Ylides and Isocyanates or Related Compounds}

Historically, the first ketenimine, $\mathrm{Ph}_{2} \mathrm{C}=\mathrm{C}=\mathrm{NPh}$, was synthesized by Staudinger and Meyer from the reaction between phenyl isocyanate and diphenylmethylenetriphenylphosphorane. However, there is a potential problem about this methodology when the nonstablized ylides were used. For instance, the reaction between the isocyanate with $\mathrm{Me}_{2} \mathrm{C}=\mathrm{PPh}_{3}$ stopped at the bataine stage (76) (Scheme 20). Furthermore, bataines from nonstablized ylides bearing hydrogen(s) on the methylene carbon then rearranged to yield new ylides 77. Generally speaking, this method is not suitable for the reactions involving 
nonstablized ylides due to difficulty in inducing an elimination of triphenylphosphine oxide from the betaine intermediates.

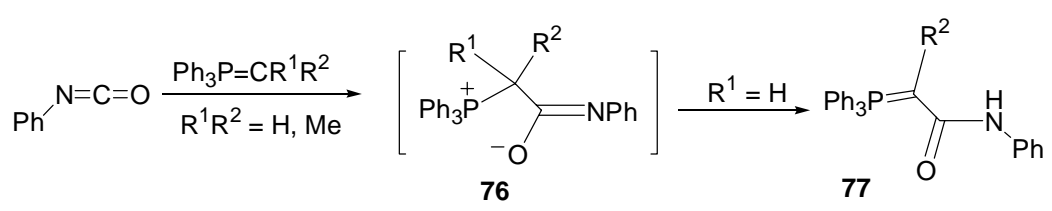

Scheme 20. The Rearrangement of the Bataine Intermediates.

Phenylmethoxycarbonylketene- $N$ - $t$-butylimine (79) was prepared in $92 \%$ yield by the reaction of methyl triphenylphosphoranylidenephenylacetate (78) with $t$-butyl isocyanate at 103 ${ }^{\circ} \mathrm{C}$ for 24 hours (eq 3$) .{ }^{34}$

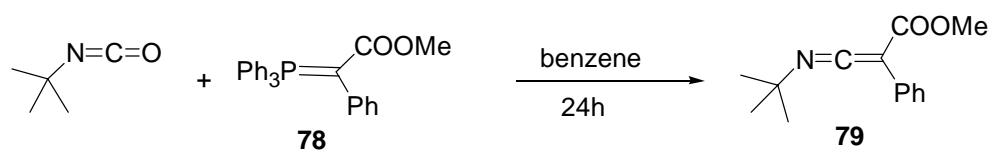

\subsection{Methods for the Synthesis of Carbodiimides}

For the preparation of carbodiimides, the usual starting materials are ureas, thioureas, isocyanates and isothiocyanates. The following are most widely cited methods.

\subsubsection{Dehydration of Ureas}

The widely used dehydrating agents include $\mathrm{Ph}_{3} \mathrm{PBr}_{2}, \mathrm{Ph}_{3} \mathrm{PCl}_{2}, \mathrm{PCl}_{5}$, $p$-toluenesulfonyl chloride, phosgene, and 2-chloro-1-methylpyridinium iodide (CMPI). The carbodiimides $\mathbf{8 1}$ were prepared from ureas $\mathbf{8 0}$ in good yields using this method (eq 4). ${ }^{35}$

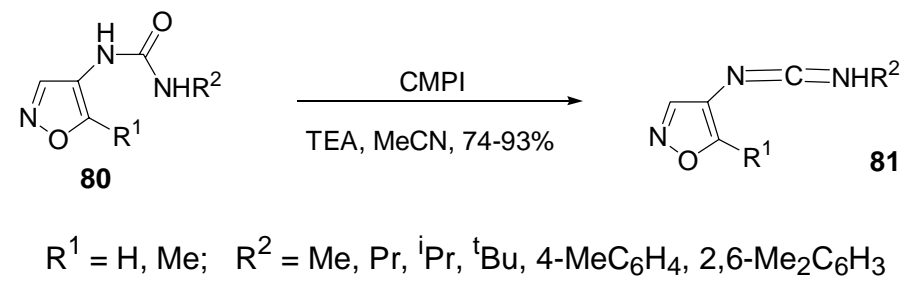




\subsubsection{Elimination of Hydrogen Sulfide from Thioureas}

The extrusion of hydrogen sulfide from $N, N$ '-disubstituted thioureas is one of the most commonly used methods for the preparation of carbodiimides. Pyridin-3-yl-[(1,2,2-trimethylpropylimino)methylene]amine (82) was prepared by the reaction of 1-pyridin-3-yl-3-(1,2,2trimethyl-propyl)thiourea (83) with $\mathrm{PPh}_{3} / \mathrm{CCl}_{4}$ in the presence of triethylamine (eq 5). ${ }^{36 \mathrm{a}}$ The carbodiimide $\mathbf{8 5}$ was also prepared from urea $\mathbf{8 4}$ in quantitative yield using this method (eq 6). ${ }^{36 \mathrm{~b}}$



82

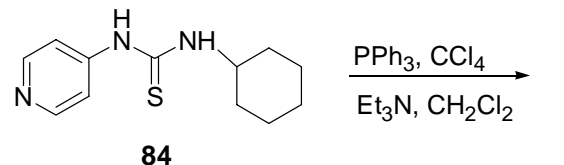

84
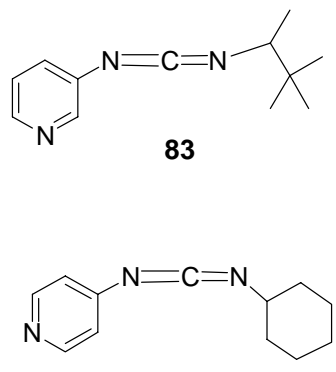

85

Recently, Isobe and Ishikawa synthesized phenyl-pyridin-3-yl-carbodiimide (87) by treatment of 1-phenyl-3-pyridin-3-yl-thiourea (86) with 2-chloro-1,3-dimethylimidazolinium chloride (DMC) in the presence of triethylamine (eq 7). ${ }^{37}$

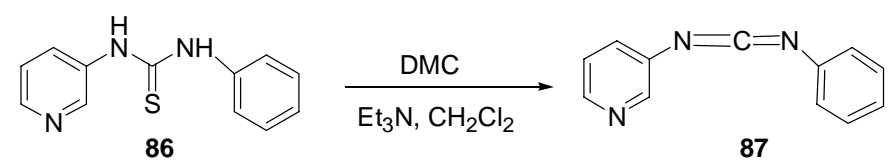

Fell and Coppola developed a mild, efficient, and rapid method for the conversion of mono- or diarylthioureas $\mathbf{8 8}$ to the corresponding carbodiimides $\mathbf{8 9}$ by treatment of the thiourea with methylsulfonyl chloride in the presence of triethylamine and a catalytic amount of 4dimethylaminopyridine (DMAP) (eq 8). ${ }^{38}$






\subsubsection{Aza-Wittig Reactions of Iminophosphoranes with Isocyanates or Isothiocyanates ${ }^{39}$}

This is another most common approach to the synthesis of carbodiimides. $\mathrm{N}$-Cyclohexyl$N^{\prime}$-(3-pyridyl)carbodiimide (91) was prepared by the reaction of 3-isocyanatopyridine with cyclohexyliminotriphenylphosphorane (90) in $83 \%$ yield (eq 9). ${ }^{40}$

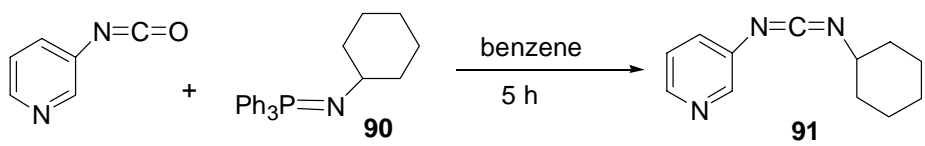

It is noteworthy that the pyridyl carbodiimides can be used as part of a diene or dienophile component in the Diels-Alder reaction. A very interesting example is the competition of the [4+2] cycloadditions of phenyl isocyanate (92) with $N$-Phenyl- $N$ '-(2-Pyridyl)carbodiimide

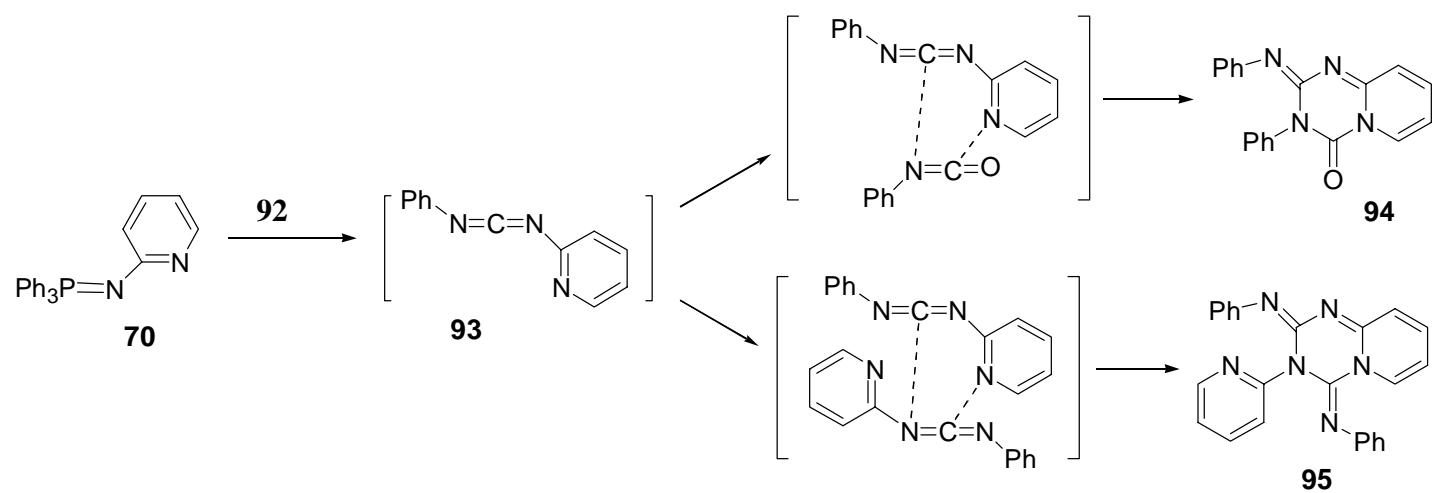

Scheme 21. Reactions of $N$-Phenyl-N'-(2-Pyridyl)carbodiimide 93.

(93) and 93 with itself, resulting in the formation of two heterocyclic products 94 and 95 as outlined in Scheme 21. The relative yields of 94 and 95 depend on the molar ratio of the $N-P$ ylide 70 and phenyl isocyanate $(\mathbf{9 2})$ in the reaction mixture $(1: 3.5$ ratio of $\mathbf{7 0}$ to 92 gave 94 in $83 \%$ yield; $1: 1.5$ ratio of 70 to 92 furnished 94 in 24\% yield and 95 in $50 \%$ yield). ${ }^{41}$

It is interesting to note that $N$-pyridyl iminophosphorane $\mathbf{7 0}$ (1 equiv) also reacts with diphenylcarbodiimide 96 ( 2 equiv), via the intermediate 97, to give the $N$-(2-pyridyl)ketenimine 
93 and $N$-P ylide 98 . The reactive 93 in turn undergoes a [4+2] cycloaddition with 96 to furnish 99 in $52 \%$ yield (Scheme 22). ${ }^{42}$

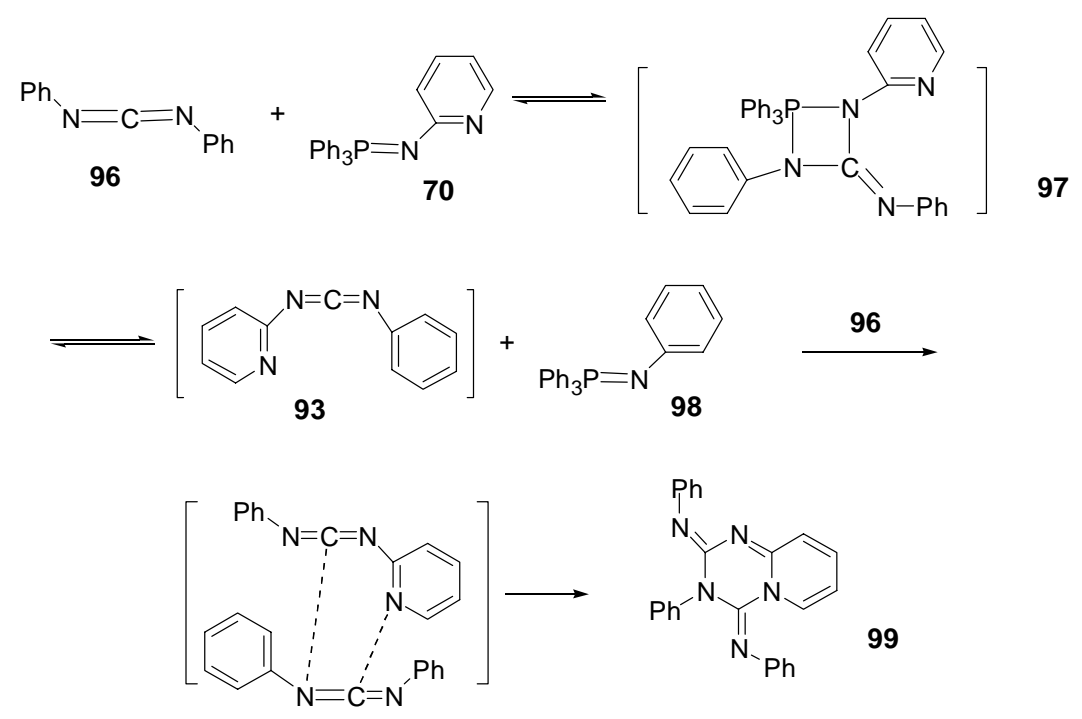

Scheme 22. Dimerization of the Mixed Carbodiimides. 


\section{Results and Discussion}

\subsection{Generation of Biradicals and Subsequent Formation of Quinolines and $\mathbf{5 H}$ -}

\section{Benzo $[b]$ carbazoles from $N$-[2-(1-Alkynyl)phenyl]ketenimines}

\subsubsection{Retrosynthetic Analysis}

It should be emphasized that ketenimines (1-alkenylideneamines) with a hydrogensubstituent or with a small-unbranched alkyl substituent are elusive substances. Ketenimines are reasonably stable when substituted with a stabilizing group such as an aryl, ${ }^{43}$ a phosphonium ylide group ${ }^{44}$ or a trimethylsilyl group. ${ }^{45,46}$ We reasoned that it would be a wise choice to start with relatively stable enyne-ketenimines in our model studies. Since incorporation of the central carbon-carbon double bond of acyclic enediynes into a benzene ring has little effect on the rate of the Bergman cyclization reaction, ${ }^{47}$ such system was chosen for the enyne-ketenimine system. This system is easy to construct and provides a variety of enyne-ketenimine systems for subsequent studies.

There are two kinds of enyne-ketenimines $\mathbf{1 0 0}$ and $\mathbf{1 0 1}$ for this system (Figure 2). We selected $\mathbf{1 0 0}$ in our study. For the preparation of ketenimines, the reasonably versatile and



Figure 2. Two Type of Enyne-Ketenimines.

general reactions are dehydration of secondary amides and elimination of hydrogen sulfide from thioamides and their derivatives. From the retrosynthetic viewpoint, ketenimines can also be disconnected in two ways: scission of the $\mathrm{N}=\mathrm{C}$ bond and excision of the $\mathrm{C}=\mathrm{C}$ bond in $\mathrm{N}=\mathrm{C}=\mathrm{C}$ systems. In other words, enyne-ketenimines $\mathbf{1 0 0}$ could also be synthesized by the aza-Wittig reaction of the corresponding iminophosphoranes with ketenes and by the reaction of phosphorus 
ylides with isocyanates or related compounds. The retrosynthetic analysis is summerized in Scheme 23. Among these, the aza-Wittig reaction is most appealing because of its mild reaction condition and easy accessibility, and therefore provides the great opportunity to isolate the key intermediates in the process.



Scheme 23. Retrosynthetic Analysis.

Diphenylketene was selected in this preliminary study because it would allow interamolecular coupling of the biradical intermediates. Moreover, diphenylketene is relatively stable and can be easily isolated and purified.

\subsubsection{Results and Discussions}

The Pd-catalyzed cross-coupling reactions between 2-iodoaniline and 1-alkynes furnished 102 in nearly quantitative yields. ${ }^{48}$ Treatment of $\mathbf{1 0 2}$ with $\mathrm{Ph}_{3} \mathrm{PBr}_{2}$ gave the iminophosphoranes 103 (Scheme 25). ${ }^{49 a}$ The aza-Wittig reaction between 103a $(\mathrm{R}=\mathrm{H}){ }^{49 \mathrm{~b}}$ and diphenylketene ${ }^{50}$ was carried out in benzene containing a large excess of 1,4-CHD at $0{ }^{\circ} \mathrm{C}$ followed by reflux for 2 hours to furnish the quinoline 106a $(\mathrm{R}=\mathrm{H})$ in $49 \%$ yield. Apparently, the reaction proceeded through an initial formation of the ketenimine 104a followed by cycloaromatization to produce the biradical 105a and subsequently 106a. Attempts to isolate 104a resulted in its decomposition after the solvent was removed. However, the IR spectrum taken immediately after 103a was 
treated with diphenylketene (strong absorptions at $2105 \mathrm{~cm}^{-1}$ in IR spectrum) ${ }^{50}$ in $\mathrm{C}_{6} \mathrm{D}_{6}$ containing an excess of 1,4-CHD exhibited an intense absorption at $2002 \mathrm{~cm}^{-1}$, attributable to
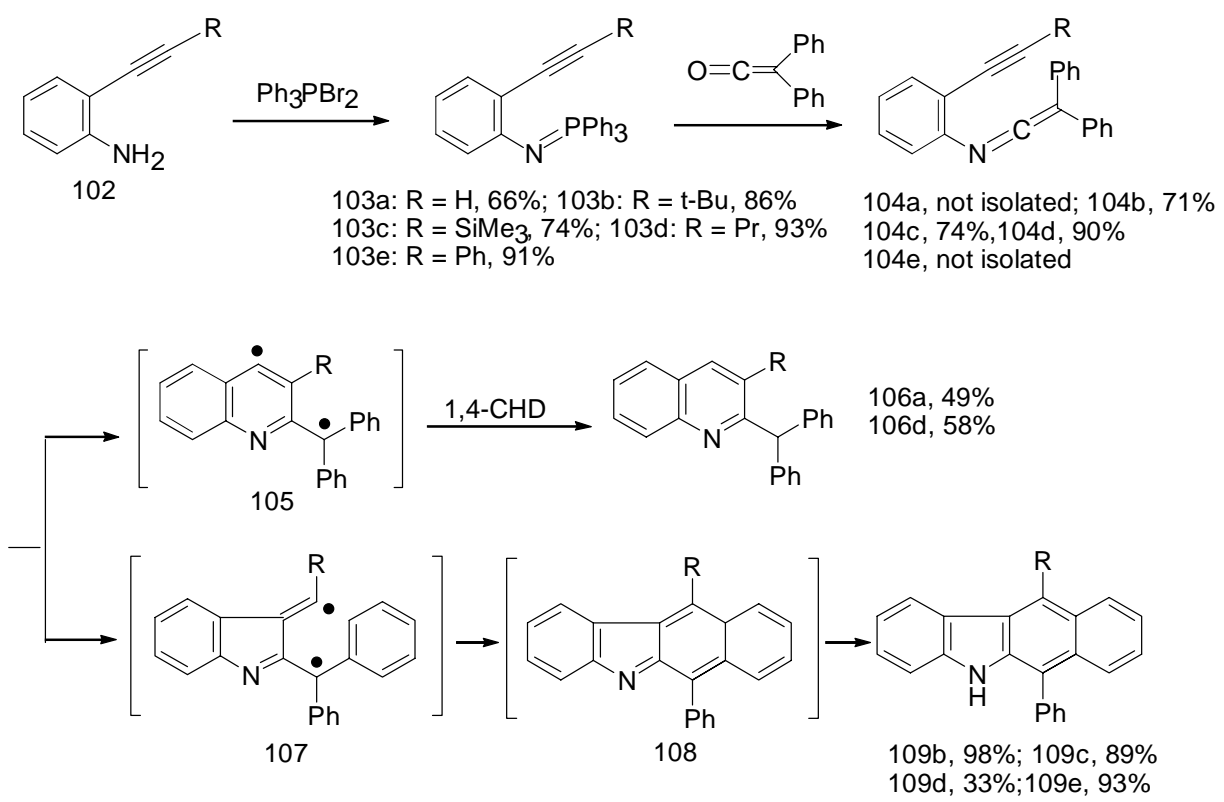

Scheme 24. Thermolysis of Enyne-Ketenimine 104.

104a. ${ }^{43}$ The ${ }^{1} \mathrm{H}$ NMR spectrum of the same solution also showed the disappearance of the acetylenic C-H signal of $\mathbf{1 0 3 a}^{49 b}$ at $\delta 3.26$ and the appearance of a new signal at $\delta 2.86$, attributable to the acetylenic $\mathrm{C}-\mathrm{H}$ of $\mathbf{1 0 4 a}$. The assignments of the signals were based on the systematic observation of the appearance and disappearance of the signals at $\delta 2.86$ and 3.86, and on the comparison of the signal at $\delta 2.51$ for $\mathbf{1 0 3 d}$ and the signal at $\delta 2.10$ for $\mathbf{1 0 4 d}$ of the proparagylic protons. The rate of disappearance of 104a and appearance of $\mathbf{1 0 6 a}$ was monitored with IR and ${ }^{1} \mathrm{H}$ NMR. The reaction exhibited clean first-order behavior over three half-lives with $k=1.87 \pm 0.04 \mathrm{~h}^{-1} \quad\left(t_{1 / 2}=0.37 \mathrm{~h}\right)$ at $22^{\circ} \mathrm{C}($ Figure 3$) .{ }^{51}$ 


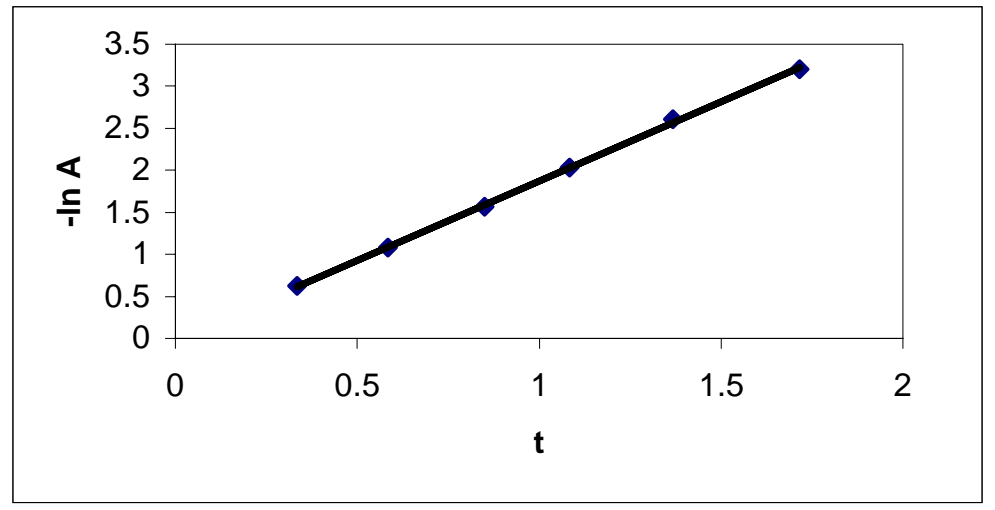

Figure 3. A Plot of -ln A versus Reaction Time $\mathrm{t}(\mathrm{hr})$ in the Case of 104a.

A: IR absorbance at $2002 \mathrm{~cm}^{-1}$

Treatment of $\mathbf{1 0 3 b}$ with diphenylketene furnished $\mathbf{1 0 4 b}$, which was isolated in $71 \%$ yield. Interestingly, thermolysis of $\mathbf{1 0 4 b}$ in refluxing benzene gave the benzocarbazole $\mathbf{1 0 9 b}$ in $98 \%$ yield. The cascade sequence outlined in Scheme 24 with an initial formation of a five-membered ring to produce biradical $\mathbf{1 0 7} \mathbf{b}$ followed by an intramolecular radical-radical combination to form $\mathbf{1 0 8 b}$ and a subsequent tautomerization could account for the formation of $\mathbf{1 0 9 b}$. The severe nonbonded steric interactions between the tert-butyl group at the C-3 position and the substituent at the C-2 position of the quinoline biradical $105 \mathrm{~b}(\mathrm{R}=$ tert-butyl) (figure 4$)$ is probably responsible for directing the reaction toward $\mathbf{1 0 7 b}$. Such a preference resembles the formation of the five-membered ring biradicals in several analogous cases of ring closures of enyne-ketenes ${ }^{19 a}$ and enyne-allenes. ${ }^{21.51}$

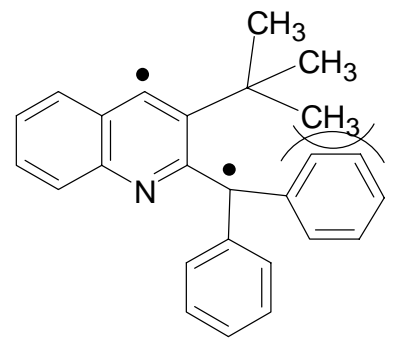

Figure 4. The Nonbonded Steric Interactions in $\mathbf{1 0 5 b}$. 
Alternatively, a one-step intramolecular Diels-Alder reaction of $\mathbf{1 0 4 b}$ could also produce $\mathbf{1 0 8 b}^{49 b, 25 a, 52}$ as reported previously by Differding and Ghosez in an elegant synthesis of carbazoles 64 by using 61 to generate in situ the acetylenic vinylketenimines 62 (Scheme 17). ${ }^{25 a}$ However, unlike 62, a sterically demanding tert-butyl group is at the acetylenic terminus of 104b. Examination of the molecular model for the transformation from $104 \mathrm{~b}$ to $108 \mathrm{~b}$ via the Diels-Alder mechanism reveals the severe nonbonded steric interactions in the transition state between the tert-butyl group and the phenyl group at the ketenimine terminus, making a concerted process highly unlikely (Figure 5). On the other hand, the two-step biradical



Figure 5. The Nonbonded Steric Interactions in the Diels-Alder Reaction.

mechanism permits the sterically demanding tert-butyl group to bend away in the first step, greatly reducing the steric interactions and allowing the reaction to occur under relatively mild thermal conditions $\left(k=0.186 \pm 0.004 \mathrm{~h}^{-1}, t_{1 / 2}=3.73 \mathrm{~h}\right.$ at $72{ }^{\circ} \mathrm{C}$.) (Figure 6). With the absence of an apparent proton source, it is also unlikely that the reaction could proceed through a cationic reaction mechanism involving an initial protonation of the nitrogen atom in $\mathbf{1 0 4 b}$. 


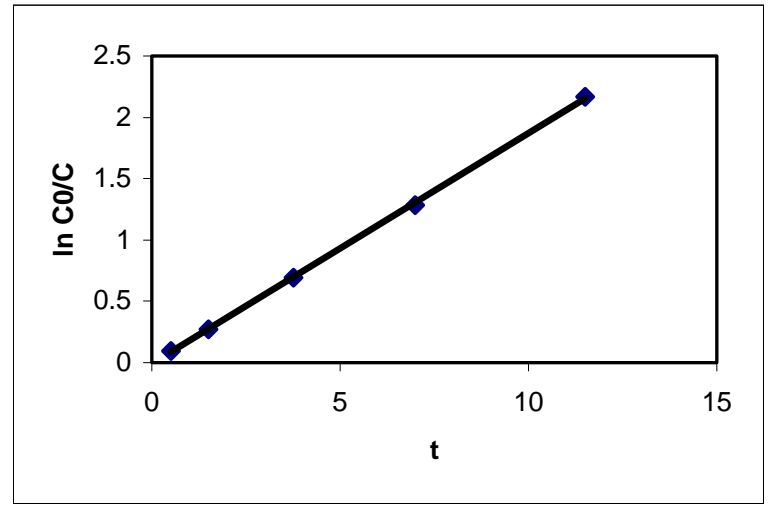

Figure 6. A Plot of $\ln \mathrm{C}_{0} / \mathrm{C}$ versus Reaction Time t (hr) in the Case of 104b.

$\mathrm{C}_{0}$ and $\mathrm{C}$ are the concentrations of reactant $\mathbf{1 0 4 b}$ at $\mathrm{t}=0$ and $\mathrm{t}=\mathrm{t}$, respectively.

When $104 \mathrm{c}\left(\mathrm{R}=\mathrm{SiMe}_{3}\right)$ was heated under refluxing benzene, the benzocarbazole 109c was produced $\left(k=0.78 \pm 0.06 \mathrm{~h}^{-1}, t_{1 / 2}=0.89 \mathrm{~h}\right.$ at $\left.72{ }^{\circ} \mathrm{C}\right)$ (Figure 7$){ }^{55}$ The ability of the trimethylsilyl group in stabilizing the adjacent radical site in $\mathbf{1 0 7} \mathbf{c}^{56}$ along with the arising of nonbonded interactions in $\mathbf{1 0 5 c}$ direct the reaction toward $\mathbf{1 0 9}$.

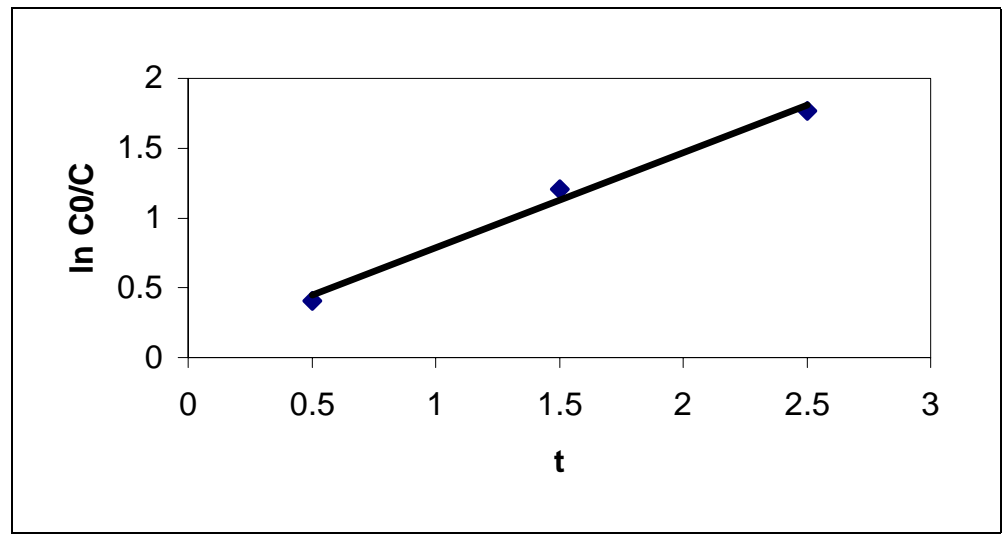

Figure 7. A Plot of $\ln \mathrm{C}_{0} / \mathrm{C}$ versus Reaction Time $\mathrm{t}(\mathrm{hr})$ in the Case of $\mathbf{1 0 4 c}$.

$\mathrm{C}_{0}$ and $\mathrm{C}$ are the concentrations of reactant $104 \mathrm{c}$ at $\mathrm{t}=0$ and $\mathrm{t}=\mathrm{t}$, respectively. 
Thermolysis of $\mathbf{1 0 4 d}(\mathrm{R}=\mathrm{Pr})$ in refluxing 1,4-CHD furnished the quinoline $\mathbf{1 0 6} \mathbf{d}(58 \%)$ and the benzocarbazole 109d (33\%) ( $k$ of the disappearance of $\mathbf{1 0 4 d}=1.01 \pm 0.11 \mathrm{~h}^{-1}, t_{1 / 2}=0.69$ h at $52^{\circ} \mathrm{C}$ ) (Figure 8). ${ }^{57}$ Apparently, the reaction could proceed through biradicals $\mathbf{1 0 5 d}$ and



Figure 8. A Plot of $\ln \mathrm{C}_{0} / \mathrm{C}$ versus Reaction Time $\mathrm{t}(\mathrm{hr})$ in the Case of 104d. $\mathrm{C}_{0}$ and $\mathrm{C}$ are the concentrations of reactant $\mathbf{1 0 4} \mathbf{d}$ at $\mathrm{t}=0$ and $\mathrm{t}=\mathrm{t}$, respectively.

107d with comparable efficiency. If one compares the rate of formation of $\mathbf{1 0 9 d}\left(k=0.36 \mathrm{~h}^{-1}\right.$, $t_{1 / 2}=1.93 \mathrm{~h}$ at $52{ }^{\circ} \mathrm{C}$ ) with that of $\mathbf{1 0 9 b}$, the steric factors do not appear to affect the rate of reaction dramatically, again contrary to what would be expected of a concerted Diels-Alder mechanism. When 103e $(\mathrm{R}=\mathrm{Ph})$ was treated with diphenylketene at room temperature for one hour, the benzocarbazole 109e (93\%) was produced exclusively. Presumably, because the phenyl substituent can further stabilize the vinyl radical site ${ }^{58}$ in $\mathbf{1 0 7 e}$, the ketenimine 104e was thermally labile and was readily converted to $\mathbf{1 0 9 e}$.

A similar study was also reported by Schmittel, Engels, and co-workers recently. ${ }^{25 f}$ To demonstrate experimentally that biradical $\mathbf{1 0 7 f}$ is an intermediate, they replaced two phenyl groups at the ketenimine terminus with two bulky mesityl substituents in 104f. The product was 111 with the loss one of the methyl groups at the ortho position (Scheme 25). The stepwise 
biradical route is most likely the reaction pathway because the concerted Diels-Alder reaction suffers from severe steric hindrance.

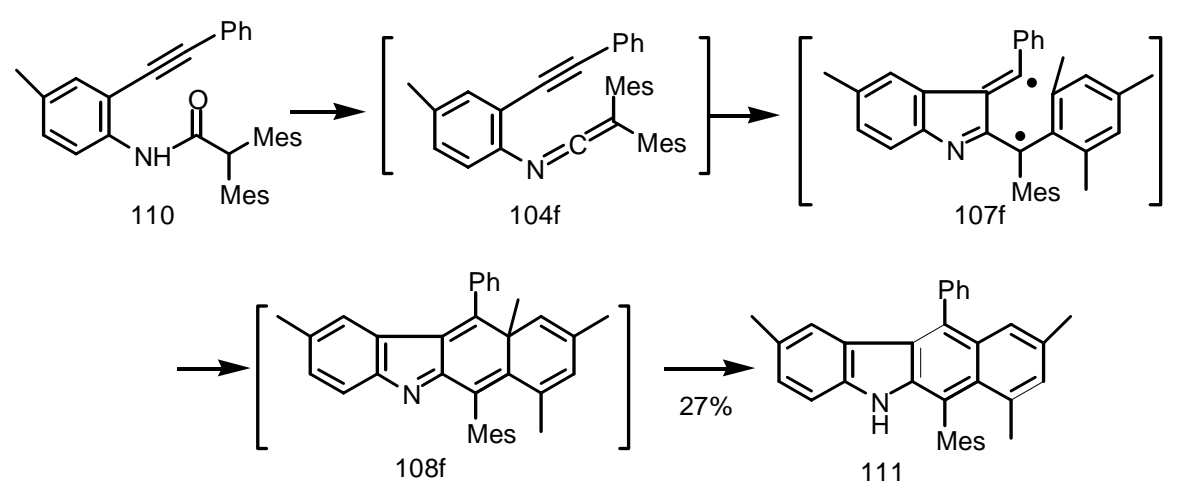

Scheme 25. Schmittel's Observation.

Alternatively, the ketenimines $\mathbf{1 0 4}$ could also be produced in situ by dehydration of $\mathbf{1 1 2}$ with $\mathrm{P}_{2} \mathrm{O}_{5}$ in refluxing pyridine, ${ }^{27}$ leading to $106 \mathbf{a}(34 \%), \mathbf{1 0 6 d}(35 \%), \mathbf{1 0 9 d}(31 \%)$, and 109e (70\%) (Scheme 26). In the case of $\mathbf{1 1 2} \mathbf{c}\left(\mathrm{R}=\mathrm{SiMe}_{3}\right)$, the resulting benzocarbazole 109c is prone

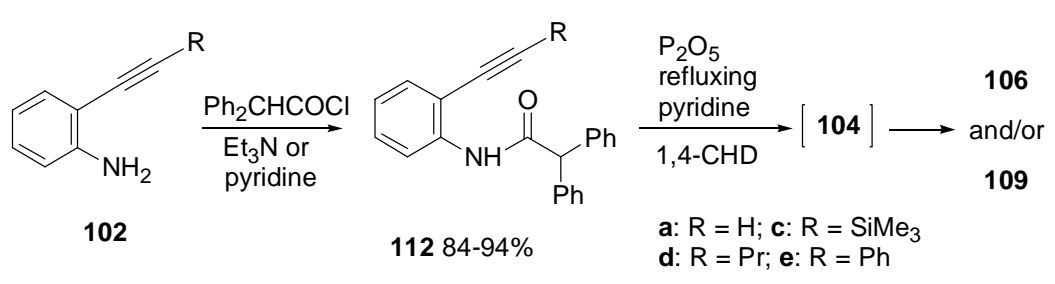

Scheme 26. One Pot Reactions Involving Ketenimine Intermediates.

to protodesilylation under the reaction condition, and a significant amount of the desilylated adduct 109a $(\mathrm{R}=\mathrm{H})$ was produced. Treatment of the reaction mixture with $1 \mathrm{~N} \mathrm{HCl}$ at $40{ }^{\circ} \mathrm{C}$ for one hour completely converted $109 \mathrm{c}$ to $109 \mathrm{a}$, which was isolated in an overall yield of $81 \%$ from 112c. It is interesting to note that benzo[b]carbazole 109a could not be prepared directly from the corresponding amide 112a or the iminophosphorane 103a, which leads to the quinoline 106a because the corresponding key intermediate 104a only undergoes Myers' cycloaromatization.

By starting from 113, derived from acylation of 102e with phenylacetyl chloride $(97 \%$ 
yield), the benzocarbazole 114 was produced in $27 \%$ isolated yield (eq 10).



The synthetic methods for benzo[b]carbazoles outlined in Scheme 24 and 26 represent new and efficient routes to these heterocyclic compounds. Compared with the other reported methods, the ready availability of the starting materials and the short pathways are especially attractive features. For example, a multi-step synthetic route to benzo[b]carbazoles involving an intermolecular Diels-Alder reaction of 2,4-dihydropyrrolo[3,4-b]indole derivatives ${ }^{59}$ (122) with highly reactive dienophiles, such as benzyne, was reported by Sha and co-workers (Scheme 27). ${ }^{59 \mathrm{~d}}$

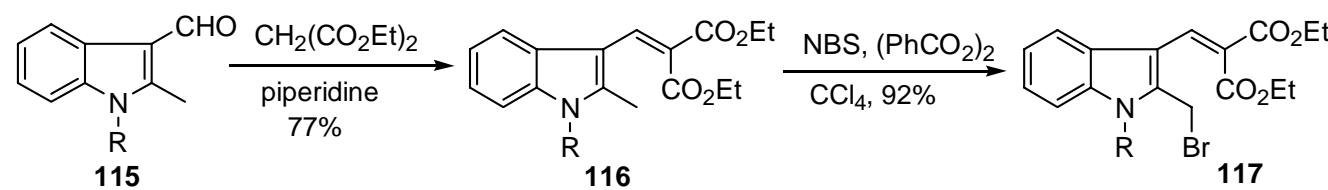

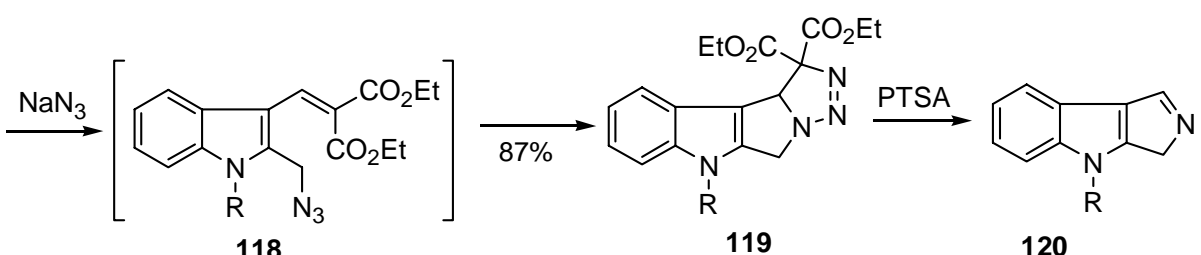

118 119

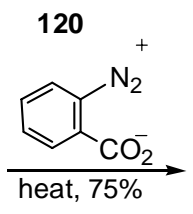

121<smiles>CC(=O)n1cc2c3ccccc3n(P)c2c1</smiles>
122

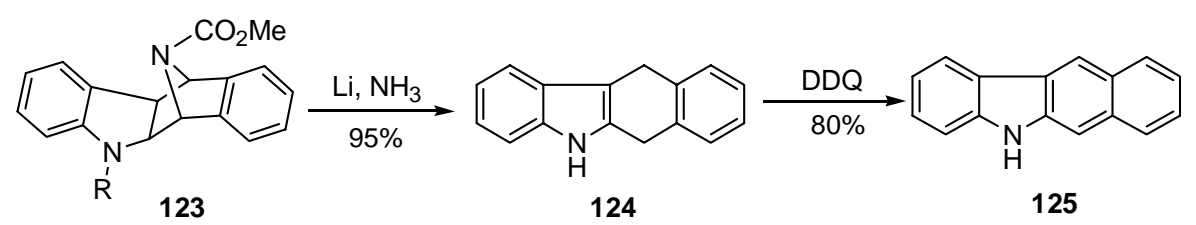<smiles>[PH][PH]</smiles>
PTSA $=p$-toluenesulfphonic acid

Scheme 27. Synthesis of $5 H$-Benzo $[b]$ carbazole. 
The structures of $\mathbf{1 0 3 a}^{49 b}, \mathbf{1 0 4 d}, \mathbf{1 0 6} \mathbf{d}, \mathbf{1 0 9} \mathbf{d}$, the other quinolines and benzo $[b]$ carbazoles were fully characterized by spectroscopic methods.

The ${ }^{1} \mathrm{H}$ NMR spectrum of 103a showed a characteristic acetylenic proton signal at $\delta 3.34$ $(1 \mathrm{H}, \mathrm{s})$ along with nineteen hydrogens in the aromatic region between $\delta 7.88$ and 6.47 . The ${ }^{13} \mathrm{C}$ NMR spectrum gave expected 12 signals as reported previously ${ }^{49 b}: \delta 153.57\left(\mathrm{C}_{1}\right), 133.57\left(\mathrm{C}_{3}\right)$, $132.61\left(\mathrm{~d},{ }^{2} J_{P-C}=9.8 \mathrm{~Hz}, \mathrm{C}_{10}\right), 131.63\left(\mathrm{~d},{ }^{4} J_{P-C}=2.6 \mathrm{~Hz}, \mathrm{C}_{12}\right), 130.92\left(\mathrm{~d},{ }^{1} J_{P-C}=99.7 \mathrm{~Hz}, \mathrm{C}_{9}\right)$, $128.82\left(\mathrm{C}_{4}\right), 128.49\left(\mathrm{~d},{ }^{3} J_{P-C}=11.9 \mathrm{~Hz}, \mathrm{C}_{11}\right), 121.19\left(\mathrm{~d},{ }^{3} J_{P-C}=9.8 \mathrm{~Hz}, \mathrm{C}_{6}\right), 117.23\left(\mathrm{~d},{ }^{3} J_{P-C}=\right.$ $\left.23.2 \mathrm{~Hz}, \mathrm{C}_{2}\right), 116.80\left(\mathrm{C}_{5}\right), 85.12\left(\mathrm{C}_{7}\right), 79.22\left(\mathrm{C}_{8}\right)$.



Figure 9. Numbering of 103a.

The ketenimine intermediates exhibit characteristic IR absorption at $2000-2050 \mathrm{~cm}^{-1}$ $(\mathrm{N}=\mathrm{C}=\mathrm{C})$ and ${ }^{13} \mathrm{C}$ NMR signal at $\delta 190-200$ ppm for the central carbon of the ketenimine moiety $\left(\mathrm{N}=\mathrm{C}^{*}=\mathrm{C}\right)$. For $\mathbf{1 0 4 d}$, a strong absorption at $2004 \mathrm{~cm}^{-1}(\mathrm{~N}=\mathrm{C}=\mathrm{C})$ in the IR spectrum and signals at $\delta 189.41\left(\mathrm{~N}=\mathrm{C}^{*}=\mathrm{C}\right), 97.30(\mathrm{C} \equiv \mathrm{C})$ and $76.78(\mathrm{C} \equiv \mathrm{C}) \mathrm{ppm}$ in the ${ }^{13} \mathrm{C}$ NMR spectrum. The ${ }^{1} \mathrm{H}$ NMR spectrum of 104d showed the characteristic propyl signals at $\delta 2.10(2 \mathrm{H}, \mathrm{t}, J=7.2 \mathrm{~Hz})$, $1.47(2 \mathrm{H}$, sextet, $J=7.3 \mathrm{~Hz})$ and $0.94(3 \mathrm{H}, \mathrm{t}, J=7.4 \mathrm{~Hz})$ and exhibited signals for fourteen aromatic hydrogens in the aromatic region between $\delta 7.49$ and 7.16 .

Thermolysis of $104 \mathbf{d}$ gave two isolated products $106 \mathrm{~d}$ and $109 \mathrm{~d}$. For $106 \mathrm{~d}$, the mass spectrum showed the molecular ion with two mass units higher than that of the starting material 104d, in agreement the proposed hydrogen-atom abstraction mechanism. The ${ }^{1} \mathrm{H}$ NMR spectrum showed fifteen hydrogens in the aromatic region $(\delta 7.49-7.16)$. In addition, the ${ }^{1} \mathrm{H}_{-}{ }^{13} \mathrm{C}$ COSY 
and ${ }^{13} \mathrm{C}$ APT NMR spectra showed eight C-H and five quaternary carbon signals in the aromatic region. The ${ }^{1} \mathrm{H}$ NMR signal at $\delta 7.91\left(1 \mathrm{H}, \mathrm{s}, \mathrm{C}_{4}-\mathrm{H}\right)$ and a new alkyl C-H signal at $\delta 6.03(1 \mathrm{H}, \mathrm{s}$, $\left.\mathrm{C}_{11}-\mathrm{H}\right)$ as well as a ${ }^{13} \mathrm{C}$ NMR signal at $\delta 54.85\left(\mathrm{C}_{11}\right)$ are consistent with the structure of $\mathbf{1 0 6 d}$. The tentative assignments of chemical shifts are listed in Table 1.

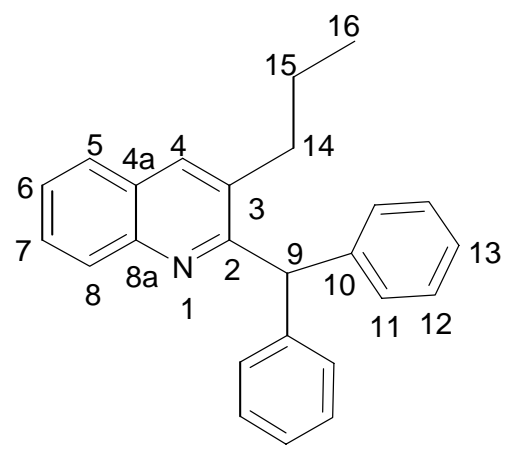

Figure 10. Numbering of 106d.

\begin{tabular}{|c|c|c|c|c|c|c|c|c|c|}
\hline No. & 2 & 3 & 4 & $4 a$ & 5 & 6 & 7 & 8 & $8 \mathrm{a}$ \\
\hline $\mathrm{CHn}$ & $\mathrm{C}$ & $\mathrm{C}$ & $\mathrm{CH}$ & $\mathrm{C}$ & $\mathrm{CH}$ & $\mathrm{CH}$ & $\mathrm{CH}$ & $\mathrm{CH}$ & $\mathrm{C}$ \\
\hline $\mathrm{H}$ & & & 7.91 & & 8.03 & 7.62 & 7.48 & 7.76 & \\
\hline $\mathrm{C}$ & 161.46 & 134.28 & 135.38 & 127.08 & 129.48 & 128.07 & 126.66 & 125.95 & 146.41 \\
\hline \hline $\mathrm{No}$ & 9 & 10 & 11 & 12 & 13 & 14 & 15 & 16 & \\
\hline $\mathrm{CHn}$ & $\mathrm{CH}$ & $\mathrm{C}$ & $\mathrm{CH}$ & $\mathrm{CH}$ & $\mathrm{CH}$ & $\mathrm{CH} 2$ & $\mathrm{CH} 2$ & $\mathrm{CH} 3$ & \\
\hline $\mathrm{H}$ & 6.03 & & $7.4-7.2$ & $7.4-7.2$ & $7.4-7.2$ & 2.85 & 1.74 & 1.05 & \\
\hline $\mathrm{C}$ & 54.85 & 142.95 & 128.07 & 129.68 & 126.25 & 34.63 & 23.78 & 14.13 & \\
\hline
\end{tabular}

Table 1. Tentative Chemical-Shift Assignments of NMR Spectra of 106d.

The molecular ion of the benzo[b]carbazole 109d has the same mass as the starting material 104d $\left(\mathrm{m} / \mathrm{z} 335, \mathrm{M}^{+}\right)$. Except the three propyl carbons, all other carbon signals are located in the aromatic region. In the ${ }^{1} \mathrm{H}$ NMR spectrum, 109d has one less aromatic proton, but one extra N-H signal at $\delta 7.82(1 \mathrm{H}$, br s) compared with the starting material 104d. The benzylic methylene group exhibited a triplet $(\delta 3.75)$ which was shifted downfield. The IR 
spectrum also showed the N-H absorption at $3402 \mathrm{~cm}^{-1}$. The tentative assignments of NMR signals are listed in Table 2 based on the ${ }^{1} \mathrm{H}-{ }^{13} \mathrm{C}$ COSY and ${ }^{13} \mathrm{C}$ APT NMR spectra.

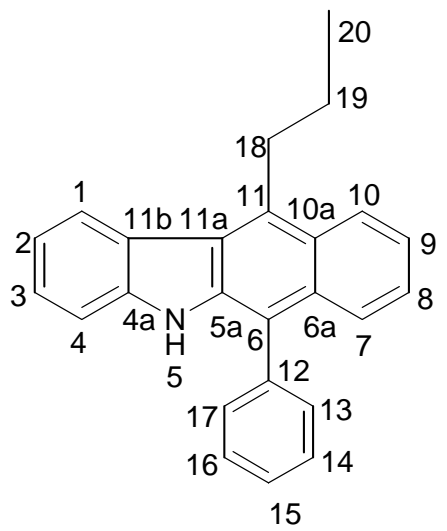

Figure 11. Numbering of 109d.

\begin{tabular}{|c|c|c|c|c|c|c|c|c|c|}
\hline No. & $\overline{1}$ & 2 & 3 & $\overline{4}$ & $4 a$ & 5 & $5 a$ & 6 & $6 \mathrm{a}$ \\
\hline $\mathrm{CHn}$ & $\mathrm{CH}$ & $\mathrm{CH}$ & $\mathrm{CH}$ & $\mathrm{CH}$ & C & $\mathrm{NH}$ & C & C & C \\
\hline$\overline{\mathrm{H}}$ & 7.83 & $7.7-7.2$ & $7.7-7.2$ & $7.7-7.2$ & & 7.82 & & & \\
\hline $\mathrm{C}$ & 125 & 119.44 & 122.39 & 110.05 & 137.39 & & 137.05 & 12261 & 126.88 \\
\hline 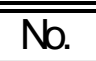 & $\overline{\overline{7}}$ & $\overline{\overline{8}}$ & $\overline{\overline{9}}$ & $\overline{\overline{10}}$ & $10 \mathrm{a}$ & $\overline{\overline{111}}$ & $\overline{\overline{11 a}}$ & 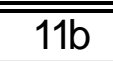 & 12 \\
\hline $\mathrm{aHn}$ & $\overline{\mathrm{CH}}$ & $\overline{\mathrm{CH}}$ & $\overline{\mathrm{CH}}$ & $\overline{\mathrm{CH}}$ & $\bar{C}$ & $\bar{C}$ & $\bar{C}$ & $\bar{C}$ & C \\
\hline $\bar{H}$ & 8.38 & $7.7-7.2$ & 7.7-7.2 & 8.28 & & & & & \\
\hline C & 124.15 & 126.67 & 124.81 & 123.61 & 141.99 & 133.87 & 122.61 & 130.83 & 123.61 \\
\hline$\overline{\mathrm{Nob}}$. & $\overline{\overline{13}}$ & $\overline{\overline{14}}$ & $\overline{\overline{15}}$ & $\overline{\overline{16}}$ & $\overline{\overline{17}}$ & $\overline{\overline{18}}$ & $\overline{\overline{19}}$ & 20 & \\
\hline $\mathrm{CHn}$ & $\overline{\mathrm{CH}}$ & $\overline{\mathrm{CH}}$ & $\overline{\mathrm{CH}}$ & $\mathrm{CH}$ & $\overline{\mathrm{CH}}$ & $\mathrm{CH}-2$ & $\mathrm{CH}-2$ & $\mathrm{CHB}$ & \\
\hline $\mathrm{H}$ & $7.7-7.2$ & $7.7-7.2$ & $7.7-7.2$ & 7.7-7.2 & $7.7-7.2$ & 3.75 & 202 & 1.3 & \\
\hline C & 129.22 & 130.99 & $\begin{array}{l}127.7 \\
\end{array}$ & 130.99 & 129.22 & 31.37 & 23.18 & 14.8 & \\
\hline
\end{tabular}

Table 2. Tentative Chemical-Shift Assignments of NMR Signals of 109d.

\subsubsection{Summary}

Similar to the enyne-allene system, the enyne-ketenimines 104 having a nitrogen atom in the conjugated system could serve as excellent precursors for generation of biradicals. Because of prevalence of the amide functionality in biological systems, structures similar to those of $\mathbf{1 1 2}$ are particularly attractive for the development of new DNA-cleaving agents. The cascade 
sequences outlined in Schemes 24 and 26 also provide efficient and flexible alternative pathways to quinolines and $5 H$-benzo $[b]$ carbazoles. $^{49 b, 59}$

\subsection{Biradicals from Thermolysis of $N$-[2-(1-Alkynyl)phenyl]- $N$ '-phenylcarbodiimides and Their Subsequent Transformations to 6H-Indolo[2,3-b]quinolines}

\subsection{General Strategy}

The successful study of using the enyne-ketenimine system for biradical formation and Schmittel, Engels and co-workers' similar results demonstrate the feasibility of placing a nitrogen atom in the conjugated system for the generation of biradicals under mild thermal conditions, providing a new avenue for the design of novel DNA-cleaving agents. ${ }^{1 \mathrm{c}, 1 \mathrm{~d}}$ A logical extension of this work involves replacing the ketenimine moiety in the conjugated system with other heterocumulenes. Carbodiimide appears to be an excellent candidate for such a substitution. A success of using such a system would add a new example of a growing list of the thermally-induced biradical-forming cycloaromatization reactions and provide a new approach to the synthesis of indolo[2,3-b]quinolines and 2-aminoquinolines. There has been a surge of interest in developing new synthetic pathways to $6 H$-indolo[2,3-b] quinolines ${ }^{49,60}$ recently because several members of this group of compounds have been found to possess interesting biological activities. $^{61}$

As mentioned earlier, many practical synthetic routes for the synthesis of carbodiimides are well documented in the literature. Among the widely cited methods, the aza-Wittig reaction between the iminophosphoranes and isocyanates is one of the most effective approaches.

Condensation between the iminophosphoranes $\mathbf{1 0 3}$ and isocyanates could thus lead to the enynecarbodiimide systems. 


\subsubsection{Results and Discussion}

The aza-Wittig reaction between $\mathbf{1 0 3}$ and phenyl isocyanate in anhydrous benzene furnished enyne-carbodiimide $\mathbf{1 2 6}$ in good yields. Thermolysis of isolated $\mathbf{1 2 6}$ gave the 2aminoquinoline $\mathbf{1 2 8}$ and the $6 H$-indolo[2,3-b]quinolines $\mathbf{1 3 1}$.

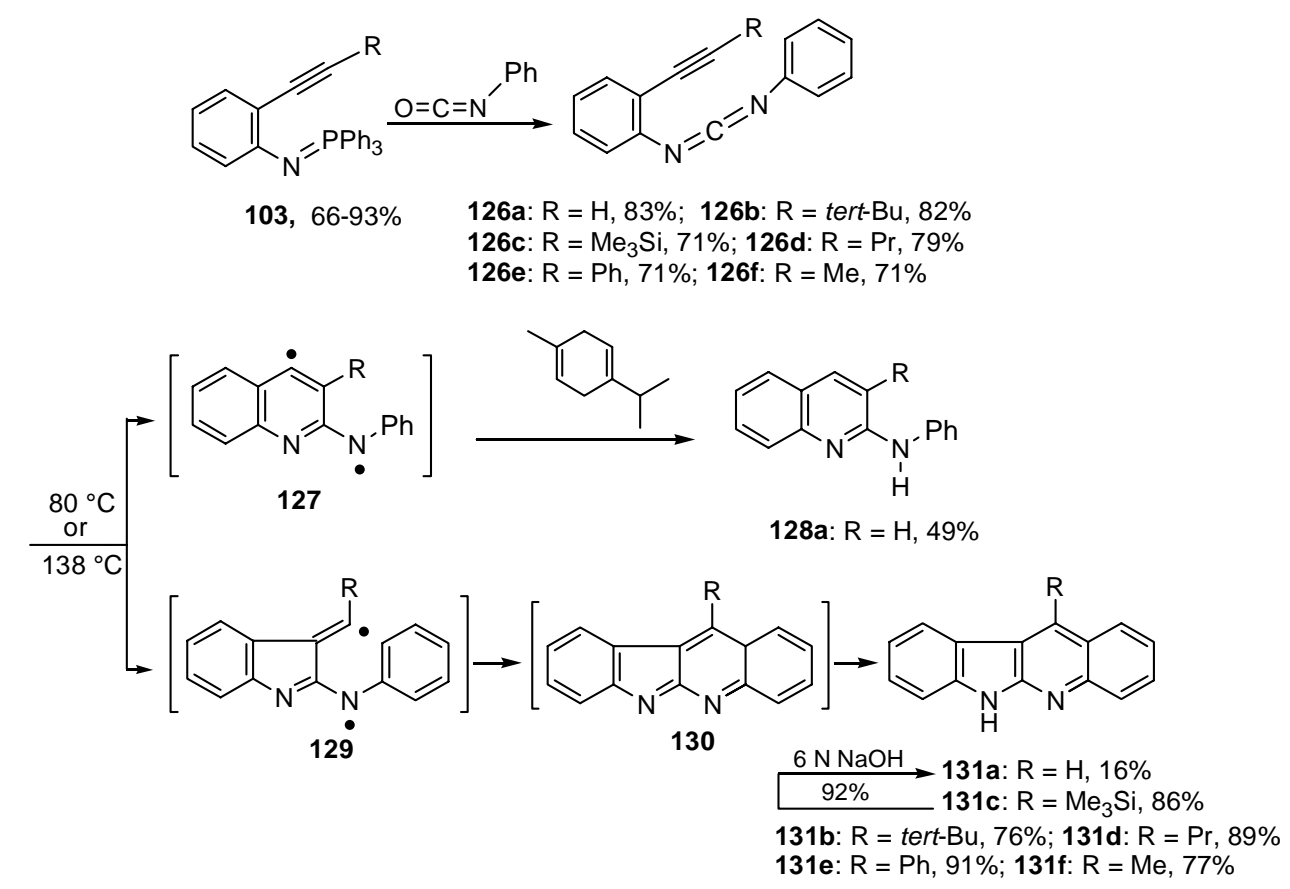

Scheme 28. Thermolysis of Enyne-Carbodiimide 126.

It was interesting to learn that carbodiimide 126a had already been prepared previously by treatment of iminophosphorane 103a $(\mathrm{R}=\mathrm{H})$ with phenyl isocyanate. ${ }^{25 b}$ Thermolysis of 126a in toluene at $160{ }^{\circ} \mathrm{C}$ in a sealed tube furnished 2-(phenylamino)quinoline (128a, 40\%) and the parent $6 H$-indolo[2,3-b]quinoline (131a, 19\%). ${ }^{25 b}$ We were able to reproduce similar results by heating 126a, isolated in $83 \%$ yield from treatment of 103a with phenyl isocyanate, in $\gamma$ terpinene at $138{ }^{\circ} \mathrm{C}$ to afford 128a (49\%) and 131a (16\%). Apparently, 128a was produced via the biradical 127a followed by hydrogen-atom abstraction from $\gamma$-terpinene. A two-step biradical pathway through 129a or a one-step intramolecular Diels-Alder reaction could furnish 130a, which then underwent tautomerization to give 131a. Several analogous examples in which 
a carbon-carbon double bond replaces the triple bond in $\mathbf{1 2 6}$ for the intramolecular Diels-Alder reaction have been reported. ${ }^{49,60}$ The indoloquinoline 131a was used as an immediate precursor for the synthesis of a naturally occurring alkaloid, 5-methyl-5H-indolo[2,3- $b]$ quinoline (132a) (eq 11), ${ }^{25 b, 61}$ which was isolated from the roots of the West African plant Cryptolepis sanguinolenta $^{62}$ and was found to possess interesting biological activities. ${ }^{61}$
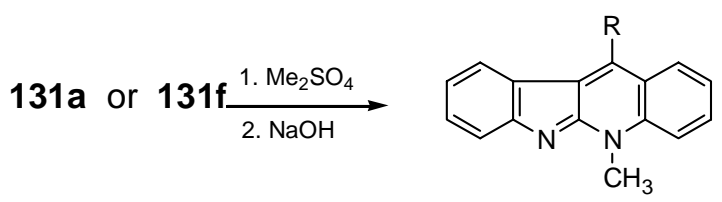

132a: $R=H, 42 \%$ 132f: $R=M e, 65 \%$

Molina and co-workers reported a useful and efficient synthesis of 131a (Scheme 29) ${ }^{63}$ as an alternative to the synthetic method outlined in Scheme 28. However, it is lengthy, involving multiple steps.
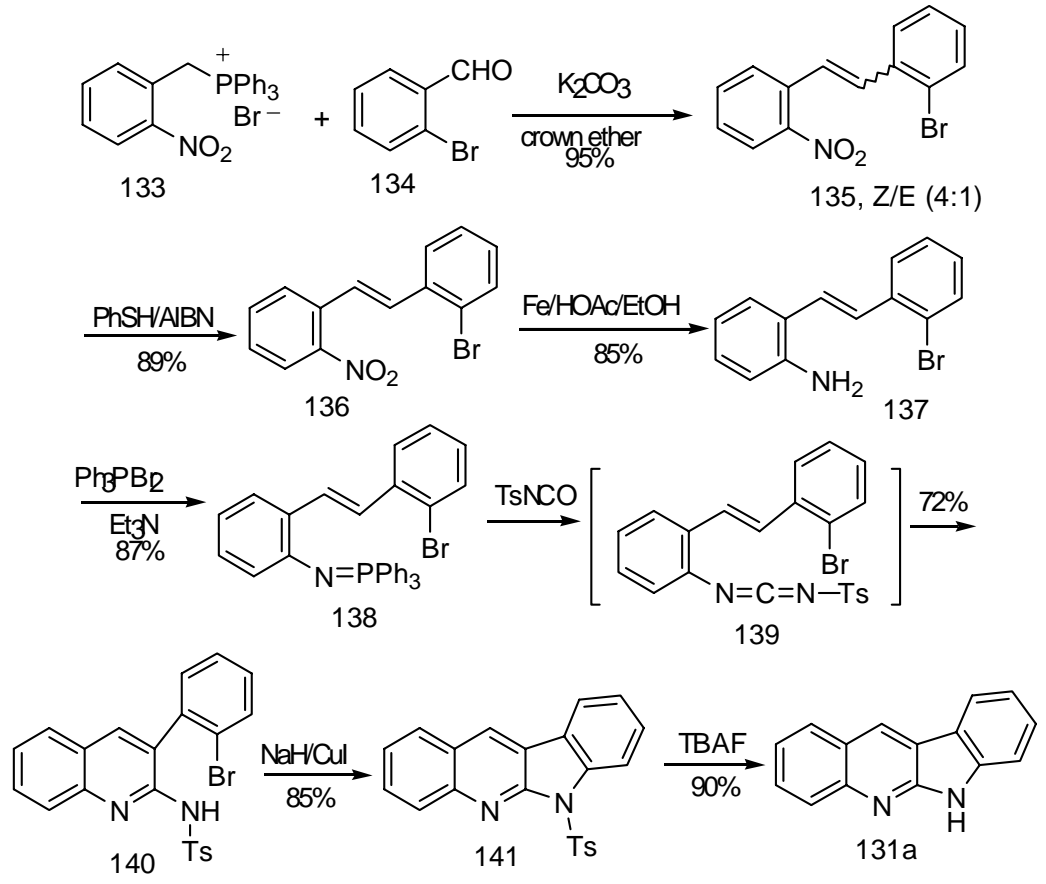

Scheme 29. Molina's Synthesis of 131a. 
The reaction sequence outlined in Scheme 28 could provide a more efficient route to the indoloquinoline 131a if the competing pathway toward the quinoline 128a could be suppressed. The result with 126c suggests that a trimethylsilyl group at the acetylenic terminus could serve as a surrogate for the hydrogen atom in directing the reaction toward the indoloquinoline 131c. A subsequent protodesilylation reaction could lead to 131a. It was gratifying to observe that thermolysis of 126c, obtained in 71\% from 103c and phenyl isocyanate, in refluxing $p$-xylene at $138^{\circ} \mathrm{C}$ produced $131 \mathrm{c}$ in $86 \%$ yield. Similarly, heating the reaction mixture of $103 \mathrm{c}$ and phenyl isocyanate in refluxing $p$-xylene without isolation of $\mathbf{1 2 6}$ also gave 131c (61\%) in a single operation. Treatment of 131c with $6 \mathrm{~N} \mathrm{NaOH}$ in refluxing ethanol for $12 \mathrm{~h}$ then furnished 131a in $92 \%$ yield.

When $126 f$ was subjected to thermolysis in $p$-xylene at $138^{\circ} \mathrm{C}$ for $4 \mathrm{~h}$, the indoloquinoline $131 f$ (77\%) was produced exclusively, indicating a preferential formation of 130f for subsequent tautomerization to 131f. The corresponding quinoline $128 f(R=M e)$ was not detected. Direct thermolysis of the reaction mixture of $\mathbf{1 0 3 f}$ and phenyl isocyanate in refluxing $p$-xylene without isolation of $\mathbf{1 2 6 f}$ also afforded $\mathbf{1 3 1 f}(59 \%)$ in a single operation. It was reported that $\mathbf{1 3 1 f}$ could serve as the immediate precursor of 5,11-dimethyl-5H-indolo[2,3$b$ ]quinoline (132f) (eq 10), which was found to display a strong antibacterial, antimycotic, and cytotoxic activity in vitro, as well as significant antitumor properties in vivo. ${ }^{61}$

Similarly, when 126d having a propyl group at the acetylenic terminus was heated either in refluxing $p$-xylene or in $\gamma$-terpinene at $138^{\circ} \mathrm{C}$, the indoloquinoline $131 \mathrm{~d}(89 \%)$ was produced exclusively, in sharp contrast to the ketenimine 104d $(\mathrm{R}=\mathrm{Pr})$ which furnished the quinoline 106d preferentially. In addition, the carbodiimide 126d is thermally less labile than the ketenimine 104d, and a higher temperature is needed to promote the reaction. Treatment of 
103d with phenyl isocyanate in refluxing $p$-xylene without isolation of 126d also afforded 131d directly in a one-step operation in $72 \%$ yield. With $\mathbf{1 2 6}$ b having a sterically very demanding tert-butyl group, thermolysis in refluxing $p$-xylene for $14 \mathrm{~h}$ produced the indoloquinoline $\mathbf{1 3 1 b}$ (76\%). Again, the presence of a tert-butyl group at the acetylenic terminus of $\mathbf{1 2 6} \mathbf{b}$ makes the formation of $\mathbf{1 3 0 b}$ via the concerted intramolecular Diels-Alder reaction unlikely. With a phenyl substituent at the acetylenic terminus of 126e, thermolysis under refluxing benzene $\left(80^{\circ} \mathrm{C}\right)$ for 4 $\mathrm{h}$ was sufficient to induce the transformation to $131 \mathrm{e}^{58}$ in $91 \%$ yield. Direct thermolysis of the reaction mixture of $\mathbf{1 0 3 e}$ and phenyl isocyanate in refluxing benzene without isolation of $\mathbf{1 2 6 e}$ also afforded 131e in $67 \%$ yield.

4-Methoxyphenyl isocyanate was also used for the aza-Wittig reaction with $\mathbf{1 0 3 d}$ and 103e. Thermolysis of the reaction mixtures furnished the indoloquinolines $142 d$ and $142 e^{49 b}$ having a methoxy substituent at the C-2 position (eq 12).

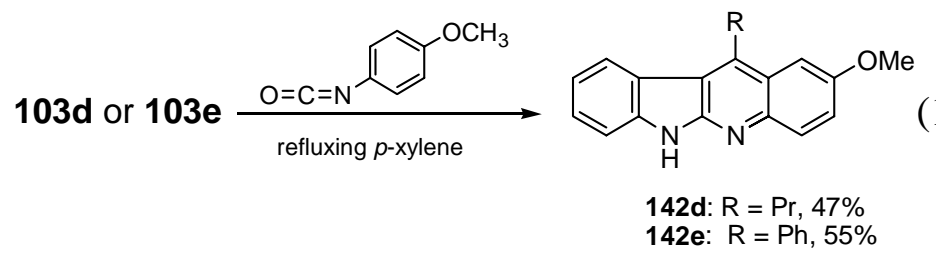

Surprisingly, when 2-methoxyphenyl isocyanate was used for the aza-Wittig reaction with 103d, the thermolysis product was $131 d \mathrm{C}$ - with the loss of the methoxyl group. The indoloquinoline product having a methoxyl substituent at the 4 position was not detected (eq 13). The observation of the loss of the methoxyl group is consistent with the report by Schmittel, Engels and co-workers as outlined in Scheme $30 .^{25 \mathrm{~g}}$ Thermolysis of enyne-carbodiimide $\mathbf{1 2 6 g}$ in toluene in the presence of 1,4-CHD afforded 131g with the loss of one methyl group.

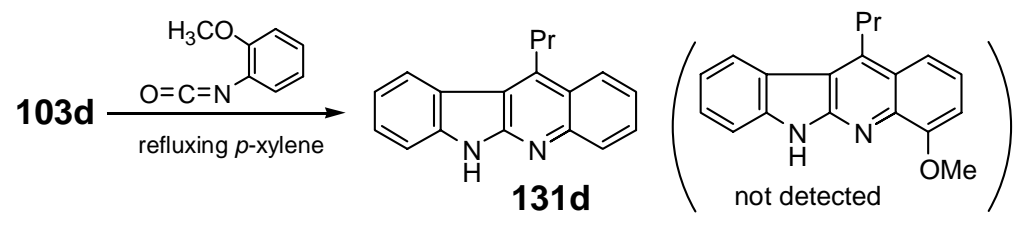



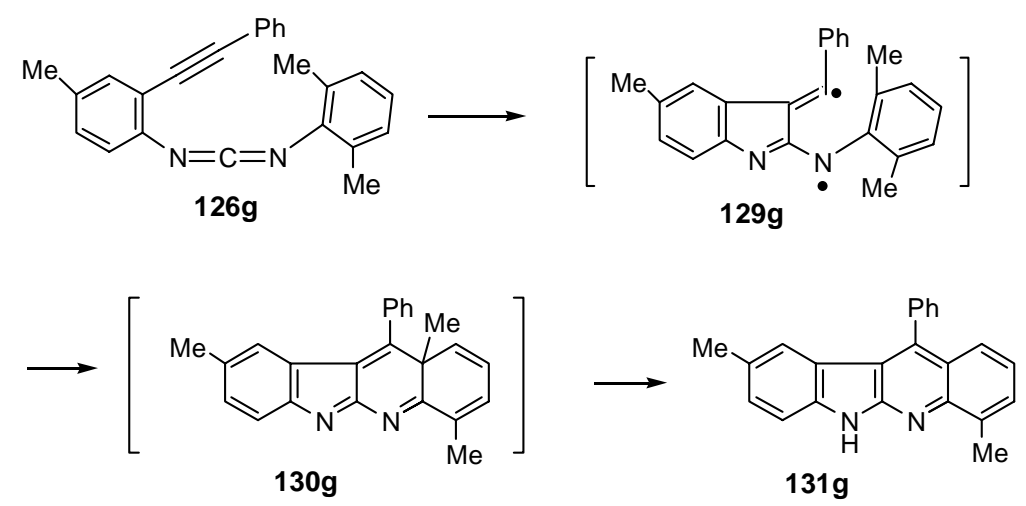

Scheme 30. Thermolysis of Enyne-Carbodiimide 126g.

Treatment of 1,4-phenylene diisocyanate with two equiv of $\mathbf{1 0 3} \mathbf{b}$ for the aza-Wittig reaction produced $143 \mathrm{~b}$ in situ, which on thermolysis in refluxing $p$-xylene furnished a solid product 144 (Scheme 31). A signal at $m / z=470.2464$, corresponding to a rearranged product of 143b, was detected on a high-resolution mass spectrometer. Because of its extremely poor solubility in organic solvents (DMSO, $\mathrm{CF}_{3} \mathrm{CO}_{2} \mathrm{H}, \mathrm{DMF}, \mathrm{MeOH}$, etc.), we were not able to identify its structure. In an analogous study, Quan Zhang of our group synthesized 148 (Scheme 32). ${ }^{25 d}$ The presence of the two $n$-octyl groups in $\mathbf{1 4 8}$ greatly enhances its solubility in organic solvents. However, because the tert-butyl groups in $\mathbf{1 4 3 b}$ are sterically more demanding, it is not clear whether a structure similar to $\mathbf{1 4 8}$ with $\mathrm{R}$ being tert-butyl is possible from thermolysis of $\mathbf{1 4 3 b}$. Another possible structure for 144 is shown in Scheme 33. Tautomerization of 145 $(\mathrm{R}=t-\mathrm{Bu})$ could lead to 149 , which could lead to the linearly fused system 144 .

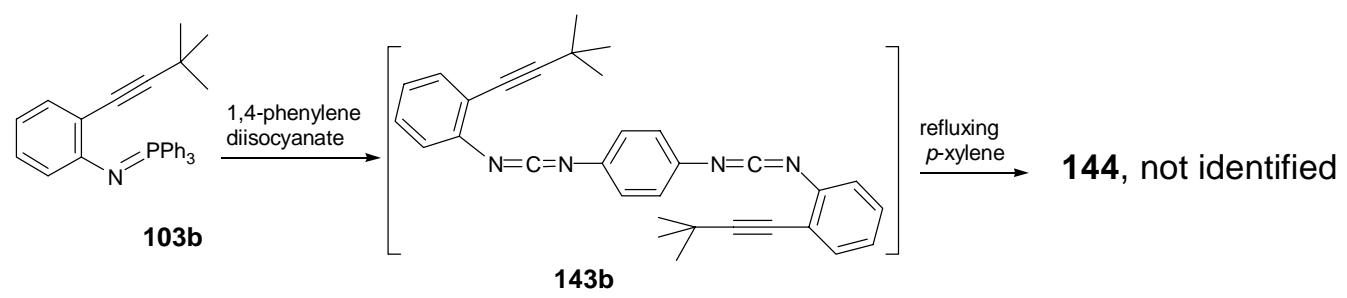

Scheme 31. Thermolysis of $\mathbf{1 4 3 b}$. 

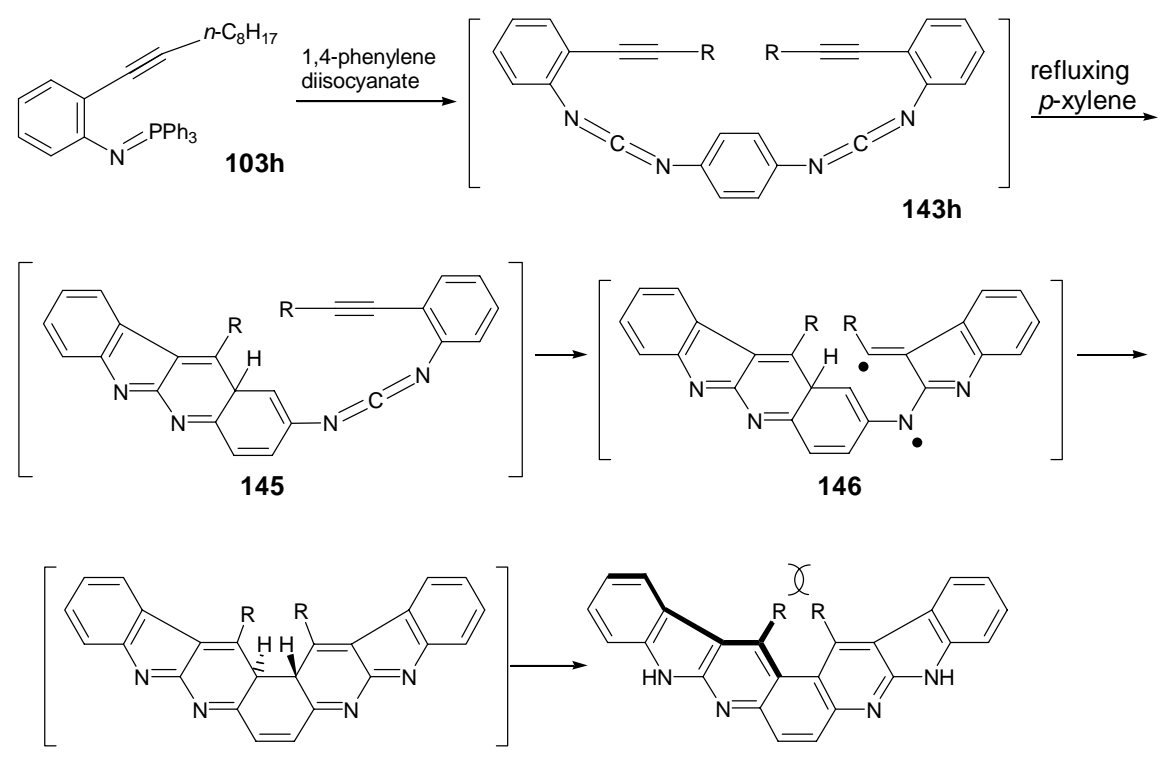

148: $\mathrm{R}=n-\mathrm{C}_{8} \mathrm{H}_{17}, 66 \%$

Scheme 32. Thermolysis of $\mathbf{1 4 3 h}$.

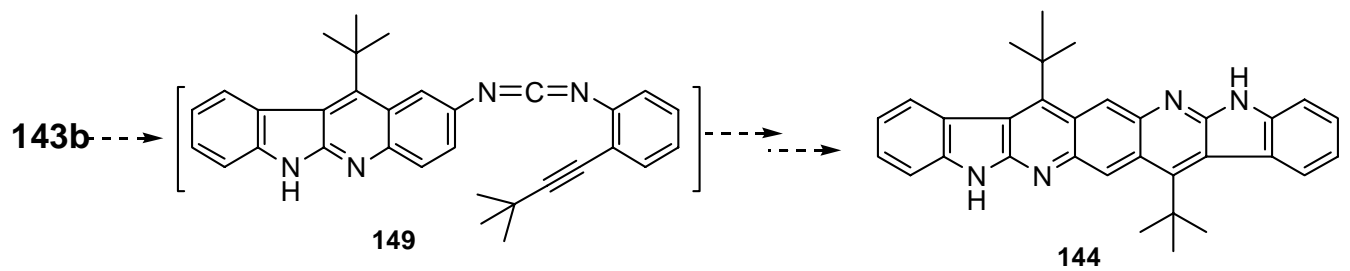

Scheme 33. Proposed Structure of 144.

The structures of $\mathbf{1 2 6}$ and $\mathbf{1 3 1}$ were characterized by spectroscopic methods.

Generally speaking, the characteristic signals for carbodiimides include IR absorptions around $2150-2100 \mathrm{~cm}^{-1}$ for $\mathrm{N}=\mathrm{C}=\mathrm{N}$ and the ${ }^{13} \mathrm{C}$ NMR signal around $\delta 140 \mathrm{ppm}$ for $\mathrm{N}=\mathrm{C}=\mathrm{N}$. For 126d, it showed strong absorptions at 2143 and $2107 \mathrm{~cm}^{-1}(\mathrm{~N}=\mathrm{C}=\mathrm{N})$ in the IR spectrum. The HRMS (m/z 260.1312, $\left.\mathrm{M}^{+}\right)$indicates that it has a molecular formula of $\mathrm{C}_{18} \mathrm{H}_{16} \mathrm{~N}_{2}$. The ${ }^{1} \mathrm{H}$ NMR spectrum of 126d showed the characteristic propyl signals at $\delta 2.10(2 \mathrm{H}, \mathrm{t}, J=7.2 \mathrm{~Hz}), 1.46(2$ $\mathrm{H}$, sextet, $J=7.3 \mathrm{~Hz}$ ) and $0.93(3 \mathrm{H}, \mathrm{t}, J=7.3 \mathrm{~Hz})$ and signals for nine aromatic hydrogens between $\delta 7.44$ and 7.08. The tentative chemical-shift assignments for the ${ }^{13} \mathrm{C}$ NMR spectrum of 126d are as following: $\delta 139.16\left(\mathrm{C}_{1}\right), 138.72\left(\mathrm{C}_{8}\right), 133.65\left(\mathrm{C}_{7}\right), 133.01\left(\mathrm{C}_{3}\right), 129.25\left(\mathrm{C}_{10}\right), 128.39$ 
$\left(\mathrm{C}_{5}\right), 125.12\left(\mathrm{C}_{4}\right), 125.05\left(\mathrm{C}_{6}\right), 124.25\left(\mathrm{C}_{11}\right), 124.19\left(\mathrm{C}_{9}\right), 120.78\left(\mathrm{C}_{2}\right), 98.70\left(\mathrm{C}_{13}\right), 76.87\left(\mathrm{C}_{12}\right)$, $21.69\left(\mathrm{C}_{14}\right), 21.53\left(\mathrm{C}_{15}\right), 13.40\left(\mathrm{C}_{16}\right)$.

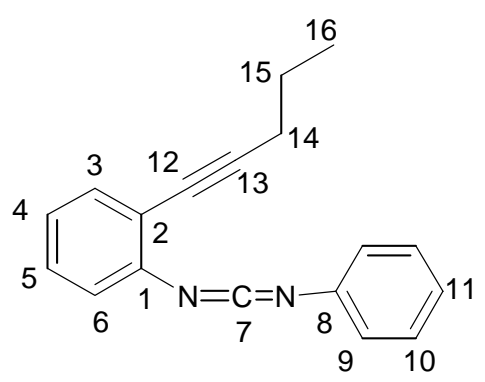

Figure 12. Numbering of 126d.

The molecular ion of the $6 H$-indolo[2,3-b]quinoline 131d has the same mass as the starting material 126d $\left(\mathrm{m} / \mathrm{z} 260, \mathrm{M}^{+}\right)$. The elemental also analysis indicated its molecular formula as $\mathrm{C}_{18} \mathrm{H}_{16} \mathrm{~N}_{2}$. The IR spectrum showed the $\mathrm{N}-\mathrm{H}$ absorption at $3455 \mathrm{~cm}^{-1}$. In the ${ }^{1} \mathrm{H}$ NMR spectrum, 131d has one less aromatic hydrogen, but one extra N-H signal at $\delta 12.23(1 \mathrm{H}$, br s) ppm compared with the starting material 126d. The benzylic methylene group exhibited a triplet at $\delta 3.65 \mathrm{ppm}$, which was shifted downfield. Except the three propyl carbons, all other carbon signals are located in the aromatic region. The tentative assignments of NMR signals are listed in Table 3 based on the ${ }^{1} \mathrm{H}$ and ${ }^{13} \mathrm{C}$ APT NMR spectra.

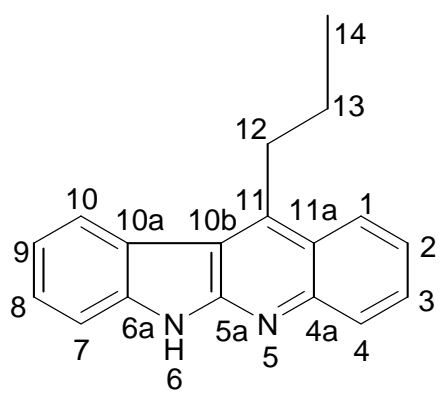

Figure 13. Numbering of 131d. 


\begin{tabular}{|c|c|c|c|c|c|c|c|}
\hline No. & 1 & 2 & 3 & 4 & $4 a$ & $5 a$ & 6 \\
\hline $\mathrm{CHn}$ & $\mathrm{CH}$ & $\mathrm{CH}$ & $\mathrm{CH}$ & $\mathrm{CH}$ & $\mathrm{C}$ & $\mathrm{C}$ & $\mathrm{NH}$ \\
\hline $\mathrm{H}$ & 8.22 & $7.6-7.48$ & $7.6-7.48$ & 8.3 & & & 12.23 \\
\hline $\mathrm{C}$ & 128.71 & 123.41 & 124.17 & 127.45 & 146.26 & 153.44 & \\
\hline \hline $\mathrm{No}$. & $6 \mathrm{a}$ & 7 & 8 & 9 & 10 & $10 \mathrm{a}$ & $10 \mathrm{~b}$ \\
\hline $\mathrm{CHn}$ & $\mathrm{C}$ & $\mathrm{CH}$ & $\mathrm{CH}$ & $\mathrm{CH}$ & $\mathrm{CH}$ & $\mathrm{C}$ & $\mathrm{C}$ \\
\hline $\mathrm{H}$ & & 8.17 & $7.6-7.48$ & 7.31 & 7.77 & & \\
\hline $\mathrm{C}$ & 144.31 & 110.93 & 127.04 & 119.99 & 122.67 & 121.39 & 116.63 \\
\hline \hline $\mathrm{No}$ & 11 & $11 \mathrm{a}$ & 12 & 13 & 14 & & \\
\hline $\mathrm{CHn}$ & $\mathrm{C}$ & $\mathrm{C}$ & $\mathrm{CH} 2$ & $\mathrm{CH} 2$ & $\mathrm{CH} 3$ & & \\
\hline $\mathrm{H}$ & & & 3.65 & 1.98 & 1.24 & & \\
\hline $\mathrm{C}$ & 141.38 & 123.41 & 30.93 & 22.92 & 14.7 & & \\
\hline
\end{tabular}

Table 3. Tentative Chemical-Shift Assignments of NMR Spectra of 131d.

\subsubsection{Summary}

Thermolysis of the carbodiimides 126 represents a new way of generating biradicals from unsaturated molecules having two nitrogen atoms in the conjugated system. The cascade sequence outlined in Scheme 28 also provides a general and efficient pathway to $6 H$-indolo[2,3$b$ ]quinolines. The possibility of placing a wide variety of substituents at various positions of the $6 H$-indolo[2,3-b]quinoline structure by selecting suitable fragments for assembly is an especially attractive feature of this synthetic route.

\subsection{Synthesis of $6 \mathrm{H}$-Indolo[2,3-b][1,6]naphthyridines and Related Compounds as the 5-Aza}

\section{Analogues of Ellipticine Alkaloids}

\subsubsection{General Strategy}

Ellipticine 150 and 9-methoxyellipticine $\mathbf{1 5 1}$ are two naturally occurring $6 H$-pyrido[4,3$b$ carbazole alkaloids isolated from the leaves of Ochrosia elliptica Labill (family Apocynaceae) (Figure 13 ). ${ }^{65}$ The discovery of their antitumor activities in $1967^{66}$ has led to an explosion of synthetic, biological, and pharmacological studies of ellipticine and its derivatives. ${ }^{67}$ Several 
ellipticine derivatives have been used in clinical trials. ${ }^{67 a-c}$ More recently, 5-methyl-5Hindolo[2,3-b]quinoline 132a, an indoloquinoline alkaloid isolated from the West African plant Cryptolepis sanguinolenta, ${ }^{68}$ was reported to display a strong antiplasmodial activity. ${ }^{69}$

Similarly, $\mathbf{1 3 2 f}$ having a methyl substituent at the $\mathrm{C} 11$ position exhibited a strong
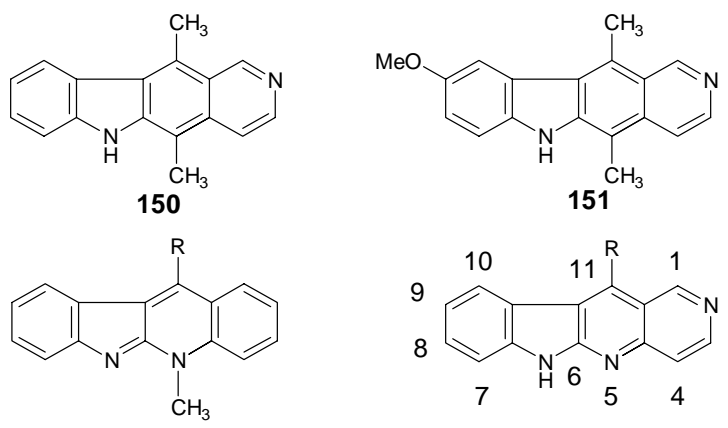

132a: $\mathrm{R}=\mathrm{H}$ 132f: $R=M e$

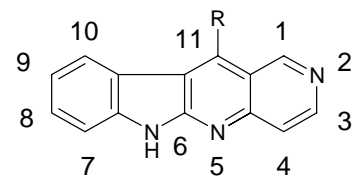

152

Figure 14. Structure Comparison.

antibacterial, antimycotic, and cytotoxic activity in vitro as well as significant antitumor properties in vivo. ${ }^{61 a}$ Methylation of $6 \mathrm{H}$-indolo[2,3-b]quinolines $\mathbf{1 3 1}$ with dimethyl sulfate followed by treatment with sodium hydroxide led to $\mathbf{1 3 2}$ directly (eq 11). ${ }^{25 b, 61,63}$ The interesting biological activities of ellipticines and indoloquinolines prompted us to develop a new synthetic route to the $6 H$-indolo[2,3-b][1,6]naphthyridines 152 , which could be regarded as the 5-aza analogues of ellipticines merging the heterocyclic frameworks of both ellipticine and indoloquinoline. Only one synthetic route involving a seven-step synthesis of 3-acetyl-4(methylamino)pyridine from 3-acetylpyridine followed by condensation with oxindole to form 5,11-dimethyl-5H-indolo[2,3- $b][1,6]$ naphthyridine as the 5-aza analogue of ellipticine had been reported previously (Scheme 34). ${ }^{70}$ 



Scheme 34. Synthesis of 5,11-Dimethyl-5H-indolo[2,3-b][1,6]naphthyridine.

The efficient synthetic route to the $6 H$-indolo[2,3-b]quinolines 131 via thermolysis of the benzoenynyl carbodiimides $\mathbf{1 2 6}$ outlined in Scheme 28 could be adopted for the synthesis of 152 and related compounds. ${ }^{25 \mathrm{~d}}$ We envisioned that by replacing the phenyl group in the iminophosphorane with a pyridyl group, the similar synthetic sequence could lead to a variety of indolonaphthyridines as the 5-aza analogues of ellipticines and the much less studied isoellipticines ${ }^{71}$ in which the pyridine nitrogen is at a different ring D position.

\subsubsection{Results and Discussion}

Treatment of $\mathbf{1 0 2 f}$ with triphosgene provided 2-(1-propynyl)phenyl isocyanate $\mathbf{1 6 3}$ in 96\% yield (eq 14). ${ }^{72}$ The iminophosphorane 164 was prepared by treatment of 3-aminopyridine with dibromotriphenylphosphorane $\left(\mathrm{Ph}_{3} \mathrm{PBr}_{2}\right)$ in $76 \%$ yield in a single step (eq 15). ${ }^{73}$ 




The aza-Wittig reaction between $\mathbf{1 6 3}$ and $\mathbf{1 6 4}$ produced in situ the benzoenynyl carbodiimides 165 (Scheme 35). Thermolysis of 165 under refluxing $p$-xylene then furnished the



Scheme 35. Thermolysis of of Benzoenynyl Carbodiimides 165.

$6 H$-indolo[2,3-b][1,5]naphthyridines $\mathbf{1 6 9}$ as the major isomer and the $10 H$-indolo[2,3$b][1,7]$ naphthyridines $\mathbf{1 7 0}$ as the minor isomer. Apparently, cyclization of $\mathbf{1 6 5}$ furnished the formal Diels-Alder adducts 167 preferentially, leading to 169 as the major isomer. The reason for such a preference is not clear at this time. The structures of $\mathbf{1 6 9}$ and $\mathbf{1 7 0}$ represent two rare heterocyclic systems that could be regarded as the aza analogues of isoellipticines.

There was only one earlier report of a indolonaphthyridine derivative having the 
heterocyclic structure of $\mathbf{1 6 9} .^{74}$ The indolonaphthyridine $\mathbf{1 7 0}$ was previously synthesized by condensation of 4-acetyl-3-pivaloylaminopyridine (171) with oxindole (Scheme 36). ${ }^{75}$
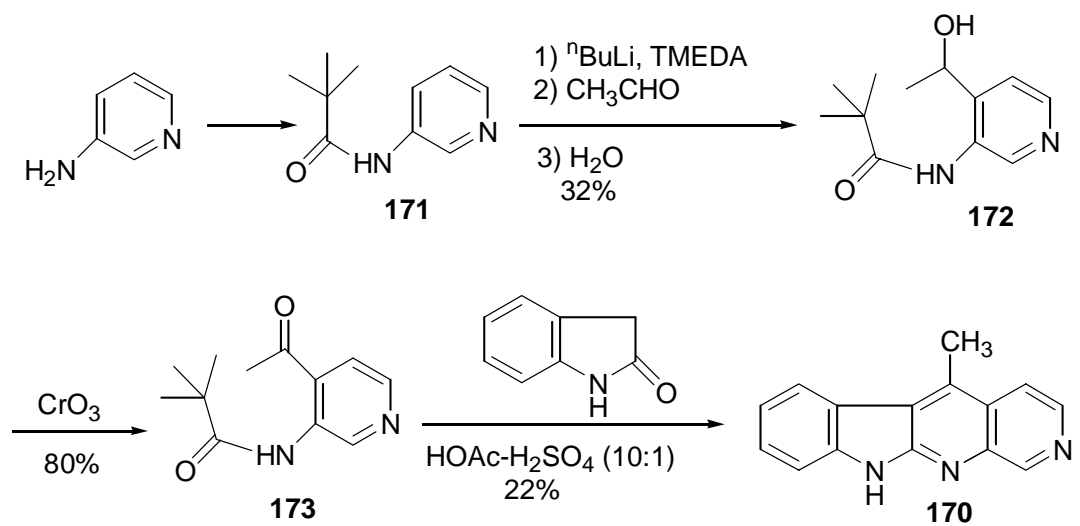

Scheme 36. Synthesis of Indolonaphthyridine 170.

Similarly, Quan Zhang successfully synthesized 152 by treatment of 163 and its analogues with $N$-(4-pyridylimino)triphenylphosphorane. ${ }^{25 e}$ It is worth noting that the synthetic sequence outlined in Scheme 35 allows easy introduction of a variety substituents as the R group at the $\mathrm{C} 11$ position of $\mathbf{1 6 9}$ or at the $\mathrm{C} 5$ position of $\mathbf{1 7 0}$ and similarly at the C11 position of $\mathbf{1 5 2}$ by using $N$-(4-pyridylimino)triphenylphosphorane for condensation.

The structures of 169 and 170 were characterized by spectroscopic methods. For 169 , both elemental analysis and HRMS $\left(\mathrm{m} / \mathrm{z} 233.0954, \mathrm{M}^{+}\right)$indicated its molecular formula as $\mathrm{C}_{15} \mathrm{H}_{11} \mathrm{~N}_{3}$. The ${ }^{1} \mathrm{H}$ NMR spectrum of $\mathbf{1 6 9}$ clearly showed nine aromatic hydrogens and a methyl group at $\delta 3.37\left(3 \mathrm{H}\right.$, s) ppm, which was shifted downfield. The ${ }^{13} \mathrm{C}$ NMR spectrum of $\mathbf{1 6 9}$ indicated fourteen carbons in the aromatic region and one methyl group. The tentative assignments of the NMR signals are listed in Table 4 based on the ${ }^{1} \mathrm{H}$ and ${ }^{13} \mathrm{C}$ APT NMR spectra. 


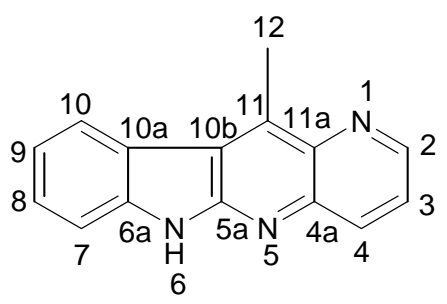

Figure 15. Numbering of 169.

\begin{tabular}{|c|c|c|c|c|c|c|}
\hline No. & 2 & 3 & 4 & $4 a$ & $5 a$ & 6 \\
\hline $\mathrm{CHn}$ & $\mathrm{CH}$ & $\mathrm{CH}$ & $\mathrm{CH}$ & $\mathrm{C}$ & $\mathrm{C}$ & $\mathrm{NH}$ \\
\hline $\mathrm{H}$ & 8.95 & 7.62 & 8.33 & & & 9.73 \\
\hline $\mathrm{C}$ & 146.2 & 124 & 128.1 & 139 & 1521 & \\
\hline \hline $\mathrm{No}$. & $6 \mathrm{a}$ & 7 & 8 & 9 & 10 & \\
\hline $\mathrm{CHn}$ & $\mathrm{C}$ & $\mathrm{CH}$ & $\mathrm{CH}$ & $\mathrm{CH}$ & $\mathrm{CH}$ & \\
\hline $\mathrm{H}$ & & 7.5 & 7.35 & 7.55 & 8.3 & \\
\hline $\mathrm{C}$ & 140 & 110.9 & 135 & 120 & 123.5 & \\
\hline \hline $\mathrm{No}$. & $10 \mathrm{a}$ & $10 \mathrm{~b}$ & 11 & $11 \mathrm{a}$ & 12 & \\
\hline $\mathrm{CHn}$ & $\mathrm{C}$ & $\mathrm{C}$ & $\mathrm{C}$ & $\mathrm{C}$ & $\mathrm{CH} 3$ & \\
\hline $\mathrm{H}$ & & & & & 3.37 & \\
\hline $\mathrm{C}$ & 121 & 118.6 & 141.7 & 141.3 & 13.4 & \\
\hline
\end{tabular}

Table 4. Tentative Chemical-Shift Assignments of NMR Spectra of $\mathbf{1 6 9}$.

Compound $\mathbf{1 7 0}$ is the isomer of $\mathbf{1 6 9}$ and the signal at $\delta 9.32(1 \mathrm{H}, \mathrm{s}) \mathrm{ppm}$ in its ${ }^{1} \mathrm{H}$ NMR spectrum distinguished $\mathbf{1 7 0}$ from 169. The tentative chemical-shifts assignments are listed in Table 5 based on the ${ }^{1} \mathrm{H}$ and ${ }^{13} \mathrm{C}$ APT NMR spectra.



Figure 16. Numbering of $\mathbf{1 7 0 .}$ 


\begin{tabular}{|c|c|c|c|c|c|c|}
\hline No. & 1 & 3 & 4 & $4 a$ & 5 & $5 a$ \\
\hline $\mathrm{CHn}$ & $\mathrm{CH}$ & $\mathrm{CH}$ & $\mathrm{CH}$ & $\mathrm{C}$ & $\mathrm{C}$ & $\mathrm{C}$ \\
\hline $\mathrm{H}$ & 9.32 & 8.51 & 8.21 & & & \\
\hline $\mathrm{C}$ & 151.7 & 139.6 & 120.1 & 120.4 & 137.8 & 117 \\
\hline \hline $\mathrm{No}$. & $5 \mathrm{~b}$ & 6 & 7 & 8 & 9 & \\
\hline $\mathrm{CHn}$ & $\mathrm{C}$ & $\mathrm{CH}$ & $\mathrm{CH}$ & $\mathrm{CH}$ & $\mathrm{CH}$ & \\
\hline $\mathrm{H}$ & & 7.54 & 7.32 & 7.6 & 8.39 & \\
\hline $\mathrm{C}$ & 119.1 & 124.5 & 120.1 & 128.7 & 111 & \\
\hline \hline $\mathrm{No}$ & $9 \mathrm{a}$ & 10 & $10 \mathrm{a}$ & $11 \mathrm{a}$ & 12 & \\
\hline $\mathrm{CHn}$ & $\mathrm{C}$ & $\mathrm{NH}$ & $\mathrm{C}$ & $\mathrm{C}$ & $\mathrm{CH} 3$ & \\
\hline $\mathrm{H}$ & & 11.97 & & & 3.18 & \\
\hline $\mathrm{C}$ & 142 & & 152.8 & 126.3 & 14.4 & \\
\hline
\end{tabular}

Table 5. Tentative Chemical-Shift Assignments of NMR Spectra of $\mathbf{1 7 0 .}$

\subsubsection{Summary}

A new and efficient synthetic pathway to indolonaphthyridines has been developed. The synthetic route is convergent and allows easy placement of a variety of substituents around the periphery of the heterocyclic ring system. The structures of indolonaphthyridines resemble those of ellipticine alkaloids, making them good candidates as DNA intercalating agents with potentially interesting biological activities. 


\section{Conclusion}

The thermal behaviors of enyne-ketenimines and enyne-carbodiimides are very similar to those of the corresponding enyne-allenes and enyne-ketenes. There are two competing pathways for the biradical cyclization reaction mainly depending on the nature of substitution at the alkyne terminus. On the bases of our preliminary studies, the enyne-ketenimines and enynecarbodiimides without substitution at the alkyne terminus tend to undergo Myers-like cycloaromatization reactions and give the quinoline derivatives as the major products. With a small and unbranched alkyl group attached to the alkyne terminus, such as methyl and propyl groups, the benzoenynyl ketenimines favor the Myers-like cycloaromatization. On the other hand, the benzoenynyl carbodiimides are thermally more inert and favor the formation of biradicals 129. The biradical-forming reactions of enyne-ketenimines and enyne-carbodiimides provide efficient synthetic routes to: (i) the quinolines and $5 H$-benzo[b]carbazoles 109 via thermolysis of benzoenynyl ketenimines; (ii) $6 H$-indolo[2,3- $b$ ]quinolines $\mathbf{1 3 1}$ via thermolysis of benzoenynyl carbodiimides and (iii) indolonaphthyridines. In addition, the flexible nature of the synthesis plan should provide access to a diverse array of alkaloids. The methodology described herein could also find potential applications for the synthesis of other biologically interesting heterocycles, such as benzo[f]pyridoindoles ${ }^{76}$ and pyridopyrrolo[ $[5,4-b]$ quinolines ${ }^{77,78}$ as outlined in Scheme 37. 

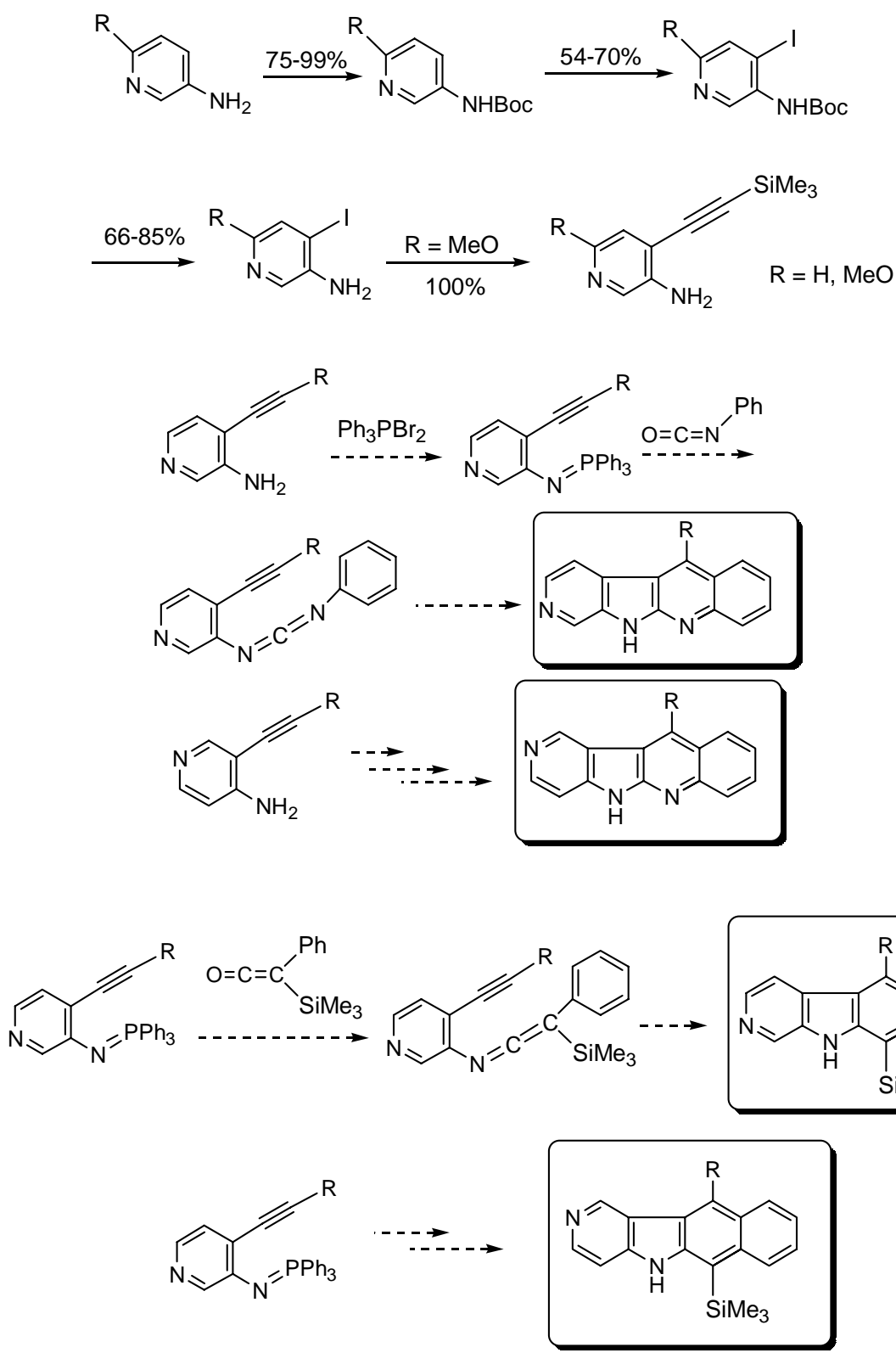

Scheme 37. Potential Applications in the Synthesis of Benzo[f]pyridoindoles and Pyridopyrroloquinolines. 


\section{Experimental Section}

General procedures. Diethyl ether and tetrahydrofuran (THF) were distilled from benzophenone ketyl prior to use. Pyridine and triethylamine were distilled over $\mathrm{CaH}_{2}$ prior to use. The 2-(1-alkynyl)anilines 102 (83-100\% yield) ${ }^{48}$ iminophosphoranes $103^{49 a}$ and $164^{67}$ were prepared according to the reported procedure. Diphenylketene was prepared by dehydrochlorination of diphenylacetyl chloride as reported previously. ${ }^{50}$ 2-Iodoaniline was purchased from Oakwood Products, Inc. and was used as received. 1-Alkynes were obtained from Farchan Laboratories, Inc. and were used without further purification.

Dibromotriphenylphosphorane $\left(\mathrm{Ph}_{3} \mathrm{PBr}_{2}\right)$, phenylacetyl chloride, diphenylacetyl chloride, triphosgene, 3-aminopyridine, $\mathrm{Pd}\left(\mathrm{PPh}_{3}\right)_{2} \mathrm{Cl}_{2}, 1$,4-CHD, phenyl isocyanate, 4-methoxyphenyl isocyanate, 1,4-phenylene diisocyanate, $\mathrm{Pd}\left(\mathrm{PPh}_{3}\right)_{4}, p$-xylene (anhydrous), $N, N$ dimethylformamide (DMF), $N, N$-diisopropylethylamine, and $\gamma$-terpinene were purchased from Aldrich. The kinetic studies were carried out in a constant-temperature bath $\left( \pm 0.5^{\circ} \mathrm{C}\right)$ and error bounds are quoted as 20 . Melting points were uncorrected. ${ }^{1} \mathrm{H}(270 \mathrm{MHz})$ and ${ }^{13} \mathrm{C}(67.9 \mathrm{MHz})$ NMR spectra were recorded in $\mathrm{CDCl}_{3}$ on a JEOL-GX-270 NMR spectrometer using $\mathrm{CHCl}_{3}\left({ }^{1} \mathrm{H}\right.$ $\delta$ 7.26) or $\mathrm{CDCl}_{3}\left({ }^{13} \mathrm{C} \delta\right.$ 77.00) as the internal standard. IR spectra were taken on Perkin-Elmer 1600 FT-IR spectrometer. Mass-spectra were obtained on Hewlett Packard 5970B GC/MSD instrument at $70 \mathrm{eV}$.

All reactions were conducted in oven-dried $\left(120^{\circ} \mathrm{C}\right)$ glassware under a nitrogen atmosphere.

2-(1-Propynyl)aniline (102f). A suspension of $2.190 \mathrm{~g}$ of 2-iodoaniline (10.0 mmol), $0.190 \mathrm{~g}$ of copper(I) iodide $(1.00 \mathrm{mmol})$, and $0.562 \mathrm{~g}$ of $\mathrm{Pd}\left(\mathrm{PPh}_{3}\right)_{2} \mathrm{Cl}_{2}(0.800 \mathrm{mmol})$ in $50 \mathrm{~mL}$ of triethylamine was cooled to $-78{ }^{\circ} \mathrm{C}$ under a nitrogen atmosphere and degassed by freeze-pump- 
thaw. After the reaction mixture was allowed to warm to $\mathrm{rt}, 672 \mathrm{~mL}$ of gaseous propyne (27 mmol) was introduced with a gas-tight syringe, and the resulting mixture was stirred at $\mathrm{rt}$ for 27 h. The reaction mixture was then concentrated, and $200 \mathrm{~mL}$ of diethyl ether was added. The solid suspension was removed by filtration, and the filtrate was washed with water, dried over $\mathrm{MgSO}_{4}$, and concentrated. The residue was purified by column chromatography (silica gel/10\% diethyl ether in hexanes) to furnish $1.310 \mathrm{~g}$ of $\mathbf{1 0 2 f}(10.0 \mathrm{mmol}, 100 \%)$ as a yellow oil: IR (neat) 3469, 3374, 2044, 1614, $749 \mathrm{~cm}^{-1} ;{ }^{1} \mathrm{H} \delta 7.25(1 \mathrm{H}, \mathrm{dd}, J=8.2$ and $1.5 \mathrm{~Hz}), 7.08(1 \mathrm{H}, \mathrm{td}, J=7.7$ and 1.5 Hz), 6.69-6.64 (2 H, m), 4.18 (2 H, br s), $2.11(3 \mathrm{H}, \mathrm{s}) ;{ }^{13} \mathrm{C} \delta 147.61,131.92,128.74$, 117.76, 114.10, 108.85, 90.96, 76.13, 4.51; MS m/z $131\left(\mathrm{M}^{+}\right), 130,103,77$.

2-Ethynyl- $N$-(triphenylphosphoranylidene)benzenamine (103a). ${ }^{49 b}$ Iminophosphorane 103a was prepared according to the reported procedure. ${ }^{49 \mathrm{a}}$ To $3.798 \mathrm{~g}$ of $\mathrm{Ph}_{3} \mathrm{PBr}_{2}$ (9.00 mmol) was added a mixture of $1.053 \mathrm{~g}$ of 2-ethynylaniline $(\mathbf{1 0 2 a}, 9.00 \mathrm{mmol})$ and $2.5 \mathrm{~mL}$ of anhydrous triethylamine in $100 \mathrm{~mL}$ of anhydrous benzene via cannula under a nitrogen atmosphere. The reaction mixture was heated under reflux for 4 hours. The white triethylammonium bromide precipitate was removed by filtration, and the filtrate was concentrated in vacuo. The residue was purified through a short column (silica gel/40-60\% diethyl ether in hexanes) to furnish 2.239 $\mathrm{g}(5.94 \mathrm{mmol}, 66 \%)$ of $\mathbf{1 0 3 a}$ as colorless crystals: mp $142-143{ }^{\circ} \mathrm{C}$ (lit. $\left.{ }^{49 \mathrm{~b}} 141^{\circ} \mathrm{C}\right)$; IR (KBr) 3279 , 2094, 1584, 1479, 1436, 1368, 1110, 750, $715 \mathrm{~cm}^{-1} ;{ }^{1} \mathrm{H} \delta$ 7.88-7.80 (6 H, m), 7.56-7.39 (10 H, m), $6.87(1 \mathrm{H}, \mathrm{td}, J=7.7$ and $1.6 \mathrm{~Hz}), 6.59(1 \mathrm{H}, \mathrm{t}, J=7.4 \mathrm{~Hz}), 6.47(1 \mathrm{H}, \mathrm{d}, J=8.1 \mathrm{~Hz}), 3.34(1$ $\mathrm{H}, \mathrm{s}) ;{ }^{13} \mathrm{C} \delta 153.57,133.57,132.61(\mathrm{~d}, J=9.8 \mathrm{~Hz}), 131.63(\mathrm{~d}, J=2.6 \mathrm{~Hz}), 130.92(\mathrm{~d}, J=99.7$ Hz), 128.82, 128.49 (d, $J=11.9 \mathrm{~Hz}), 121.19(\mathrm{~d}, J=9.8 \mathrm{~Hz}), 117.23(\mathrm{~d}, J=23.2 \mathrm{~Hz}), 116.80$, $85.12,79.22$. 
2-(3,3-Dimethyl-1-butynyl)- $N$-(triphenylphosphoranylidene)benzenamine (103b). The same procedure was repeated as described for 103a except that a mixture of $1.557 \mathrm{~g}$ of $2-(3,3-$ dimethyl-1-butynyl)aniline (102b, $9.00 \mathrm{mmol}), 3.798 \mathrm{~g}$ of $\mathrm{Ph}_{3} \mathrm{PBr}_{2}(9.00 \mathrm{mmol})$, and $2.5 \mathrm{~mL}$ of anhydrous triethylamine in $100 \mathrm{~mL}$ of anhydrous benzene was heated under reflux for 4 hours to afford $3.352 \mathrm{~g}$ of $\mathbf{1 0 3 b}(7.74 \mathrm{mmol}, 86 \%)$ as colorless crystals: mp $111-112^{\circ} \mathrm{C}$; IR (KBr) 1583 , $1477,1438,1347,1112,748,714,694 \mathrm{~cm}^{-1} ;{ }^{1} \mathrm{H} \delta$ 7.91-7.82 (6 H, m), 7.56-7.40 (9 H, m), 7.32 (1 $\mathrm{H}, \mathrm{dt}, J=7.7$ and $2.1 \mathrm{~Hz}), 6.79(1 \mathrm{H}, \mathrm{tm}, J=7.7$ and $1.7 \mathrm{~Hz}), 6.57(1 \mathrm{H}, \mathrm{tt}, J=7.4$ and $1 \mathrm{~Hz})$, $6.44(1 \mathrm{H}, \mathrm{dt}, J=7.9$ and $1.1 \mathrm{~Hz}), 1.41(9 \mathrm{H}, \mathrm{s}) ;{ }^{13} \mathrm{C} \delta 152.13,133.19,132.72(\mathrm{~d}, J=9.3 \mathrm{~Hz})$, $131.48(\mathrm{~d}, J=2.6 \mathrm{~Hz}), 131.45(\mathrm{~d}, J=100.0 \mathrm{~Hz}), 128.37(\mathrm{~d}, J=12.4 \mathrm{~Hz}), 127.55,121.27(\mathrm{~d}, J=$ $8.8 \mathrm{~Hz}), 119.34(\mathrm{~d}, J=22.8 \mathrm{~Hz}), 117.01,100.28,79.78,31.48,28.24$.

2-[(Trimethylsilyl)ethynyl]- $N$-(triphenylphosphoranylidene)benzenamine (103c). The same procedure was repeated as described for 103a except that a mixture of $1.890 \mathrm{~g}$ of 2[(trimethylsilyl)ethynyl]aniline (102c, $10.0 \mathrm{mmol}), 4.220 \mathrm{~g}$ of $\mathrm{Ph}_{3} \mathrm{PBr}_{2}(10.0 \mathrm{mmol})$, and $2.8 \mathrm{~mL}$ of anhydrous triethylamine in $100 \mathrm{~mL}$ of anhydrous benzene was heated under reflux for 4 hours to afford $3.323 \mathrm{~g}$ of $\mathbf{1 0 3 c}(7.40 \mathrm{mmol}, 74 \%)$ as colorless crystals: $\mathrm{mp} 107-108^{\circ} \mathrm{C}$; $\mathrm{IR}(\mathrm{KBr})$ 2146, 1583, 1475, 1437, 1348, 1108, 870, 741, 714, $691 \mathrm{~cm}^{-1} ;{ }^{1} \mathrm{H} \delta$ 7.88-7.80 (6 H, m), 7.56-7.36 $(10 \mathrm{H}, \mathrm{m}), 6.83(1 \mathrm{H}, \mathrm{ddd}, J=7.7,7.3$, and $1.7 \mathrm{~Hz}), 6.56(1 \mathrm{H}, \mathrm{t}, J=7.4 \mathrm{~Hz}), 6.44(1 \mathrm{H}, \mathrm{d}, J=$ $7.9 \mathrm{~Hz}), 0.30(9 \mathrm{H}, \mathrm{s}) ;{ }^{13} \mathrm{C} \delta 153.29,133.67,132.72(\mathrm{~d}, J=9.8 \mathrm{~Hz}), 131.61(\mathrm{~d}, J=2.6 \mathrm{~Hz})$, $131.16(\mathrm{~d}, J=100.5 \mathrm{~Hz}), 128.69,128.47(\mathrm{~d}, J=11.9 \mathrm{~Hz}), 121.27(\mathrm{~d}, J=9.3 \mathrm{~Hz}), 118.31(\mathrm{~d}, J=$ 23.3 Hz), 116.89, 106.86, 95.48, 0.44.

2-(1-Pentynyl)- $N$-(triphenylphosphoranylidene)benzenamine (103d). The same procedure was repeated as described for 103a except that a mixture of $1.590 \mathrm{~g}$ of 2-(1-pentynyl)aniline (102d, $10.0 \mathrm{mmol}), 4.220 \mathrm{~g}$ of $\mathrm{Ph}_{3} \mathrm{PBr}_{2}(10.0 \mathrm{mmol})$, and $2.8 \mathrm{~mL}$ of anhydrous triethylamine in 
$100 \mathrm{~mL}$ of anhydrous benzene was heated under reflux for 4 hours to afford $3.897 \mathrm{~g}$ of $\mathbf{1 0 3 d}$ (9.30 mmol, 93\%) as colorless crystals: $\mathrm{mp} 141-142^{\circ} \mathrm{C}$; IR (KBr) 2136, 1582, 1476, 1438, 1348, $1109,749,719,693 \mathrm{~cm}^{-1} ;{ }^{1} \mathrm{H} \delta$ 7.88-7.80 (6 H, m), 7.55-7.40 (9 H, m), $7.33(1 \mathrm{H}, \mathrm{dt}, J=7.7$ and $2.0 \mathrm{~Hz}), 6.81(1 \mathrm{H}, \mathrm{td}, J=7.7 \mathrm{and} 1.7 \mathrm{~Hz}), 6.58(1 \mathrm{H}, \mathrm{t}, J=7.4 \mathrm{~Hz}), 6.48(1 \mathrm{H}, \mathrm{d}, J=7.9 \mathrm{~Hz})$,

$2.51(2 \mathrm{H}, \mathrm{d}, J=7.1 \mathrm{~Hz}), 1.71(2 \mathrm{H}$, sextet, $J=7.3 \mathrm{~Hz}), 1.08(3 \mathrm{H}, \mathrm{t}, J=7.3 \mathrm{~Hz}) ;{ }^{13} \mathrm{C} \delta 152.38$, 132.92, 132.69 (d, $J=9.3 \mathrm{~Hz}), 131.51(\mathrm{~d}, J=2.6 \mathrm{~Hz}), 131.36(\mathrm{~d}, J=100.5 \mathrm{~Hz}), 128.40(\mathrm{~d}, J=$ $11.9 \mathrm{~Hz}), 127.60,121.45(\mathrm{~d}, J=9.3 \mathrm{~Hz}), 119.36(\mathrm{~d}, J=22.3 \mathrm{~Hz}), 117.04,92.19,81.55,22.62$, $22.10,13.82$.

2-(Phenylethynyl)- $N$-(triphenylphosphoranylidene)benzenamine (103e). The same procedure was repeated as described for 103a except that a mixture of $1.930 \mathrm{~g}$ of 2 (phenylethynyl)aniline (102e, $10.0 \mathrm{mmol}), 4.220 \mathrm{~g}$ of $\mathrm{Ph}_{3} \mathrm{PBr}_{2}(10.0 \mathrm{mmol})$, and $2.8 \mathrm{~mL}$ of anhydrous triethylamine in $100 \mathrm{~mL}$ of anhydrous benzene was heated under reflux for 4 hours to afford $4.124 \mathrm{~g}$ of $\mathbf{1 0 3 e}(9.10 \mathrm{mmol}, 91 \%)$ as pale yellow crystals: mp $123-124{ }^{\circ} \mathrm{C}$; IR (KBr) $2195,1585,1472,1441,1354,1103,749,713,687 \mathrm{~cm}^{-1} ;{ }^{1} \mathrm{H} \delta$ 7.91-7.83 (6 H, m), 7.62-7.29 (15 $\mathrm{H}, \mathrm{m}), 6.88(1 \mathrm{H}, \mathrm{td}, J=7.7$ and $1.8 \mathrm{~Hz}), 6.63(1 \mathrm{H}, \mathrm{t}, J=7.3 \mathrm{~Hz}), 6.50(1 \mathrm{H}, \mathrm{d}, J=8.1 \mathrm{~Hz}) ;{ }^{13} \mathrm{C}$ $\delta 152.93,132.90,132.70(\mathrm{~d}, J=9.8 \mathrm{~Hz}), 131.63(\mathrm{~d}, J=2.6 \mathrm{~Hz}), 131.42,131.19(\mathrm{~d}, J=100.5$ Hz), 128.59, 128.51 (d, $J=11.9 \mathrm{~Hz}), 128.11,127.20,125.00,121.41$ (d, $J=9.3 \mathrm{~Hz}), 118.53(\mathrm{~d}, J$ $=22.3 \mathrm{~Hz}), 117.11,91.91,91.45$. Anal. Calcd for $\mathrm{C}_{32} \mathrm{H}_{24} \mathrm{NP}: \mathrm{C}, 84.75 ; \mathrm{H}, 5.33 ; \mathrm{N}, 3.09$. Found: C, 84.93; H, 5.36; N, 3.05.

2-(1-Propynyl)- $N$-(triphenylphosphoranylidene)benzenamine (103f). To $4.220 \mathrm{~g}$ of $\mathrm{Ph}_{3} \mathrm{PBr}_{2}$ (10.0 mmol) were added $1.310 \mathrm{~g}$ of $\mathbf{1 0 2 f}(10.0 \mathrm{mmol}), 2.78 \mathrm{~mL}$ of anhydrous triethylamine, and $100 \mathrm{~mL}$ of anhydrous benzene under a nitrogen atmosphere. The reaction mixture was heated under reflux for $4 \mathrm{~h}$. The white triethylammonium bromide precipitate was removed by 
filtration, and the filtrate was concentrated. The residue was purified by column chromatography (silica gel/40-60\% diethyl ether in hexanes) to furnish $2.776 \mathrm{~g}(7.10 \mathrm{mmol}, 71 \%)$ of $\mathbf{1 0 3 f}$ as colorless crystals: IR (KBr) 3088, 1605, $734 \mathrm{~cm}^{-1} ;{ }^{1} \mathrm{H} \delta$ 7.9-7.77 (6 H, m), 7.6-7.4 (9 H, m), 7.30 $(1 \mathrm{H}, \mathrm{dt}, J=7.4$ and $2.0 \mathrm{~Hz}), 6.82(1 \mathrm{H}, \mathrm{td}, J=7.7$ and $1.6 \mathrm{~Hz}), 6.58(1 \mathrm{H}, \mathrm{t}, J=7.4 \mathrm{~Hz}), 6.49(1$ $\mathrm{H}, \mathrm{d}, J=8.2 \mathrm{~Hz}), 2.16(3 \mathrm{H}, \mathrm{s}),{ }^{13} \mathrm{C} \delta 152.48,132.68(\mathrm{~d}, J=9.8 \mathrm{~Hz}), 132.65,131.54(\mathrm{~d}, J=2.6$ $\mathrm{Hz}), 131.38(\mathrm{~d}, J=100.5 \mathrm{~Hz}), 128.43(\mathrm{~d}, J=11.9 \mathrm{~Hz}), 127.68,121.58(\mathrm{~d}, J=9.3 \mathrm{~Hz}), 119.32(\mathrm{~d}$, $J=21.2 \mathrm{~Hz}), 117.08,87.70,80.76,4.95$.

Ketenimine 104b. To a solution of $0.433 \mathrm{~g}$ of $\mathbf{1 0 3 b}(1.00 \mathrm{mmol})$ in $30 \mathrm{~mL}$ of anhydrous diethyl ether was introduced $0.194 \mathrm{~g}$ of diphenylketene $(1.00 \mathrm{mmol})$ in $5 \mathrm{~mL}$ of anhydrous diethyl ether via cannula at $0{ }^{\circ} \mathrm{C}$ under a nitrogen atmosphere. The reaction mixture was stirred for $10 \mathrm{~min}$ before it was allowed to warm to room temperature. After one hour, the reaction mixture was concentrated in vacuo. The residue was purified by column chromatography (silica gel $/ 5-10 \%$ diethyl ether in hexanes) to furnish $0.248 \mathrm{~g}(0.71 \mathrm{mmol}, 71 \%)$ of $\mathbf{1 0 4 b}$ as a yellow oil: IR (neat) 2000, 1594, 1491, 758, $693 \mathrm{~cm}^{-1} ;{ }^{1} \mathrm{H} \delta$ 7.49-7.16 (14 H, m), $1.25(9 \mathrm{H}, \mathrm{s}) ;{ }^{13} \mathrm{C} \delta$ 188.80, 141.29, $134.16,133.73,128.74,128.42,127.89,126.91,126.21,123.43,119.68,105.25,76.47,75.70$ 30.78, 28.19; MS $m / z 349\left(\mathrm{M}^{+}\right)$.

Ketenimine 104c. The same procedure was repeated as described for $104 \mathrm{~b}$ except that $0.449 \mathrm{~g}$ of $103 \mathrm{c}(1.00 \mathrm{mmol})$ in $20 \mathrm{~mL}$ of anhydrous diethyl ether was treated with $0.194 \mathrm{~g}$ of diphenylketene $(1.00 \mathrm{mmol})$ in $20 \mathrm{~mL}$ of anhydrous diethyl ether to afford $0.271 \mathrm{~g}(0.74 \mathrm{mmol}$, $74 \%$ ) of 104c as a yellow oil: IR (neat) $2154,1997,1248,865,840,759 \mathrm{~cm}^{-1} ;{ }^{1} \mathrm{H} \delta 7.59(1 \mathrm{H}, \mathrm{d}$, $J=7.2 \mathrm{~Hz}), 7.47-7.21(13 \mathrm{H}, \mathrm{m}), 0.25(9 \mathrm{H}, \mathrm{s}) ;{ }^{13} \mathrm{C} \delta 189.81,142.08,134.11,133.95,129.50$, $128.78,127.97,126.93,126.36,123.20,118.81,101.26,101.10,76.96,-0.13 ; \mathrm{MS} m / z 365\left(\mathrm{M}^{+}\right)$. 
Ketenimine 104d. The same procedure was repeated as described for $\mathbf{1 0 4 b}$ except that $0.419 \mathrm{~g}$ of 103d (1.00 mmol) in $20 \mathrm{~mL}$ of anhydrous diethyl ether was treated with $0.194 \mathrm{~g}$ of diphenylketene $(1.00 \mathrm{mmol})$ in $20 \mathrm{~mL}$ of anhydrous diethyl ether and $0.38 \mathrm{~mL}$ of $1,4-\mathrm{CHD}$ to afford $0.302 \mathrm{~g}(0.90 \mathrm{mmol}, 90 \%)$ of $\mathbf{1 0 4 d}$ as a yellow oil: IR (neat) 2004, 1453, 750, $699 \mathrm{~cm}^{-1}$; ${ }^{1} \mathrm{H} \delta$ 7.49-7.16 (14 H, m), $2.10(2 \mathrm{H}, \mathrm{t}, J=7.2 \mathrm{~Hz}), 1.47(2 \mathrm{H}$, sextet, $J=7.3 \mathrm{~Hz}), 0.94(3 \mathrm{H}, \mathrm{t}, J$ $=7.4 \mathrm{~Hz}) ;{ }^{13} \mathrm{C} \delta 189.41,141.44,134.34,133.65,128.71,128.42,128.00,126.94,126.20$, $123.75,119.61,97.30,76.78,22.02,21.45,13.51$.

2-(Diphenylmethyl)quinoline (106a). To $0.189 \mathrm{~g}$ of $\mathbf{1 0 3 a}(0.50 \mathrm{mmol})$ was added a mixture of $0.097 \mathrm{~g}$ of diphenylketene $(0.50 \mathrm{mmol})$ and $2.9 \mathrm{~mL}$ of $1,4-\mathrm{CHD}$ in $4 \mathrm{~mL}$ of anhydrous benzene via cannula at $0{ }^{\circ} \mathrm{C}$ under a nitrogen atmosphere. After $10 \mathrm{~min}$, the reaction mixture was allowed to warm to room temperature for one hour and then was heated under reflux for 2 hours. The reaction mixture was concentrated in vacuo, and the residue was purified by column chromatography (silica gel/5-20\% of diethyl ether in hexanes). The eluent was allowed to evaporate slowly to furnish $0.072 \mathrm{~g}$ of $\mathbf{1 0 6 a}(0.244 \mathrm{mmol}, 49 \%)$ as yellow crystals.

The rate of reaction was determined by using a solution obtained from treatment of 0.189 $\mathrm{g}$ of 103a $(0.50 \mathrm{mmol})$ with a solution of $0.097 \mathrm{~g}$ of diphenylketene $(0.50 \mathrm{mmol})$ in $2.0 \mathrm{~mL}$ of $\mathrm{C}_{6} \mathrm{D}_{6}$ and $1.5 \mathrm{~mL}$ of $1,4-\mathrm{CHD}$ at $22{ }^{\circ} \mathrm{C}$. The rate of disappearance of 104a and appearance 106a was monitored with IR (cell thickness $=0.11 \mathrm{~mm}$ ) and ${ }^{1} \mathrm{H}$ NMR.

Preparation of 106a by the dehydration method was carried out in a $100-\mathrm{mL}$ flask containing $0.400 \mathrm{~g}$ of 112a $(1.29 \mathrm{mmol}), 2 \mathrm{~g}$ of Florisil, $1.10 \mathrm{~g}$ of $\mathrm{P}_{2} \mathrm{O}_{5}(7.72 \mathrm{mmol}), 30 \mathrm{~mL}$ of pyridine, and $1.66 \mathrm{~mL}$ of $\gamma$-terpinene $(10.3 \mathrm{mmol})$, and the reaction flask was flushed with nitrogen. The mixture was stirred vigorously and heated under reflux (oil bath temperature 135 ${ }^{\circ} \mathrm{C}$ ) for 16 hours before it was allowed to cool to room temperature. The liquid phase was 
filtered through a short Florisil column using dry pyridine as eluent. The residue in the flask was extracted with dry pyridine $(3 \times 15 \mathrm{~mL})$, and the combined pyridine extracts were passed through the same Florisil column. The combined pyridine solutions were concentrated in vacuo. The residue was purified by column chromatography (silica gel/5-20\% of diethyl ether in hexanes). The eluent was allowed to evaporate slowly to furnish $0.128 \mathrm{~g}$ of $\mathbf{1 0 6 a}(0.434 \mathrm{mmol}, 34 \%)$ as yellow crystals: $\mathrm{mp} 104-105^{\circ} \mathrm{C}$; IR $(\mathrm{KBr}) 1594,1495,824,756,719,698 \mathrm{~cm}^{-1} ;{ }^{1} \mathrm{H} \delta 8.09(1 \mathrm{H}$, $\mathrm{d}, J=8.3 \mathrm{~Hz}), 8.07(1 \mathrm{H}, \mathrm{d}, J=8.3 \mathrm{~Hz}), 7.79(1 \mathrm{H}, \mathrm{dd}, J=8.2$ and $1.1 \mathrm{~Hz}), 7.70(1 \mathrm{H}, \mathrm{tm}, J=7.7$

and 1.6 Hz), $7.51(1 \mathrm{H}, \mathrm{tm}, J=7.5$ and $1.1 \mathrm{~Hz}), 7.35-7.20(11 \mathrm{H}, \mathrm{m}), 5.94(1 \mathrm{H}, \mathrm{s}) ;{ }^{13} \mathrm{C} \delta 163.07$, $147.85,142.59$ (2 carbons), 136.29, 129.41, 129.34, 128.40, 127.44, 126.78, 126.55, 126.20, 121.91, 60.08; MS m/z $295\left(\mathrm{M}^{+}\right), 294,218,217,216,165$. Anal. Calcd for $\mathrm{C}_{22} \mathrm{H}_{17} \mathrm{~N}: \mathrm{C}, 89.46 ; \mathrm{H}$, 5.80; N, 4.74. Found: C, 89.26; H, 5.79; N, 4.73.

\section{2-(Diphenylmethyl)-3-propylquinoline (106d) and 6-Phenyl-11-propyl-5H-} benzo[b]carbazole (109d). A solution of $0.268 \mathrm{~g}$ of $\mathbf{1 0 4 d}(0.80 \mathrm{mmol})$ in $3.0 \mathrm{~mL}$ of $1,4-\mathrm{CHD}$ (31.8 mmol) was heated under reflux for 24 hours. The solution was concentrated in vacuo, and the residue was purified by column chromatography (silica gel/5-20\% diethyl ether in hexanes). The eluent was allowed to evaporate slowly to furnish $0.155 \mathrm{~g}$ of $\mathbf{1 0 6 d}(0.46 \mathrm{mmol}, 58 \%)$ and $0.087 \mathrm{~g}$ of $109 \mathrm{~d}(0.26 \mathrm{mmol}, 33 \%)$ as pale yellow crystals. The rate of reaction was determined by conducting the reaction in $\mathrm{C}_{6} \mathrm{D}_{6}$ containing a large excess of 1,4-CHD and using ${ }^{1} \mathrm{H}$ NMR to monitor the disappearance of $104 \mathrm{~d}$ and the appearance of $106 \mathrm{~d}$ and $109 \mathrm{~d}$ at $52{ }^{\circ} \mathrm{C}$.

Preparation of 106d and 109d by the dehydration method was carried out by using the same procedure described for 106a except that a mixture of $0.706 \mathrm{~g}$ of $\mathbf{1 1 2 d}(2.00 \mathrm{mmol}), 3.5 \mathrm{~g}$ of Florisil, $1.70 \mathrm{~g}$ of $\mathrm{P}_{2} \mathrm{O}_{5}(12.0 \mathrm{mmol}), 50 \mathrm{~mL}$ of pyridine, and $0.76 \mathrm{~mL}$ of 1,4-CHD (8.0 mmol) was used. The reaction mixture was heated under vigorous reflux for 18 hours. Purification by 
column chromatography followed by recrystallization furnished $0.236 \mathrm{~g}$ of $\mathbf{1 0 6} \mathbf{d}(0.700 \mathrm{mmol}$, $35 \%)$ and $0.208 \mathrm{~g}$ of $109 \mathrm{~d}(0.621 \mathrm{mmol}, 31 \%)$ as pale yellow crystals. $106 \mathrm{~d}$ : $\mathrm{mp} 99-100{ }^{\circ} \mathrm{C}$; IR $(\mathrm{KBr}) 1598,1560,753,697 \mathrm{~cm}^{-1} ;{ }^{1} \mathrm{H} \delta 8.03(1 \mathrm{H}, \mathrm{d}, J=8.1 \mathrm{~Hz}), 7.91(1 \mathrm{H}, \mathrm{s}), 7.76(1 \mathrm{H}, \mathrm{d}, J=$ $8.1 \mathrm{~Hz}), 7.62(1 \mathrm{H}, \mathrm{tm}, J=7.7 \mathrm{and} 1.4 \mathrm{~Hz}), 7.48(1 \mathrm{H}, \mathrm{tm}, J=7.5$ and $1.3 \mathrm{~Hz}), 7.39-7.22(10 \mathrm{H}$, m), $6.03(1 \mathrm{H}, \mathrm{s}), 2.85(2 \mathrm{H}, \mathrm{t}, J=7.7 \mathrm{~Hz}), 1.74(2 \mathrm{H}$, sextet, $J=7.6 \mathrm{~Hz}), 1.05(3 \mathrm{H}, \mathrm{t}, J=7.3$ $\mathrm{Hz}) ;{ }^{13} \mathrm{C} \delta 161.46,146.41,142.95$ (2 carbons), 135.38, 134.28, 129.68, 129.48, 128.07, 127.08, 126.66, 126.25, 125.95, 54.85, 34.63, 23.78, 14.13; MS m/z $337\left(\mathrm{M}^{+}\right), 336,322,309,308,307$, 306, 294, 260, 246. Anal. Calcd for $\mathrm{C}_{25} \mathrm{H}_{23} \mathrm{~N}$ : C, 88.98; H, 6.87; N, 4.15. Found: C, 88.78; H, 6.82; N, 4.09. 109d: $\mathrm{mp} 124-125^{\circ} \mathrm{C}$; IR (KBr) $3402,756,700 \mathrm{~cm}^{-1} ;{ }^{1} \mathrm{H} \delta 8.38(1 \mathrm{H}, \mathrm{d}, J=9.1$ Hz), $8.28(1 \mathrm{H}, \mathrm{d}, J=7.9 \mathrm{~Hz}), 7.83(1 \mathrm{H}, \mathrm{d}, J=8.7 \mathrm{~Hz}), 7.82(1 \mathrm{H}, \mathrm{br} \mathrm{s}, \mathrm{NH}), 7.66-7.29(10 \mathrm{H}$, m), $3.75(2 \mathrm{H}, \mathrm{t}, J=8.1 \mathrm{~Hz}), 2.02(2 \mathrm{H}$, sextet, $J=7.7 \mathrm{~Hz}), 1.30(3 \mathrm{H}, \mathrm{t}, J=7.3 \mathrm{~Hz}) ;{ }^{13} \mathrm{C} \delta$ $141.99,137.39,137.05,133.87,130.99,130.83,129.22,127.70,126.88,126.67,125.00,124.81$, $124.15,123.61,122.61,122.39,119.44,116.29,110.05,31.37,23.18,14.80 ; \mathrm{MS} m / z 335\left(\mathrm{M}^{+}\right)$, 306, 291, 146.

6-Phenyl-5H-benzo[ $b]$ carbazole (109a). Preparation of $109 a$ by the dehydration method was carried out by using the same procedure described for 106a except that a mixture of $0.766 \mathrm{~g}$ of $112 \mathrm{c}(2.00 \mathrm{mmol}), 4 \mathrm{~g}$ of Florisil, $1.70 \mathrm{~g}$ of $\mathrm{P}_{2} \mathrm{O}_{5}(12.0 \mathrm{mmol}), 50 \mathrm{~mL}$ of pyridine, and $0.80 \mathrm{~mL}$ of 1,4-CHD (8.5 mmol) was used. A mixture of 109c and 109a was isolated by column chromatography (silica gel/5-20\% diethyl ether in hexanes). Treatment of the mixture of 109c and 109a in $5 \mathrm{~mL}$ of dichloromethane with $3.0 \mathrm{~mL}$ of $1 \mathrm{~N} \mathrm{HCl}$ at $40{ }^{\circ} \mathrm{C}$ for one hour converted all of $109 \mathrm{c}$ to the corresponding desilylated adduct 109a. Purification by column chromatography (silica gel/20\% diethyl ether in hexanes) followed by recrystallization from $10 \%$ of diethyl ether in hexanes furnished $0.475 \mathrm{~g}$ of $109 \mathrm{a}(1.62 \mathrm{mmol}, 81 \%)$ as pale yellow crystals: 
IR (KBr) 3400, 751, $693 \quad \mathrm{~cm}^{-1} ;{ }^{1} \mathrm{H} \delta 8.60(1 \mathrm{H}, \mathrm{s}), 8.24(1 \mathrm{H}, \mathrm{d}, J=7.7 \mathrm{~Hz}), 8.15-8.10(1 \mathrm{H}, \mathrm{m})$, 7.87-7.84 (1 H, m), $7.82(1 \mathrm{H}$, br s, NH), 7.68-7.52 (5 H, m), 7.50-7.41 (3 H, m), 7.34-7.25 (2 H, $\mathrm{m}) ;{ }^{13} \mathrm{C} \delta 141.84,137.64,136.76,130.74,130.64,129.22,128.75,128.61,127.81,127.34$, 125.16, 124.96, 124.44, 123.35, 122.63, 121.15, 119.44, 118.32, 118.10, 110.22; MS m/z 293 $\left(\mathrm{M}^{+}\right), 146$.

6-Phenyl-11-tert-butyl-5H-benzo[b]carbazole (109b). A solution of $0.150 \mathrm{~g}$ of $\mathbf{1 0 4 b}(0.43$ $\mathrm{mmol}$ ) in $3 \mathrm{~mL}$ of anhydrous benzene was heated under reflux for 24 hours. Benzene was allowed to evaporate slowly to afford $0.147 \mathrm{~g}$ of $\mathbf{1 0 9 b}(0.42 \mathrm{mmol}, 98 \%)$ as yellow crystals: $\mathrm{mp}$ 132-133 ${ }^{\circ} \mathrm{C}$; IR (KBr) 3410, 1601, 1462, 747, $699 \mathrm{~cm}^{-1} ;{ }^{1} \mathrm{H} \delta 8.81(1 \mathrm{H}, \mathrm{dd}, J=8.0$ and $2.2 \mathrm{~Hz})$, $8.43(1 \mathrm{H}, \mathrm{d}, J=8.1 \mathrm{~Hz}), 7.78(1 \mathrm{H}, \mathrm{br}, \mathrm{NH}), 7.75-7.71(1 \mathrm{H}, \mathrm{m}), 7.67-7.54(5 \mathrm{H}, \mathrm{m})$, 7.44-7.20 (5 H, m), $2.06(9 \mathrm{H}, \mathrm{s}) ;{ }^{13} \mathrm{C} \delta 143.17,141.79,138.44,137.08,131.46,131.00,129.27,128.68$, $127.77,127.32,127.07,126.33,124.60,124.12,124.06,123.66,120.07,118.31,116.93,109.93$, 38.55, 33.63; MS m/z $349\left(\mathrm{M}^{+}\right), 334,293,241,146,57$; HRMS calcd for $\mathrm{C}_{26} \mathrm{H}_{23} \mathrm{~N}$ 349.1831, found 349.1827. The rate of reaction was determined by conducting the reaction in $\mathrm{C}_{6} \mathrm{D}_{6}$ and using ${ }^{1} \mathrm{H}$ NMR to monitor the disappearance of $104 \mathbf{b}$ and the appearance of $109 \mathbf{b}$ at $72{ }^{\circ} \mathrm{C}$.

6-Phenyl-11-(trimethylsilyl)-5H-benzo[b]carbazole (109c). A mixture of $0.183 \mathrm{~g}$ of $\mathbf{1 0 4 c}$ $(0.50 \mathrm{mmol})$ in $3 \mathrm{~mL}$ of anhydrous benzene was heated under reflux for 24 hours. The reaction mixture was then concentrated in vacuo, and the residue was purified by column chromatography (silica gel $/ 5-20 \%$ diethyl ether in hexanes). The eluent was allowed to evaporate slowly to afford $0.163 \mathrm{~g}$ of $109 \mathrm{c}(0.447 \mathrm{mmol}, 89 \%)$ as pale yellow crystals: $\mathrm{mp} 153-154{ }^{\circ} \mathrm{C}$; IR (KBr) 3403 , $1260,847,769,748,702 \mathrm{~cm}^{-1} ;{ }^{1} \mathrm{H} \delta 8.60-8.53(1 \mathrm{H}, \mathrm{m}), 8.33(1 \mathrm{H}, \mathrm{d}, J=7.9 \mathrm{~Hz}), 7.83(1 \mathrm{H}, \mathrm{br} \mathrm{s}$, NH), 7.82-7.77 (1 H, m), 7.67-7.52 (5 H, m), 7.47-7.36 (3 H, m), 7.32 (1 H, d, J= 7.9 Hz), 7.23 $(1 \mathrm{H}, \mathrm{tm}, J=7.9$ and $1.1 \mathrm{~Hz}), 0.78(9 \mathrm{H}, \mathrm{s}) ;{ }^{13} \mathrm{C} \delta 142.27,137.01,136.82,133.31,132.29$. 
$131.40,130.77,130.20,129.53,129.27,127.92,126.92,126.53,124.89,124.53,123.81,121.67$, 119.73, 118.33, 110.06, 3.47; MS m/z $365\left(\mathrm{M}^{+}\right)$, 350. Anal. Calcd for $\mathrm{C}_{25} \mathrm{H}_{23} \mathrm{NSi}$ C, 82.14; $\mathrm{H}$, 6.34; N, 3.83. Found: $\mathrm{C}, 82.26 ; \mathrm{H}, 6.42 ; \mathrm{N}, 3.80$. The rate of reaction was determined by conducting the reaction in $\mathrm{C}_{6} \mathrm{D}_{6}$ and using ${ }^{1} \mathrm{H}$ NMR to monitor the disappearance of $\mathbf{1 0 4 c}$ and the appearance of $109 \mathrm{c}$ at $72{ }^{\circ} \mathrm{C}$.

6,11-Diphenyl-5H-benzo[b]carbazole (109e). To a solution of $0.453 \mathrm{~g}$ of $103 \mathrm{e}(1.00 \mathrm{mmol})$ in $30 \mathrm{~mL}$ of anhydrous diethyl ether was introduced $0.194 \mathrm{~g}$ of diphenylketene $(1.00 \mathrm{mmol})$ in 5 $\mathrm{mL}$ of anhydrous diethyl ether at $0{ }^{\circ} \mathrm{C}$. The reaction mixture was allowed to warm to room temperature and was stirred for one hour. At this point, the benzocarbazole 109e had already formed. The reaction mixture was concentrated in vacuo, and the residue was purified by column chromatography (silica gel/5-20\% diethyl ether in hexanes). The eluent was allowed to evaporate slowly to afford $0.343 \mathrm{~g}$ of $\mathbf{1 0 9 e}(0.93 \mathrm{mmol}, 93 \%)$ as pale yellow crystals.

Preparation of 109e by the dehydration method was carried out by using the same procedure described for 106a except that a mixture of $0.724 \mathrm{~g}$ of $112 \mathrm{e}(1.87 \mathrm{mmol}), 3 \mathrm{~g}$ of Florisil, $1.59 \mathrm{~g}$ of $\mathrm{P}_{2} \mathrm{O}_{5}(11.2 \mathrm{mmol}), 40 \mathrm{~mL}$ of pyridine, and $0.71 \mathrm{~mL}$ of 1,4-CHD (7.5 mmol) was used. Purification by column chromatography afforded $0.483 \mathrm{~g}$ of $\mathbf{1 0 9 e}(1.31 \mathrm{mmol}, 70 \%)$ as pale yellow crystals: $\mathrm{mp} 241-242{ }^{\circ} \mathrm{C}$; IR $(\mathrm{KBr}) 3451,754,702 \mathrm{~cm}^{-1} ;{ }^{1} \mathrm{H} \delta 7.88(1 \mathrm{H}, \mathrm{d}, J=8.7$ Hz), $7.85(1 \mathrm{H}$, br s, NH), $7.80(1 \mathrm{H}, \mathrm{d}, J=8.5 \mathrm{~Hz}), 7.70-7.53(10 \mathrm{H}, \mathrm{m}), 7.42(1 \mathrm{H}, \mathrm{tm}, J=7.5$ and 1.3 Hz), 7.37-7.27 (3 H, m), 6.92-6.90 (2 H, m); ${ }^{13} \mathrm{C} \delta 141.99,139.06,137.11,136.83$, $133.42,130.89,130.53,130.23,129.29,128.95,127.86,127.81,127.65,126.99,126.56,125.01$, 124.41, 123.45, 123.20, 122.94, 122.50, 119.14, 117.57, 109.87; MS m/z $369\left(\mathrm{M}^{+}\right), 291,183$, 146. Anal. Calcd for $\mathrm{C}_{28} \mathrm{H}_{19} \mathrm{~N}$ : C, 91.03; H, 5.18; N, 3.79. Found: C, 90.75; H, 5.27; N, 3.71. 
$N$-(2-Ethynylphenyl)diphenylacetamide (112a). To $0.351 \mathrm{~g}$ of 2-ethynylaniline (102a, 3.00 mmol) in a $50-\mathrm{mL}$ flask were added $0.762 \mathrm{~g}$ of diphenylacetyl chloride $(3.30 \mathrm{mmol}), 5 \mathrm{~mL}$ of anhydrous diethyl ether, and $0.8 \mathrm{~mL}$ of anhydrous triethylamine under a nitrogen atmosphere. The reaction mixture was heated under reflux for 2 hours and then was concentrated in vacuo. The residue was purified by column chromatography (silica gel/10-20\% diethyl ether in hexanes) to furnish $0.803 \mathrm{~g}(2.58 \mathrm{mmol}, 86 \%)$ of 112a as yellow crystalline needles: IR (KBr) 3290, 3219, 2107, 1665, 755, 701, $656 \mathrm{~cm}^{-1} ;{ }^{1} \mathrm{H} \delta 8.55(1 \mathrm{H}, \mathrm{d}, J=8.1 \mathrm{~Hz}), 8.24(1 \mathrm{H}, \mathrm{br}$ ) $)$ 7.43-7.29 (12 H, m), $7.03(1 \mathrm{H}, \mathrm{td}, J=7.6$ and $1.1 \mathrm{~Hz}), 5.21(1 \mathrm{H}, \mathrm{s}), 3.01(1 \mathrm{H}, \mathrm{s}) ;{ }^{13} \mathrm{C} \delta 170.25,139.45,138.83$, $131.81,130.13,129.19,128.96,127.45,123.48,118.98,110.84,84.18,78.25,60.63 ; \mathrm{MS} \mathrm{m} / \mathrm{z}$ $311\left(\mathrm{M}^{+}\right), 194,168,167,165,152,116$.

$N$-[2-(Trimethylsilylethynyl)phenyl]diphenylacetamide (112c). The same procedure was repeated as described for 112a except that a mixture of $0.756 \mathrm{~g}$ of 2 [(trimethylsilyl)ethynyl]aniline $(\mathbf{1 0 2 c}, 4.00 \mathrm{mmol}), 1.015 \mathrm{~g}$ of diphenylacetyl chloride (4.40 mmol), and $1.1 \mathrm{~mL}$ of triethylamine in $5 \mathrm{~mL}$ of diethyl ether was heated under reflux for 15 hours to afford $1.411 \mathrm{~g}(3.68 \mathrm{mmol}, 92 \%)$ of $\mathbf{1 1 2 c}$ as colorless crystalline needles: IR (KBr) 3370, 2151, 1708, 1251, 842, 745, $698 \mathrm{~cm}^{-1} ;{ }^{1} \mathrm{H} \delta 8.45(1 \mathrm{H}, \mathrm{d}, J=8.5 \mathrm{~Hz}), 8.18$ (1 H, br s), 7.41-7.25 (12 H, m), $7.01(1 \mathrm{H}, \mathrm{td}, J=7.6$ and $1.1 \mathrm{~Hz}), 5.07(1 \mathrm{H}, \mathrm{s}), 0.20(9 \mathrm{H}, \mathrm{s}) ;{ }^{13} \mathrm{C} \delta 170.05$, $139.10,138.64,131.94,129.83,128.86,128.84,127.49,123.40,119.26,111.95,102.00,99.85$, 60.50, -0.09; MS m/z $383\left(\mathrm{M}^{+}\right), 368,216,215,200,168,167,165,152,115,73$.

$N$-[2-(1-Pentynyl)phenyl]diphenylacetamide (112d). The same procedure was repeated as described for 112a except that a mixture of $0.340 \mathrm{~g}$ of 2-(1-pentynyl)aniline (102d, $2.14 \mathrm{mmol})$, $0.544 \mathrm{~g}$ of diphenylacetyl chloride $(2.35 \mathrm{mmol})$, and $0.7 \mathrm{~mL}$ of triethylamine in $5 \mathrm{~mL}$ of diethyl ether was heated under reflux for 15 hours to afford $0.635 \mathrm{~g}(1.80 \mathrm{mmol}, 84 \%)$ of $\mathbf{1 1 2 d}$ as 
colorless crystals: IR (KBr) 3301, 2234, 1663, 743, $701 \mathrm{~cm}^{-1} ;{ }^{1} \mathrm{H} \delta 8.48(1 \mathrm{H}, \mathrm{d}, J=8.3 \mathrm{~Hz}), 8.15$ (1 H, br s), 7.41-7.24 (12 H, m), $7.00(1 \mathrm{H}, \mathrm{td}, J=7.5$ and $1.2 \mathrm{~Hz}), 5.15(1 \mathrm{H}, \mathrm{s}), 2.14(2 \mathrm{H}, \mathrm{t}, J=$ $7.1 \mathrm{~Hz}), 1.47(2 \mathrm{H}$, sextet, $J=7.3 \mathrm{~Hz}), 0.97(3 \mathrm{H}, \mathrm{t}, J=7.4 \mathrm{~Hz}) ;{ }^{13} \mathrm{C} \delta 170.22,138.88,138.61$, $131.67,129.11,128.87,128.78,127.46,123.45,118.96,112.83,97.59,75.38,60.67,22.06$, 21.31, 13.54; MS $m / z 353\left(\mathrm{M}^{+}\right), 325,310,296,186,167,165,152$.

$N$-[2-(Phenylethynyl)phenyl]diphenylacetamide (112e). The same procedure was repeated as described for 112a except that a mixture of $0.386 \mathrm{~g}$ of 2-(phenylethynyl)aniline (102e, 2.00 mmol), $0.461 \mathrm{~g}$ of diphenylacetyl chloride $(2.00 \mathrm{mmol})$, and $0.3 \mathrm{~mL}$ of anhydrous pyridine in 10 $\mathrm{mL}$ of diethyl ether was heated under reflux for four hours to afford $0.724 \mathrm{~g}(1.87 \mathrm{mmol}, 94 \%)$ of 112e as colorless crystals: $\mathrm{IR}(\mathrm{KBr}) 3222,1654,749,702,692 \mathrm{~cm}^{-1} ;{ }^{1} \mathrm{H} \delta 8.51(1 \mathrm{H}, \mathrm{d}, J=8.3$ Hz), $8.20(1 \mathrm{H}, \mathrm{br} \mathrm{s}), 7.45(1 \mathrm{H}, \mathrm{dd}, J=7.7$ and $1.4 \mathrm{~Hz}), 7.39-7.22(14 \mathrm{H}, \mathrm{m}), 7.16(2 \mathrm{H}, \mathrm{tt}, J=$ 7.1 and 1.6 Hz), $7.07(1 \mathrm{H}, \mathrm{td}, J=7.6$ and $1.2 \mathrm{~Hz}), 5.17(1 \mathrm{H}, \mathrm{s}) ;{ }^{13} \mathrm{C} \delta 170.27,138.73,138.68$, $131.81,131.72,129.67,128.94,128.91,128.81,128.25,127.50,123.66,122.13,119.42,112.19$, 96.08, 83.62, 60.64; MS m/z $387\left(\mathrm{M}^{+}\right), 310,296,220,219,193,167,165,152$. $N$-[2-(phenylethynyl)phenyl]phenylacetamide (113). The same procedure was repeated as described for 112a except that a mixture of $0.965 \mathrm{~g}$ of 2-(phenylethynyl)aniline (102e, 5.00 mmol), $0.70 \mathrm{~mL}$ of phenylacetyl chloride $(0.82 \mathrm{~g}, 5.3 \mathrm{mmol})$, and $1.4 \mathrm{~mL}$ of triethylamine in 20 $\mathrm{mL}$ of diethyl ether was stirred at room temperature for three hours to afford $1.512 \mathrm{~g}(4.86 \mathrm{mmol}$, 97\%) of $\mathbf{1 1 3}$ as colorless crystals: $\mathrm{IR}(\mathrm{KBr}) 3300,1664,756,688 \mathrm{~cm}^{-1} ;{ }^{1} \mathrm{H} \delta 8.45(1 \mathrm{H}, \mathrm{d}, J=8.3$ Hz), 7.96 (1 H, br s), 7.44-7.29 (9 H, m), 7.15 (2 H, tm, $J=7.2$ and 1.0 Hz), 7.09-7.01 (2 H, m), $3.80(2 \mathrm{H}, \mathrm{s}) ;{ }^{13} \mathrm{C} \delta 169.21,138.67,133.86,131.87,131.79,129.64,129.50,129.18,128.85$, $128.28,127.65,123.52,122.19,119.29,112.00,95.92,83.60,45.39 ; \mathrm{MS} m / z 311\left(\mathrm{M}^{+}\right), 220$ 193, 165, 91. 
11-Phenyl-5H-benzo[b]carbazole (114). The same dehydration procedure was repeated as described for 106a except that a mixture of $0.622 \mathrm{~g}$ of $113(2.00 \mathrm{mmol}), 3 \mathrm{~g}$ of Florisil, $1.42 \mathrm{~g}$ of $\mathrm{P}_{2} \mathrm{O}_{5}(10.0 \mathrm{mmol}), 30 \mathrm{~mL}$ of triethylamine, and $0.57 \mathrm{~mL}$ of $1,4-\mathrm{CHD}(6.0 \mathrm{mmol})$ was used. The reaction mixture was heated under reflux for 40 hours. Purification by column chromatography followed by recrystallization afforded $0.157 \mathrm{~g}$ of $114(0.54 \mathrm{mmol}, 27 \%)$ as pale yellow crystals: IR (KBr) 3408, 748, $704 \mathrm{~cm}^{-1} ;{ }^{1} \mathrm{H} \delta 8.00(1 \mathrm{H}, \mathrm{br} \mathrm{s}, \mathrm{NH}), 7.97(1 \mathrm{H}, \mathrm{d}, J=8.3 \mathrm{~Hz}), 7.79(1 \mathrm{H}, \mathrm{s})$, $7.73(1 \mathrm{H}, \mathrm{d}, J=8.5 \mathrm{~Hz}), 7.68-7.60(3 \mathrm{H}, \mathrm{m}), 7.55-7.45(3 \mathrm{H}, \mathrm{m}), 7.39-7.36(2 \mathrm{H}, \mathrm{m}), 7.31(1 \mathrm{H}$, tm, $J=7.6$ and $1.2 \mathrm{~Hz}$ ), 6.96-6.87 (2 H, m); ${ }^{13} \mathrm{C} \delta 142.15,138.92$ (2 carbons), 133.87, 132.55, $130.13,128.90,127.78,127.51,126.97,126.90,126.34,125.00,123.60,123.29,123.11,122.68$ 119.15, 109.87, 104.73; MS m/z $293\left(\mathrm{M}^{+}\right), 146$.

$N$-(2-Ethynylphenyl)- $N$ '-phenylcarbodiimide (126a). ${ }^{25 b}$ The following procedure for the preparation of 126a is representative. To $0.377 \mathrm{~g}$ of $\mathbf{1 0 3 a}(1.00 \mathrm{mmol})$ was introduced a solution of $0.119 \mathrm{~g}$ of phenyl isocyanate $(1.00 \mathrm{mmol})$ in $15 \mathrm{~mL}$ of anhydrous benzene via cannula under a nitrogen atmosphere at $\mathrm{rt}$. After $1 \mathrm{~h}$, the reaction mixture was concentrated in vacuo, and the residue was purified by column chromatography (silica gel $/ 5 \%$ diethyl ether in hexanes) to furnish $0.181 \mathrm{~g}(0.83 \mathrm{mmol}, 83 \%)$ of $\mathbf{1 2 6 a}$ as a yellow oil: IR (neat) 3285, 2258, 2139, 2103, $1592,754,689 \mathrm{~cm}^{-1} ;{ }^{1} \mathrm{H} \delta 7.49(1 \mathrm{H}, \mathrm{dd}, J=7.6$ and $1.4 \mathrm{~Hz}), 7.37-7.28(3 \mathrm{H}, \mathrm{m}), 7.25-7.10(5 \mathrm{H}$, m), $3.26(1 \mathrm{H}, \mathrm{s}) ;{ }^{13} \mathrm{C} \delta 140.58,138.34,133.60,129.90,129.37,125.50,125.14,124.47,124.40$, 118.30, 83.88, 80.19; MS m/z $218\left(\mathrm{M}^{+}\right), 190,114,89,77$; HRMS calcd for $\mathrm{C}_{15} \mathrm{H}_{10} \mathrm{~N}_{2} 218.0844$, found 218.0837 .

$N$-[2-(3,3-Dimethyl-1-butynyl)phenyl]- $N$ '-phenylcarbodiimide (126b). The same procedure was repeated as described for $\mathbf{1 2 6} \mathbf{a}$ except that $0.866 \mathrm{~g}$ of $\mathbf{1 0 3 b}(2.00 \mathrm{mmol})$ was treated with $0.238 \mathrm{~g}$ of phenyl isocyanate $(2.00 \mathrm{mmol})$ in $20 \mathrm{~mL}$ of anhydrous benzene to afford $0.449 \mathrm{~g}$ 
(1.64 mmol, 82\%) of $\mathbf{1 2 6 b}$ as a pale yellow oil: IR (neat) $2244,2141,2106,1590,755 \mathrm{~cm}^{-1} ;{ }^{1} \mathrm{H} \delta$ $7.42(1 \mathrm{H}, \mathrm{dd}, J=7.9$ and $1.6 \mathrm{~Hz}), 7.38-7.07(8 \mathrm{H}, \mathrm{m}), 1.21(9 \mathrm{H}, \mathrm{s}) ;{ }^{13} \mathrm{C} \delta 139.37,137.95$, $133.49,129.39,128.37,125.21,125.09,124.56,124.28,120.89,106.34,75.30,30.49,28.18$; MS $m / z 274\left(\mathrm{M}^{+}\right), 273,259,243,218$; HRMS calcd for $\mathrm{C}_{19} \mathrm{H}_{17} \mathrm{~N}_{2}\left(\mathrm{M}^{+}-1\right)$ 273.1392, found 273.1381. $N$-[2-(Trimethylsilylethynyl)phenyl]- $N$ '-phenylcarbodiimide (126c). The same procedure was repeated as described for $126 \mathrm{a}$ except that $0.746 \mathrm{~g}$ of $\mathbf{1 0 3 c}(1.66 \mathrm{mmol})$ was treated with $0.198 \mathrm{~g}$ of phenyl isocyanate $(1.66 \mathrm{mmol})$ in $20 \mathrm{~mL}$ of anhydrous benzene to afford $0.339 \mathrm{~g}$ (1.17 mmol, 71\%) of 126c as a yellow oil: IR (neat) 2142, 2107, 1590, 1249, 864, 843, 755, 689 $\mathrm{cm}^{-1} ;{ }^{1} \mathrm{H} \delta 7.47(1 \mathrm{H}, \mathrm{dd}, J=8.0$ and $1.5 \mathrm{~Hz}), 7.37-7.08(8 \mathrm{H}, \mathrm{m}), 0.08(9 \mathrm{H}, \mathrm{s}) ;{ }^{13} \mathrm{C} \delta 139.02$, $138.90,133.87,129.49,129.44,125.26,125.19,124.61,124.46,119.75,102.48,100.68,-0.48$; MS $m / z 290\left(\mathrm{M}^{+}\right), 289,275,259,245,218,183,73$; HRMS calcd for $\mathrm{C}_{18} \mathrm{H}_{17} \mathrm{~N}_{2} \mathrm{Si}\left(\mathrm{M}^{+}-1\right)$ 289.1161, found 289.1148 .

$N$-[2-(1-Pentynyl)phenyl]- $N$ '-phenylcarbodiimide (126 d). The same procedure was repeated as described for 126a except that $0.871 \mathrm{~g}$ of $\mathbf{1 0 3 d}(2.08 \mathrm{mmol})$ was treated with $0.248 \mathrm{~g}$ of phenyl isocyanate $(2.08 \mathrm{mmol})$ in $30 \mathrm{~mL}$ of anhydrous benzene to afford $0.427 \mathrm{~g}(1.64 \mathrm{mmol}$, $79 \%$ ) of 126d as a yellow oil: IR (neat) 2247, 2143, 2107, 1592, 756, $689 \mathrm{~cm}^{-1} ;{ }^{1} \mathrm{H} \delta 7.44(1 \mathrm{H}$, dd, $J=7.9$ and $1.5 \mathrm{~Hz}), 7.4-7.08(8 \mathrm{H}, \mathrm{m}), 2.10(2 \mathrm{H}, \mathrm{t}, J=7.2 \mathrm{~Hz}), 1.46(2 \mathrm{H}$, sextet, $J=7.3$ $\mathrm{Hz}), 0.93(3 \mathrm{H}, \mathrm{t}, J=7.3 \mathrm{~Hz}) ;{ }^{13} \mathrm{C} \delta 139.16,138.72,133.65,133.01,129.25,128.39,125.12$, $125.05,124.25,124.19,120.78,98.70,76.87,21.69,21.53,13.40 ; \mathrm{MS} \mathrm{m} / z 260\left(\mathrm{M}^{+}\right), 245,231$, 218; HRMS calcd for $\mathrm{C}_{18} \mathrm{H}_{16} \mathrm{~N}_{2} 260.1314$, found 260.1312 .

$N$-[2-(2-Phenylethynyl)phenyl]- $N$ '-phenylcarbodiimide (126e). The same procedure was repeated as described for 126a except that $0.622 \mathrm{~g}$ of $\mathbf{1 0 3 e}(1.37 \mathrm{mmol})$ was treated with $0.164 \mathrm{~g}$ of phenyl isocyanate $(1.37 \mathrm{mmol})$ in $15 \mathrm{~mL}$ of anhydrous benzene to afford $0.286 \mathrm{~g}(0.973$ 
mmol, 71\%) of 126e as a pale yellow oil: IR (neat) 2138, 1590, 754, $689 \mathrm{~cm}^{-1} ;{ }^{1} \mathrm{H} \delta 7.53(1 \mathrm{H}$, $\mathrm{dm}, J=7.7$ and $1.5 \mathrm{~Hz}), 7.37-7.06(13 \mathrm{H}, \mathrm{m}) ;{ }^{13} \mathrm{C} \delta 138.75,138.68,133.25,132.88,131.54$, $129.31,129.27,128.36,128.05,125.27,125.19,124.60,124.31,122.69,119.99,96.22,85.56$; MS $m / z, 294\left(\mathrm{M}^{+}\right), 264,216,190,176,147,77$; HRMS calcd for $\mathrm{C}_{21} \mathrm{H}_{14} \mathrm{~N}_{2} 294.1157$, found 294.1171.

$N$-[2-(1-Propynyl)phenyl]- $N$ '-phenylcarbodiimide (126f). The same procedure was repeated as described for $\mathbf{1 2 6}$ except that $0.782 \mathrm{~g}$ of $\mathbf{1 0 3 f}(2.00 \mathrm{mmol})$ was treated with $0.238 \mathrm{~g}$ of phenyl isocyanate $(2.00 \mathrm{mmol})$ in $20 \mathrm{~mL}$ of anhydrous benzene to afford $0.330 \mathrm{~g}(1.42 \mathrm{mmol}, 71 \%)$ of 126f as a pale yellow oil: IR (neat) $2138,1590,756,686 \mathrm{~cm}^{-1} ;{ }^{1} \mathrm{H}\left(\mathrm{C}_{6} \mathrm{D}_{6}\right) \delta 7.35(1 \mathrm{H}, \mathrm{dd}, J=7.7$ and 1.5 Hz), $7.13(2 \mathrm{H}, \mathrm{m}), 6.99-6.91(3 \mathrm{H}, \mathrm{m}), 6.86-6.77(2 \mathrm{H}, \mathrm{m}), 6.71(1 \mathrm{H}, \mathrm{td}, J=7.5$ and 1.4 $\mathrm{Hz}), 1.39(3 \mathrm{H}, \mathrm{s}) ;{ }^{13} \mathrm{C}\left(\mathrm{C}_{6} \mathrm{D}_{6}\right) \delta 139.93,139.66,134.33,133.10,129.59,128.78,125.42,125.19$, 124.75, 124.64, 121.55, 94.98, 76.75, 4.27; MS m/z $232\left(\mathrm{M}^{+}\right), 231$.

2-(Phenylamino)quinoline (128a) ${ }^{25 b, 49 b}$ and $6 H$-Indolo[2,3-b]quinoline (131a). ${ }^{25 b, 56} \mathrm{~A}$ solution of $0.182 \mathrm{~g}(0.835 \mathrm{mmol})$ of $\mathbf{1 2 6 a}$ in $2.0 \mathrm{~mL}$ of $\gamma$-terpinene was heated under a nitrogen atmosphere at $138^{\circ} \mathrm{C}$ for $14 \mathrm{~h}$. After the reaction mixture was cooled to rt, a pale yellow solid precipitated out of the solution and coated the inside wall of the flask. The $\gamma$-terpinene solution was removed with a pipet, and the remaining solid was washed with benzene and dried in vacuo to give $0.029 \mathrm{~g}(0.13 \mathrm{mmol}, 16 \%)$ of $\mathbf{1 3 1 a}\left(\mathrm{mp} 338-340{ }^{\circ} \mathrm{C}\right.$, lit. $\left.^{25 \mathrm{~b}} 342-346{ }^{\circ} \mathrm{C}\right)$ as a pale yellow solid. The combined solution of benzene and $\gamma$-terpinene was concentrated in vacuo, and the residue was purified by preparative thin layer chromatography (silica gel $/ 40 \%$ diethyl ether in hexanes) to furnish $0.090 \mathrm{~g}(0.41 \mathrm{mmol}, 49 \%)$ of $\mathbf{1 2 8 a}\left(\mathrm{mp} \mathrm{101-103}{ }^{\circ} \mathrm{C}\right.$, lit. $\left.{ }^{49 \mathrm{~b}} 103-104{ }^{\circ} \mathrm{C}\right)$ as a yellow solid. 
The indoloquinoline 131a was also obtained by heating a suspension of $0.076 \mathrm{~g}$ of 131c $(0.26 \mathrm{mmol})$ over $0.5 \mathrm{~mL}$ of a $6 \mathrm{~N}$ sodium hydroxide solution and $0.5 \mathrm{~mL}$ of ethanol under reflux for $12 \mathrm{~h}$. Then, the reaction mixture was cooled to rt, and $0.5 \mathrm{~mL}$ of water was added. The supernatant liquid was removed with a pipette, and the residue was washed with water and dichloromethane to give $0.053 \mathrm{~g}$ of 131a $(0.24 \mathrm{mmol}, 92 \%)$.

11-(1,1-Dimethylethyl)-6H-indolo[2,3-b]quinoline (131b). A solution of $0.289 \mathrm{~g}$ of $\mathbf{1 2 6 b}$ (1.05 mmol) in $3.0 \mathrm{~mL}$ of $p$-xylene was heated under reflux for $14 \mathrm{~h}$. The reaction mixture was then concentrated, and the residue was purified by flash chromatography (silica gel/20-50\% diethyl ether in hexanes) to afford $0.220 \mathrm{~g}(0.803 \mathrm{mmol}, 76 \%)$ of $\mathbf{1 3 1 b}$ as bright yellow crystals: $\mathrm{mp}$ 237-239 ${ }^{\circ} \mathrm{C}$; IR $(\mathrm{KBr}) 1590,741 \mathrm{~cm}^{-1} ;{ }^{1} \mathrm{H} \delta 10.9(1 \mathrm{H}, \mathrm{br} \mathrm{s}, \mathrm{NH}), 8.88(1 \mathrm{H}, \mathrm{dd}, J=9.0$ and 0.9 $\mathrm{Hz}), 8.36(1 \mathrm{H}, \mathrm{d}, J=8.2 \mathrm{~Hz}), 8.15(1 \mathrm{H}, \mathrm{d}, J=8.4 \mathrm{~Hz}), 7.71(1 \mathrm{H}, \mathrm{ddd}, J=8.3,6.8$, and $1.2 \mathrm{~Hz})$, 7.55-7.46 (2 H, m), $7.39(1 \mathrm{H}$, ddd, $J=8.9,6.7$, and $1.5 \mathrm{~Hz}), 7.29(1 \mathrm{H}, \mathrm{ddd}, J=8.2,5.9$, and 2.5 $\mathrm{Hz}), 2.04(9 \mathrm{H}, \mathrm{s}) ;{ }^{13} \mathrm{C} \delta 154.23,153.63,147.12,140.99,128.64,128.17,127.25,127.00,123.69$, 121.42, 121.19, 119.28, 117.99, 110.68, 39.12, 32.99; MS m/z $274\left(\mathrm{M}^{+}\right), 259,243,219,190$, 122; HRMS calcd for $\mathrm{C}_{19} \mathrm{H}_{18} \mathrm{~N}_{2} 274.1470$, found 274.1475.

11-(Trimethylsilyl)-6H-indolo[2,3-b]quinoline (131c). A solution of $0.216 \mathrm{~g}$ of $\mathbf{1 2 6 c}(0.745$ $\mathrm{mmol}$ ) in $3.0 \mathrm{~mL}$ of $p$-xylene was heated under reflux for $5 \mathrm{~h}$. The reaction mixture was then concentrated, and the residue was purified by flash chromatography (silica gel $/ 20-50 \%$ diethyl ether in hexanes) to afford $0.186 \mathrm{~g}(0.641 \mathrm{mmol}, 86 \%)$ of $131 \mathrm{c}$ as bright pale yellow crystals: $\mathrm{mp}$ 247-248 ${ }^{\circ} \mathrm{C}$; IR (KBr) 3060, 1252, 864, 842, $743 \mathrm{~cm}^{-1} ;{ }^{1} \mathrm{H} \delta 11.79(1 \mathrm{H}, \mathrm{br} \mathrm{s}, \mathrm{NH}), 8.53(1 \mathrm{H}, \mathrm{d}, J$ $=8.4 \mathrm{~Hz}), 8.26(1 \mathrm{H}, \mathrm{d}, J=7.9 \mathrm{~Hz}), 8.24(1 \mathrm{H}, \mathrm{dd}, J=7.9$ and $1.1 \mathrm{~Hz}), 7.78(1 \mathrm{H}, \mathrm{ddd}, J=8.2$, 6.8, and 1.3 Hz), 7.60-7.46 (3 H, m), $7.28(1 \mathrm{H}$, ddd, $J=8.2,6.9$, and $1.6 \mathrm{~Hz}), 0.80(9 \mathrm{H}, \mathrm{s}) ;{ }^{13} \mathrm{C}$ $\delta 152.14,145.15,144.57,141.81,129.21,128.46,128.38,127.81,127.12,126.44,125.18$, 
122.21, 121.54, 119.17, 110.87, 2.57; MS m/z $290\left(\mathrm{M}^{+}\right), 275,259,245,231,218,73$; HRMS calcd for $\mathrm{C}_{18} \mathrm{H}_{18} \mathrm{~N}_{2} \mathrm{Si} 290.1239$, found 290.1242 .

The indoloquinoline 131c (61\% yield) was also synthesized in a one-pot operation from $\mathbf{1 0 3 c}$ and phenyl isocyanate without isolation of $\mathbf{1 2 6} \mathbf{c}$.

11-Propyl-6H-indolo[2,3-b ]quinoline (131d). A solution of $0.368 \mathrm{~g}$ of $\mathbf{1 2 6 d}(1.42 \mathrm{mmol})$ in $4.0 \mathrm{~mL}$ of $p$-xylene was heated under reflux for $5 \mathrm{~h}$. The reaction mixture was then concentrated, and the residue was purified by flash chromatography (silica gel/20-50\% diethyl ether in hexanes) to afford $0.329 \mathrm{~g}(1.27 \mathrm{mmol}, 89 \%)$ of $\mathbf{1 3 1 d}$ as golden yellow crystals: $\mathrm{mp} 245-246{ }^{\circ} \mathrm{C}$ IR (KBr) 3455, 1611, $739 \mathrm{~cm}^{-1} ;{ }^{1} \mathrm{H} \delta 12.23(1 \mathrm{H}, \mathrm{br} \mathrm{s}, \mathrm{NH}), 8.30(1 \mathrm{H}, \mathrm{d}, J=8.4 \mathrm{~Hz}), 8.22(1 \mathrm{H}$, $\mathrm{d}, J=8.2 \mathrm{~Hz}), 8.17(1 \mathrm{H}, \mathrm{d}, J=7.9 \mathrm{~Hz}), 7.77(1 \mathrm{H}, \mathrm{d}, J=7.6 \mathrm{~Hz}), 7.6-7.48(3 \mathrm{H}, \mathrm{m}), 7.31(1 \mathrm{H}, \mathrm{t}$, $J=7.6 \mathrm{~Hz}), 3.65(2 \mathrm{H}, \mathrm{t}, J=8.0 \mathrm{~Hz}), 1.98(2 \mathrm{H}$, sextet, $J=7.6 \mathrm{~Hz}), 1.24(3 \mathrm{H}, \mathrm{t}, J=7.4 \mathrm{~Hz}) ;{ }^{13} \mathrm{C}$ $\delta 153.44,146.26,144.31,141.38,128.71,127.45,127.04,124.17,123.41,122.67,121.39$, 119.99, 116.63, 110.93, 30.93, 22.92, 14.70; MS m/z $260\left(\mathrm{M}^{+}\right)$, 231. Anal. Calcd for $\mathrm{C}_{18} \mathrm{H}_{16} \mathrm{~N}_{2}$ : C, 83.05; H, 6.19; N, 10.76. Found: C, 82.86; H, 6.16; N, 10.67 .

The indoloquinoline 131d (72\% yield) was also synthesized in a one-pot operation from 103d and phenyl isocyanate without isolation of $\mathbf{1 2 6 d}$.

11-Phenyl-6H-indolo[2,3-b]quinoline (131e).$^{58}$ A solution of $0.188 \mathrm{~g}$ of $\mathbf{1 2 6 e}(0.639 \mathrm{mmol})$ in $2.0 \mathrm{~mL}$ of anhydrous benzene was heated under reflux for $4 \mathrm{~h}$. The reaction mixture was then concentrated, and the residue was purified by flash chromatography (silica gel/20-50\% diethyl ether in hexanes) to furnish $0.171 \mathrm{~g}(0.582 \mathrm{mmol}, 91 \%)$ of $131 \mathrm{e}$ as bright pale yellow crystals: mp 266-268 ${ }^{\circ} \mathrm{C}$ (lit. $\left.{ }^{58} 269-271{ }^{\circ} \mathrm{C}\right)$; IR (KBr) 1593, $743 \mathrm{~cm}^{-1} ;{ }^{1} \mathrm{H} \delta 12.46(1 \mathrm{H}, \mathrm{br} \mathrm{s}, \mathrm{NH}), 8.28(1$ $\mathrm{H}, \mathrm{d}, J=8.4 \mathrm{~Hz}), 7.81-7.73(3 \mathrm{H}, \mathrm{m}), 7.7-7.65(3 \mathrm{H}, \mathrm{m}), 7.57-7.52(3 \mathrm{H}, \mathrm{m}), 7.44-7.37(2 \mathrm{H}, \mathrm{m})$, $7.08(1 \mathrm{H}, \mathrm{d}, J=7.4 \mathrm{~Hz}), 6.98(1 \mathrm{H}, \mathrm{td}, J=7.5$ and $1.1 \mathrm{~Hz}),{ }^{13} \mathrm{C} \delta 153.36,146.18,142.80$, 
$141.55,136.37,129.35,128.95,128.55,127.87,126.59,126.40,123.69,123.06,122.85,121.04$, 119.70, 116.75, 110.79; MS m/z $294\left(\mathrm{M}^{+}\right), 293,264,146$. Anal. Calcd for $\mathrm{C}_{21} \mathrm{H}_{14} \mathrm{~N}_{2}$ : C, 85.69; $\mathrm{H}$, 4.79; N, 9.52. Found: C, 85.74; H, 4.84; N, 9.50.

The indoloquinoline 131e (67\% yield) was also synthesized in a one-pot operation from 103e and phenyl isocyanate without isolation of $\mathbf{1 2 6 e}$.

11-Methyl-6H-indolo[2,3-b]quinoline (131f). ${ }^{56}$ A solution of $0.160 \mathrm{~g}$ of $\mathbf{1 2 6 f}(0.690 \mathrm{mmol})$ in $1.0 \mathrm{~mL}$ of $p$-xylene was heated at $138{ }^{\circ} \mathrm{C}$ for $4 \mathrm{~h}$. The reaction mixture was then concentrated, and the residue was purified by flash chromatography (silica gel/40-60\% diethyl ether in hexanes) to furnish $0.123 \mathrm{~g}(0.530 \mathrm{mmol}, 77 \%)$ of $\mathbf{1 3 1 f}$ as pale yellow crystals: IR (KBr) 3423, 1476, 1398, 1171, 1036, $805 \mathrm{~cm}^{-1} ;{ }^{1} \mathrm{H} \delta 10.16(1 \mathrm{H}, \mathrm{br} \mathrm{s}, \mathrm{NH}), 8.30(2 \mathrm{H}, \mathrm{d}, J=7.9 \mathrm{~Hz}), 8.14$ (1 $\mathrm{H}, \mathrm{d}, J=8.4 \mathrm{~Hz}), 7.77(1 \mathrm{H}, \mathrm{ddd}, J=8.2,6.9$, and $1.4 \mathrm{~Hz}), 7.57-7.51(3 \mathrm{H}, \mathrm{m}), 7.33(1 \mathrm{H}, \mathrm{dd}, J=$ 7.7 and $4.0 \mathrm{~Hz}), 3.24(3 \mathrm{H}, \mathrm{s}) ;{ }^{1} \mathrm{H} \delta\left(\mathrm{DMSO}-d_{6}\right) 11.66(1 \mathrm{H}, \mathrm{br} \mathrm{s}, \mathrm{NH}), 8.34(1 \mathrm{H}, \mathrm{d}, J=7.7 \mathrm{~Hz})$, $8.32(1 \mathrm{H}, \mathrm{d}, J=7.7 \mathrm{~Hz}), 7.95(1 \mathrm{H}, \mathrm{d}, J=8.4 \mathrm{~Hz}), 7.71(1 \mathrm{H}, \mathrm{td}, J=7.7$ and $1.1 \mathrm{~Hz}), 7.55-7.46$ $(3 \mathrm{H}, \mathrm{m}), 7.27(1 \mathrm{H}, \mathrm{td}, J=7.2$ and $2.0 \mathrm{~Hz}), 3.17(3 \mathrm{H}, \mathrm{s}) ;{ }^{13} \mathrm{C} \delta$ (DMSO- $\left.d_{6}\right) 152.33,146.19$, 141.32, 138.68, 128.45, 127.49 (two overlapping signals), 124.44, 123.72, 123.46, 122.46, 121.05, 119.62, 115.95, 110.71, 14.87; MS m/z $232\left(\mathrm{M}^{+}\right), 231$.

The indoloquinoline $131 \mathrm{f}(59 \%)$ was also synthesized in a one-pot operation from $103 f$ and phenyl isocyanate without isolation of $\mathbf{1 2 6 f}$.

2-Methoxy-11-propyl-6H-indolo[2,3-b]quinoline (142d). To a solution of $0.650 \mathrm{~g}$ of $\mathbf{1 0 3 d}$ $(1.55 \mathrm{mmol})$ in $10 \mathrm{~mL}$ of anhydrous $p$-xylene was added via cannula a solution of $0.231 \mathrm{~g}$ of 4 methoxyphenyl isocyanate $(1.55 \mathrm{mmol}) \mathrm{in} 10 \mathrm{~mL}$ of anhydrous $p$-xylene under a nitrogen atmosphere. The reaction mixture was heated under reflux for $5 \mathrm{~h}$ and then concentrated. The residue was purified by flash chromatography (silica gel/20-50\% diethyl ether in hexanes) to 
afford $0.212 \mathrm{~g}(0.731 \mathrm{mmol}, 47 \%)$ of $\mathbf{1 4 2 d}$ as a pale yellow solid: $\mathrm{mp} 236-238{ }^{\circ} \mathrm{C}$; IR $(\mathrm{KBr})$ $3417,1633,1613,1232,823,724 \mathrm{~cm}^{-1} ;{ }^{1} \mathrm{H} \delta 9.66$ (1 H, br s, NH), $8.18(1 \mathrm{H}, \mathrm{d}, J=7.9 \mathrm{~Hz}), 8.04$ $(1 \mathrm{H}, \mathrm{d}, J=9.2 \mathrm{~Hz}), 7.56-7.49(3 \mathrm{H}, \mathrm{m}), 7.45(1 \mathrm{H}, \mathrm{dd}, J=9.2$ and $2.6 \mathrm{~Hz}), 7.34-7.28(1 \mathrm{H}, \mathrm{m})$, $4.01(3 \mathrm{H}, \mathrm{s}), 3.62(2 \mathrm{H}, \mathrm{t}, J=8.0 \mathrm{~Hz}), 1.98(2 \mathrm{H}$, sextet, $J=7.6 \mathrm{~Hz}), 1.23(3 \mathrm{H}, \mathrm{d}, J=7.4 \mathrm{~Hz})$; ${ }^{13} \mathrm{C}\left(\mathrm{DMSO}-d_{6}\right) \delta 154.70,151.30,142.14,141.53,141.34,128.97,127.31,123.25,120.56$, $120.27,119.44,115.43,110.68,102.60,55.37,29.95,22.27,14.21 ; \mathrm{MS} m / z 290\left(\mathrm{M}^{+}\right), 275,261$, 246, 218; HRMS calcd for $\mathrm{C}_{19} \mathrm{H}_{18} \mathrm{~N}_{2} \mathrm{O} 290.1419$, found 290.1420 .

2-Methoxy-11-phenyl-6H-indolo[2,3-b]quinoline (142e) ${ }^{49 \mathrm{~b}}$ The same procedure was repeated as described for 142d except that $0.500 \mathrm{~g}$ of $56 \mathrm{e}(1.10 \mathrm{mmol})$ in $6 \mathrm{~mL}$ of anhydrous benzene and $0.164 \mathrm{~g}$ of 4-methoxyphenyl isocyanate $(1.10 \mathrm{mmol})$ in $9 \mathrm{~mL}$ of anhydrous benzene were used to afford $0.194 \mathrm{~g}(0.599 \mathrm{mmol}, 55 \%)$ of $\mathbf{1 4 2 e}$ as bright pale yellow crystals: IR (KBr) 3431, 3077, 1630, 1608, 821, $744 \mathrm{~cm}^{-1} ;{ }^{1} \mathrm{H} \delta 11.46(1 \mathrm{H}, \mathrm{br} \mathrm{s}, \mathrm{NH}), 8.15(1 \mathrm{H}, \mathrm{d}, J=9.2 \mathrm{~Hz}), 7.72-7.64(3 \mathrm{H}$, m), 7.57-7.53 (2 H, m), 7.50 (1 H, s), 7.47-7.39 $(2 \mathrm{H}, \mathrm{m}), 7.07(1 \mathrm{H}, \mathrm{d}, J=2.9 \mathrm{~Hz}), 7.04(1 \mathrm{H}$, $\mathrm{dm}, J=7.6$ and $0.8 \mathrm{~Hz}), 6.97(1 \mathrm{H}, \mathrm{ddd}, J=8.4,6.9$, and $1.1 \mathrm{~Hz}), 3.78(3 \mathrm{H}, \mathrm{s}) ;{ }^{13} \mathrm{C} \delta 155.29$, $152.09,142.15,141.47,141.39,136.59,129.26,129.10,128.56,127.96,127.81,124.28,123.11$, 121.14, 120.99, 119.59, 116.72, 110.63, 104.77, 55.44; MS m/z $324\left(\mathrm{M}^{+}\right), 309$, 292. Anal. Calcd for $\mathrm{C}_{22} \mathrm{H}_{16} \mathrm{~N}_{2} \mathrm{O}: \mathrm{C}, 81.46 ; \mathrm{H}, 4.97 ; \mathrm{N}$, 8.64. Found: $\mathrm{C}, 81.55 ; \mathrm{H}, 5.00 ; \mathrm{N}, 8.57$.

2-(1-Propynyl)phenyl Isocyanate (163). To a solution of $1.089 \mathrm{~g}$ of triphosgene $(3.67 \mathrm{mmol})$ in $20 \mathrm{~mL}$ of anhydrous benzene was added dropwise a mixture of $1.310 \mathrm{~g}$ of $\mathbf{1 0 2 f}(10.0 \mathrm{mmol})$ and $2.78 \mathrm{~mL}$ of anhydrous triethylamine $(20.0 \mathrm{mmol})$ in $30 \mathrm{~mL}$ of anhydrous benzene under a nitrogen atmosphere at $\mathrm{rt}$. After $2 \mathrm{~h}$ at $70{ }^{\circ} \mathrm{C}$, the white precipitate of triethylamine hydrochloride was removed by filtration and the filtrate was concentrated in vacuo. The residue was purified by flash chromatography (silica gel/10-20\% of diethyl ether in hexanes) to give 
$1.507 \mathrm{~g}$ of $\mathbf{1 6 3}$ (9.60 mmol, 96\%) as a light yellow liquid: IR (neat) 2241, 1723, $755 \mathrm{~cm}^{-1} ;{ }^{1} \mathrm{H} \delta$ $7.37(1 \mathrm{H}, \mathrm{dd}, J=7.5$ and $1.6 \mathrm{~Hz}), 7.21(1 \mathrm{H}, \mathrm{td}, J=7.7$ and $1.7 \mathrm{~Hz}), 7.10(1 \mathrm{H}, \mathrm{td}, J=7.5$ and $1.3 \mathrm{~Hz}), 7.00(1 \mathrm{H}, \mathrm{dd}, J=7.9$ and $1.5 \mathrm{~Hz}), 2.13(3 \mathrm{H}, \mathrm{s}) ;{ }^{13} \mathrm{C} \delta 135.4,131.8,128.6,127.7$, 125.2, 123.3, 121.5, 95.4, 75.7, 4.4; MS m/z $157\left(\mathrm{M}^{+}\right), 129,102$; HRMS calcd for $\mathrm{C}_{10} \mathrm{H}_{7} \mathrm{NO}$ 157.0528, found 157.0525 .

\section{1-Methyl-6H-indolo[2,3-b][1,5]naphthyridine (169) and 5-Methyl-10H-indolo[2,3-} b][1,7]naphthyridine (170). ${ }^{69}$ To a solution of $0.708 \mathrm{~g}$ of $\mathbf{1 6 4}(2.00 \mathrm{mmol})$ in $3 \mathrm{~mL}$ of anhydrous benzene was added $0.314 \mathrm{~g}$ of $\mathbf{1 6 3}(2.00 \mathrm{mmol})$ in $7 \mathrm{~mL}$ of anhydrous benzene via cannula under a nitrogen atmosphere at rt. After $2 \mathrm{~h}$ at $\mathrm{rt}$, the reaction mixture was filtered through a short silica gel column to remove triphenylphosphine oxide. The column was further eluded with $p$-xylene. The combined benzene and $p$-xylene solutions were concentrated in vacuo to remove benzene. The remaining $p$-xylene solution was heated to reflux under a nitrogen atmosphere for $12 \mathrm{~h}$. The reaction mixture was concentrated in vacuo, and the residue was purified by flash chromatography (silica gel/12:7:1 of hexanes : diethyl ether : methanol) followed by preparative thin layer chromatography to furnish $0.272 \mathrm{~g}(1.17 \mathrm{mmol}, 58 \%)$ of $\mathbf{1 6 9}$ and $0.081 \mathrm{~g}(0.35 \mathrm{mmol}, 17 \%)$ of $\mathbf{1 7 0}$ as pale yellow crystals. 169: IR (KBr) 1610, 1407, 734 $\mathrm{cm}^{-1} ;{ }^{1} \mathrm{H} \delta 9.73(1 \mathrm{H}, \mathrm{br}, \mathrm{s}, \mathrm{NH}), 8.95(1 \mathrm{H}, \mathrm{dd}, J=4.0$ and $1.7 \mathrm{~Hz}), 8.33(1 \mathrm{H}, \mathrm{dd}, J=8.6$ and 1.7 $\mathrm{Hz}), 8.30(1 \mathrm{H}, \mathrm{d}, J=7.7 \mathrm{~Hz}), 7.62(1 \mathrm{H}, \mathrm{dd}, J=8.5$ and $4.1 \mathrm{~Hz}), 7.55(1 \mathrm{H}, \mathrm{td}, J=7.5$ and 1.1 $\mathrm{Hz}), 7.50(1 \mathrm{H}, \mathrm{d}, J=7.2 \mathrm{~Hz}), 7.35(1 \mathrm{H}, \mathrm{ddd}, J=7.5,6.9$, and $1.6 \mathrm{~Hz}), 3.37(3 \mathrm{H}, \mathrm{s}) ;{ }^{13} \mathrm{C} \delta$ (DMSO-d $\left.{ }_{6}\right) 152.1,146.2,141.7,141.3,140.0,139.0,135.0,128.1,124.0,123.5,121.0,120.0$, 118.6, 110.9, 13.4; $\mathrm{MS} \mathrm{m} / z 233\left(\mathrm{M}^{+}\right), 205,152$; HRMS calcd for $\mathrm{C}_{15} \mathrm{H}_{11} \mathrm{~N}_{3} 233.0953$, found 233.0954. Anal. Calcd for $\mathrm{C}_{15} \mathrm{H}_{11} \mathrm{~N}_{3}: \mathrm{C}, 77.23 ; \mathrm{H}, 4.75 ; \mathrm{N}, 18.01$. Found: $\mathrm{C}, 76.95 ; \mathrm{H}, 4.83 ; \mathrm{N}$, 17.76. 170: IR (KBr) 1615, $742 \mathrm{~cm}^{-1} ;{ }^{1} \mathrm{H} \delta\left(\mathrm{DMSO}_{6}\right) 11.97(1 \mathrm{H}, \mathrm{s}), 9.32(1 \mathrm{H}, \mathrm{s}), 8.51(1 \mathrm{H}, \mathrm{d}$, 
$J=5.7 \mathrm{~Hz}), 8.39(1 \mathrm{H}, \mathrm{d}, J=7.7 \mathrm{~Hz}), 8.21(1 \mathrm{H}, \mathrm{d}, J=5.7 \mathrm{~Hz}), 7.60(1 \mathrm{H}, \mathrm{t}, J=7.5 \mathrm{~Hz}), 7.54(1$ $\mathrm{H}, \mathrm{d}, J=7.2 \mathrm{~Hz}), 7.32(1 \mathrm{H}, \mathrm{t}, J=7.3 \mathrm{~Hz}), 3.18(3 \mathrm{H}, \mathrm{s}) ;{ }^{13} \mathrm{C} \delta$ (DMSO- $\left.d_{6}\right) 152.8,151.7,142.0$, 139.6, 137.8, 128.7, 126.3, 124.5, 120.4, 120.1, 119.1, 117.0, 111.0, 14.4; MS m/z $233\left(\mathrm{M}^{+}\right)$, 205, 151; HRMS calcd for $\mathrm{C}_{15} \mathrm{H}_{11} \mathrm{~N}_{3} 233.0953$, found 233.0950. 


\section{References:}

(1) (a) Wang, K. K. Chem. Rev. (Washington, D.C.) 1996, 96, 207-222. (b) Grissom, J. W.;

Gunawardena, G. U.; Klingberg, D.; Huang, D. Tetrahedron 1996, 52, 6453-6518. (c) Maier, M.

E. Synlett 1995, 13-26. (d) Nicolaou, K. C. ; Dai, W.-M. Angew. Chem. Int. Ed. Engl. 1991, $30,1387-1530$.

(2) (a) Wang, Y.; Finn, M. G. J. Am. Chem. Soc. 1995, 117, 8045-8046. (b) Miyawaki, K.; Suzuki, R.; Kawano, T.; Ueda, I. Tetrahedron Lett. 1997, 38, 3943-3946.

(3) (a) Lee, M. D.; Dunne, T. S. ; Siegel, M. M.; Chang, C. C.; Morton, G. O.; Borders, D. B. J. Am. Chem. Soc. 1987, 109,3464-3466. (b) Lee, M. D.; Dunne, T. S.; Chang, C. C.; Ellestad, G. A.; Siegel, M. M.; Morton, G. O.; McGahren, W. J.; Borders, D. B. J. Am. Chem. Soc. 1987, $109,3466-3468$.

(4) (a) Golic, J.; Clardy, J.; Dubay, G.; Groenewold, G.; Kawaguchi, H.; Konish, M.; Krishnan, B.; Ohkuma, H.; Saioh, K.; Doyle, T. W. J. Am. Chem. Soc. 1987, 109,3461-3462. ) (b) Golic, J.; Dubay, G.; Groenewold, G.; Kawaguchi, H.; Konish, M.; Krishnan, B.; Ohkuma, H.; Saioh, K.; Doyle, T. W. J. Am. Chem. Soc. 1987, 109, 3462-3464.

(5) (a) Konish, M.; Ohkuma, H.; Matsumoto, K.; Tsuno, T.; Kamei, H.; Miyaki, T.; Oki, T.; Kawaguchi, H.; Van, Duyne, G. D.; Clardy, J. J. Antibiotics 1989, 42, 1449-1452. (b) Konish, M.; Ohkuma, H.; Tsuno, T.; Oki, T.; Van, Duyne, G. D.; Clardy, J. J. Am. Chem. Soc. 1990, 112, 3715-3716.

(6) Yoshida, k.; Minami, Y.; Azuma, R.; Saeki, M.; Otani, T. Tetrahedron Lett. 1993, 347, 26372640.

(7) (a) Lam, K. S.; Hesler, G. A.; Gustavson, D. R.; Crosswell, A. R.; Veitch, J. M.; Forenza, S.; Tomita, K. J. Antibiotics 1991, 44, 472-478. (b) Leet, J. E.; Schroeder, D. R.; Hofstead, S. J.; 
Golik, J.; Colson, K. L.; Huang, S.; Klohr, S. E.; Doyle, T. W.; Matson, J. A. J. Am. Chem. Soc. 1992, 114, 7946-7948.

(8) (a) Ishida, N.; Miyazaki, K.; Kumagai, K. M.; Rikimura, M. J. Antibiotics 1965, 18, 68-76.

(b) Goldberg, I. H. Acc. Chem. Res. 1991, 24, 191-198.

(9) (a) Jones, R. R.; Bergman, R. G. J. Am. Chem. Soc. 1972, 94, 660-661. (b) Lockhart, T. P.;

Comita, P. B.; Bergman, R. G. J. Am. Chem. Soc. 1981, 103, 4082-4090. (c) Bharucha, K. N.;

Marsh, R. M.; Minto, R. E.; Bergman, R. G. J. Am. Chem. Soc. 1992, 114, 3120-3121. For

recent reviews, see: (1a) and (1b).

(10) (a) Myers, A. G.; Kuo, E. Y.; Finney, N. S. J. Am. Chem. Soc. 1989, 111, 8057-8059. (b)

Myers, A. G.; Dragovich, P. S. J. Am. Chem. Soc. 1989, 111, 9130-9132. (c) Nagata, R.; Yamanaka, H.; Okazaki, E.; Saito, I. Tetrahedron Lett. 1989, 30, 4995-4998. (d) Nagata, R.; Yamanaka, H.; Murahashi, E.; Saito, I. Tetrahedron Lett. 1990, 31, 2907-2910. (e) Wang, K. K.; Wang, Z.; Tarli, A.; Gannett, P. J. Am. Chem. Soc. 1996, 118, 10783-10791 and references cited therein. (f) Grissom, J. W.; Klingberg, D.; Huang, D.; Slattery, B. J. J. Org. Chem. 1997, 62, 603-626 and references cited therein.

(11) Darby, N.; Kim, C. U.; Salaün, J. A.; Shelton, K. W.; Takada, S.; Masamune, S. Chem. Commun. 1971, 1516-1517.

(12) Myers, A. G. Tetrahedron Lett. 1987, 28, 4493-4496.

(13) (a) Nakatani, K.; Isoe, S.; Maekawa,S.; Saito, I. Tetrahedron Lett. 1994, 35, 605-608. (b) Sullivan, R. W.; Coghlan, V. M.; Munk, S. A.; Reed, M. W.; Moore, H. W. J. Org. Chem. 1994, 59, 2276-2278.

(14) Toda, F.; Tanaka, K.; Sano, I.; Isozaki, T. Angew. Chem. Int. Ed. Engl. 1994, 33, 17571758. 
(15) Nicolaou, K. C. ; Skokotas, G.; Maligres, P.; Zuccarello, G.; Schweiger, E. J.; Toshima, K.; Wendeborn, S. Angew. Chem. Int. Ed. Engl. 1989, 28, 1272-1275.

(16) (a) Moore, H. W.; Yerxa, B. R. Chemtracts 1992, 273-313. (b) Tarli, A.; Wang, K. K. J. Org. Chem. 1997, 62, 8841-8847.

(17) (a) Wang, K. K.; Wang, Z.; Sattsangi, P. D. J. Org. Chem. 1996, 61, 1516-1518. (b) Gillmann, T.; Heckhoff, S. Tetrahedron Lett. 1996, 37, 839-840.

(18) (a) David, W. M.; Kerwin, S. M. J. Am. Chem. Soc. 1997, 119, 1464-1465. (b) Hoffner, J.; Schottelius, M. J.; Feichtinger, D.; Chen, P. J. Am. Chem. Soc. 1998, 120, 376-385.

(19) (a) Foland, L. D.; Karlsson, J. O.; Perri, S. T.; Schwabe, R.; Xu, S. L.; Patil, S.; Moore, H. W. J. Am. Chem. Soc. 1989, 111, 975-989. (b) Perri, S. T.; Foland, L. D.; Moore, H. W. Tetrahedron Lett. 1988, 29, 3529-3532.

(20) Xia, H.; Moore, H. W. J. Org. Chem. 1992, 57, 3765-3766.

(21) (a) Schmittel, M.; Strittmatter, M.; Kiau, S. Angew. Chem., Int. Ed. Engl. 1996, 35, 18431845. (b) Schmittel, M.; Kiau, S.; Siebert, T.; Strittmatter, M. Tetrahedron Lett. 1996, 37, 76917694. (c) Schmittel, M.; Strittmatter, M.; Vollmann, K.; Kiau, S. Tetrahedron Lett. 1996, 37, 999-1002. (d) Schmittel, M.; Maywald, M.; Strittmatter, M. Synlett 1997, 165-166. (e) Schmittel, M.; Strittmatter, M.; Kiau, S. Tetrahedron Lett. 1995, 36, 4975-4978.

(22) For the trapping of the different types of 1,4-diradical intermediates also see: (a) Griller, D.; Ingold, K. U.; Acc. Chem. Res. 1980, 13, 317-323. (b) Newcomb, M.; Johnson, C. C.; Manek, M. B.; Varick, T. R. J. Am. Chem. Soc. 1992, 114, 10915-10921. (c) Becker, D.; Denekamp, C.; Haddad, N. Tetrahedron Lett. 1992, 33, 827-830. (d) Cheng, K.-L.; Wagner, P. J. J. Am. Chem. Soc. 1994, 116, 7945-7946. (e) Maradyn, D. J.; Weedon, A. C. J. Am. Chem. Soc. 1995, 117, 
5359-5360. (f) Ciufolini, M. A.; Rivera-Fortin, M. A.; Zuzukin, V.; Whitmire, K. H. J. Am. Chem. Soc. 1994, 116, 1272-1277.

(23) (a) Benati, L.; Leardini, R.; Minozzi, M.; Nanni, D.; Spagnolo, P.; Zanardi, G. J. Org.

Chem. 2000, 65, 8669-8674. (b) Leardini, R.; Pedulli, G. F.; Zanardi, G. J. Chem. Soc., Chem.

Commun. 1984, 1320-1321. (c) Leardini, R.; Nanni, D.; Pedulli, G. F.; Tundo, A.; Zanardi, G. J.

Chem. Soc., Perkin Trans. 1 1986, 1591-1594. (d) Montevecchi, P. C.; Navacchia, M. L. J. Org. Chem. 1998, 63, 537-542.

(24) Gillmann, T.; Hulsen, T.; Massa, W.; Wocadlo, S. Synlett 1995, 1257-1259.

(25) (a) Differding, E.; Ghosez, L. Tetrahedron Lett. 1985, 26, 1647-1650. (b) Alajarín, M.;

Molina, P.; Vidal, A. J. Nat. Prod. 1997, 60, 747-748. (c) Shi, C.; Wang, K. K. J. Org. Chem.

1998, 63, 3517-3520. (d) Shi, C.; Zhang, Q.; Wang, K. K. J. Org. Chem. 1999, 64, 925-932. (e)

Zhang, Q.; Shi, C.; Zhang, H.-R.; Wang, K. K. J. Org. Chem. 2000, 65, 7977-7983. (f)

Schmittel, M.; Steffen, J.-P.; Angel, M. A. W.; Engels, B.; Lennartz, C.; Hanrath, M. Angew.

Chem., Int. Ed. Engl. 1998, 37, 1562-1564. (g) Schmittel, M.; Steffen, J.-P.; Engels, B.;

Lennartz, C.; Hanrath, M. Angew. Chem., Int. Ed. Engl. 1998, 37, 2371-2373. (h) Schmittel, M.;

Rodríguez, D.; Steffen, J.-P. Angew. Chem., Int. Ed. Engl. 2000, 39, 2152-2155.

(26) For the excellent comprehensive reviews see: (a) "Ketenimines and Their P, As, Sb, and Bi Analogues". Michael, J. P.; De Koning, C. B. In Comprehensive Organic Functional Group Transformations, Alan R. Katritzky, Otto Meth-Cohn and Charles W. Rees, Editors-in Chief; Elsevier: Oxford, UK., 1995; Vol. 3, 555-610. (b) "Functions with at Least One Nitrogen and No Chalcogens". Muthyala, R. In Comprehensive Organic Functional Group Transformations, Alan R. Katritzky, Otto Meth-Cohn and Charles W. Rees, Editors-in Chief; Elsevier: Oxford, UK., 1995; Vol. 5, 1061-1089. 
(27) Stevens, C. L.; Singhal, G. H. J. Org. Chem. 1964, 29, 34-37.

(28) (a) Bestmann, H. J.; Lienert, J.; Mott, L. Liebigs Ann. Chem. 1968, 718, 24-32. (b)

Goerdeler, J.; Lindner, C. Tetrahedron Lett. 1972, 16, 1519-1520.

(29) Stevens, C. L.; French, J. J. Am. Chem. Soc. 1954, 76, 4398-4002.

(30) Taylor, A. W.; Burton, G. Tetrahedron Lett. 1977, 18, 3831-3834.

(31) It is noteworthy that both (trimethylsilyl)ketene and bis(trimethylsilyl)ketene are reasonably thermal stable compounds because trimethylsily group can be treated as "masked hydrogen atom". For the preparation see: (a) Sakurai, H.; Shirahata, A.; Sasaki, K.; Hosomi, A. Synthesis, 1979, 740-741. (b) Groh, B. L.; Magrum, G. R.; Barton, T. J. J. Am. Chem. Soc. 1987, 109, 7568-7569. (c) Valenti, E.; Pericãs, M. A.; Serratosa, F. J. Org. Chem. 1990, 55, 395-397. (d) Phenyl-(trimethylsily)-ketene is another interesting one. For the preparation see: Hoppe, I.; Schöllkopf, U. Liebigs Ann. Chem. 1979, 219-226.

(32) (a) Molina, P.; Alajarin, M.; Vidal, A.; Feneau-Dupont, J.; Declecq, J. P. J. Chem. Soc., Chem. Commun. 1990, 829-831. (b) Molina, P.; Alajarin, M.; Vidal, A.; Feneau-Dupont, J.; Declecq, J. P. J. Org. Chem. 1991, 56, 4008-4016.

(33) Bödeker,J.; Courault, K.; Köckritz, P. Z. Chem. 1980, 20, 211-212.

(34) Ciganek, E. J. Org. Chem. 1970, 35, 862.

(35) Pascual, A. Helv. Chim. Acta 1989, 72, 556-569.

(36) (a) Manley, P. W.; Quast, U. J. Med. Chem. 1992, 35, 2327-2340. (b) Taniguchi, K.; Shigenaga, S.; Ogahara, T.; Fujitsu, T.; Matsuo, M. Chem. Pharm. Bull. 1993, 41, 301-309.

(37) Isobe, T.; Ishikawa, T. J. Org. Chem. 1999, 64, 6984-6988.

(38) Fell, J. B.; Coppola, G. M. Synth. Commun. 1995, 25, 43-47. 
(39) For a review about "six-membered heterocyclic isocyanates and isothiocyanates" see:

Labbé, G. Synthesis, 1987, 525-531.

(40) Trifonov, L. S.; Orahovats, A. S. Helv. Chim. Acta 1987, 70, 262-270.

(41) Bödeker, J.; Courault, K.; Köckritz, A.; Köckritz, P. J. Prakt. Chem. 1983, 325, 463-474.

(42) Bödeker,J.; Köckritz, P.; Courault, K. Z. Chem. 1979, 19, 59.

(43) Krow, G. R. Angew. Chem., Int. Ed. Engl. 1971, 10, 435-449.

(44) Bestmann, H. J. Angew. Chem., Int. Ed. Engl. 1977, 16, 349-364.

(45) (a) Gornowicz, G. A.; West, R. J. Am. Chem. Soc. 1971, 93, 1714-1721. (b) Lage, N.; Masson, S.; Thuillier, A. Phosphorus, Sulfur and Silicon 1991, 59, 141-144. (c) Molina, P.; Vidal, A.; Barquero, I. Synthesis, 1986, 1199-1202. (d) Barbaro, G.; Battaglia, A.; Giorgianni, P.; Guerrini, A.; Seconi, G. J. Org. Chem. 1995, 60, 6032-6039.

(46) Serferth, D.; Langer, P.; Döring, M. Organomettallics 1995, 14, 4457-4459.

(47) Grissom, J. W.; Calkins, T. L.; McMillen, H. A.; Jiang, Y. J. Org. Chem. 1994, 59, 58335935.

(48) (a) Villemin, D.; Goussu, D. Heterocycles, 1989, 29, 1255-1261. (b) Arcadi, A.; Cacchi, S.; Marinelli, F. Tetrahedron Lett. 1989, 30, 2581-2584. (c) Iritani, K.; Matsubara, S.; Utimoto. K. Tetrahedron Lett. 1988, 29, 1799-1802.

(49) (a) Molina, P.; Alajarin, M.; Vidal, A. J. Chem. Soc., Chem. Commun. 1990, 1277-1279. (b) Molina, P.; Alajarin, M.; Vidal, A.; Sanchez-Andrada, P. J. Org. Chem. 1992, 57, 929-939.

(50) Taylor, E. C.; McKillop, A.; Hawks, G, H. Org. Synth. 1972, 52, 36-38.

(51) IR absorbance (A) at $2002 \mathrm{~cm}^{-1}$ at different reaction time was recorded in the following Table. 


\begin{tabular}{|c|c|c|c|}
\hline A & Time, $\min$ & Time, $\mathrm{hr}$ & $-\operatorname{In} \mathrm{A}$ \\
\hline 0.5366 & 20 & 0.33333 & 0.6225 \\
\hline 0.339 & 35 & 0.58333 & 1.0818 \\
\hline 0.2079 & 51 & 0.85 & 1.5707 \\
\hline 0.1305 & 65 & 1.08333 & 2.0364 \\
\hline 0.07405 & 82 & 1.36667 & 2.603 \\
\hline 0.04072 & 103 & 1.71667 & 3.201 \\
\hline
\end{tabular}

Lambert-Beer law establishes a relationship between the transmittance, the sample thickness, and the concentration of the absorbing species. This relationship is expressed as

$$
\log (1 / \mathrm{T})=\log _{10}\left(\mathrm{I}_{0} / \mathrm{I}\right)=\mathrm{abC}=\mathrm{A}
$$

where $\mathrm{T}=$ transmittance,

$\mathrm{I}_{0}=$ the intensity of the radiant energy striking the sample,

$\mathrm{I}=$ the intensity of the radiation emerging from the sample,

$\mathrm{a}=\mathrm{a}$ constant characteristic of the solute,

$\mathrm{b}=$ path length through the sample,

$\mathrm{C}=$ concentration of solute,

$\mathrm{A}=$ absorbance.

For the first-order reaction, the relationship between the concentration of the reactant and the reaction time is expressed as: $\ln \left(\mathrm{C}_{0} / \mathrm{C}\right)=\mathrm{kt}$ or $\ln \mathrm{C}=-\mathrm{kt}+\ln \mathrm{C}_{0}$

Where $\mathrm{t}=$ reaction time,

$$
\begin{aligned}
& \mathrm{C}_{0}=\text { initial concentration of the reactant, } \\
& \mathrm{C}=\text { the concentration of the reactant at time } \mathrm{t} .
\end{aligned}
$$

We can combine the above two equations and get the following new equation:

$$
\begin{gathered}
-\ln \mathrm{C}=\ln \mathrm{A}+\ln (\mathrm{ab})=\mathrm{kt}+\ln \mathrm{C}_{0} \\
\text { or }-\ln \mathrm{A}=\mathrm{kt}+\ln \left(\mathrm{abC}_{0}\right)
\end{gathered}
$$

(52) Garcia, J. G.; Ramos, B.; Pratt, L. M.; Rodriguez, A. Tetrahedron Lett. 1995, 36, 73917394.

(53) Molina, P.; Lopez-Leonardo, C.; Alcantara, J. Tetrahedron 1994, 50, 5027-5036.

(54) The relative concentration $\mathrm{C}_{0} / \mathrm{C}$ of reactant $\mathbf{1 0 4 b}$ was represented as $(\mathrm{A}+\mathrm{B}) / \mathrm{A}$ :

$\mathrm{A}$ and $\mathrm{B}$ were the integrations of ${ }^{1} \mathrm{H}$ NMR absorptions at $\delta 1.25(\mathrm{~A})$ and at $\delta 2.06(\mathrm{~B})$, respectively (A: attributable to tert-butyl of 104b; B: attributable to tert-butyl of $\mathbf{1 0 9 b}$ ). 


\begin{tabular}{|c|c|c|c|c|}
\hline diminishing $\mathrm{A}$ & developing $\mathrm{B}$ & $(\mathrm{A}+\mathrm{B}) / \mathrm{A}$ & Time, $\mathrm{hr}$ & $\ln [(\mathrm{A}+\mathrm{B}) / \mathrm{A}]$ \\
\hline 9 & 0.909 & 1.1010 & 0.5 & 0.0962 \\
\hline 9 & 2.831 & 1.3146 & 1.5 & 0.2735 \\
\hline 9 & 9.011 & 2.0012 & 3.75 & 0.6938 \\
\hline 3.446 & 9 & 3.6117 & 7 & 1.2842 \\
\hline 1.163 & 9 & 8.7386 & 11.5 & 2.1678 \\
\hline
\end{tabular}

(55) The relative concentration $\mathrm{C}_{0} / \mathrm{C}$ of reactant $\mathbf{1 0 4 c}$ was represented as $(\mathrm{A}+\mathrm{B}) / \mathrm{A}$ :

$\mathrm{A}$ and $\mathrm{B}$ were the integrations of ${ }^{1} \mathrm{H}$ NMR absorptions at $\delta 0.25(\mathrm{~A})$ and at $\delta 0.78(\mathrm{~B})$,

respectively (A: attributable to trimethylsilyl of $\mathbf{1 0 4 c}$; B: attributable to trimethylsilyl of $\mathbf{1 0 4 c}$ ).

\begin{tabular}{|c|c|c|c|c|}
\hline diminishing $\mathrm{A}$ & developing $\mathrm{B}$ & $(\mathrm{A}+\mathrm{B}) / \mathrm{A}$ & $\mathrm{Time}, \mathrm{hr}$ & $\ln [(\mathrm{A}+\mathrm{B}) / \mathrm{A}]$ \\
\hline 9 & 4.54 & 1.5044 & 0.5 & 0.4084 \\
\hline 3.84 & 9 & 3.3438 & 1.5 & 1.2071 \\
\hline 1.85 & 9 & 5.8649 & 2.5 & 1.7690 \\
\hline
\end{tabular}

(56) Wilt, J. W.; Aznavoorian, P. M. J. Org. Chem. 1978, 43, 1285-1286.

(57) The relative concentration $\mathrm{C}_{0} / \mathrm{C}$ of reactant $\mathbf{1 0 4 d}$ was represented as $(\mathrm{A}+\mathrm{B}+2 \mathrm{C}) / \mathrm{A}$ :

$\mathrm{A}, \mathrm{B}$ and $\mathrm{C}$ were integrations of ${ }^{1} \mathrm{H} \mathrm{NMR}$ (in $\mathrm{C}_{6} \mathrm{D}_{6}$ and 1,4 -cyclohexadiene) absorptions at $\delta 1.09$ (A), 3.67 (B) and at $\delta 5.98(\mathrm{C})$, respectively (A: attributable to the propargylic methylene of 104d; B: attributable to the benzylic methylene of 109d and C: attributable to the methine hydrogen on the $\mathrm{sp}^{3}$ carbon of $\left.\mathbf{1 0 6} \mathbf{d}\right)$.

\begin{tabular}{|c|c|c|c|c|c|}
\hline diminishing A & developing $\mathrm{B}$ & developing $\mathrm{C}$ & $(\mathrm{A}+\mathrm{B}+2 \mathrm{C}) / \mathrm{A}$ & $\mathrm{Time}, \mathrm{hr}$ & $\ln [(\mathrm{A}+\mathrm{B}+2 \mathrm{C}) / \mathrm{A}]$ \\
\hline 1.812 & 0.4633 & 0.3849 & 1.6805 & 0.5 & 0.5191 \\
\hline 1.2757 & 0.7752 & 0.6425 & 2.6149 & 1 & 0.9612 \\
\hline 1.7063 & 2 & 1.8735 & 4.3681 & 1.5667 & 1.4743 \\
\hline 0.8914 & 2 & 1.9899 & 7.7083 & 2.233 & 2.0423 \\
\hline
\end{tabular}

(58) Bennett, J. E.; Howard, J. A. Chem. Phys. Lett. 1971, 9, 460-462.

(59) (a) Pindur, U.; Haber, M.; Erfanian-Abdoust, H. Heterocycles 1992, 34, 781-790. (b)

Pindur, U.; Erfanian-Abdoust, H. Chem. Rev. (Washington, D. C.) 1989, 89, 1681-1689. (c) 
Gribble, G. W.; Saulnier, M. G.; Obaza-Nutaitis, J. A.; Ketcha, D. M. J. Org. Chem. 1992, 57, 5891-5899. (d) Sha, C.-K.; Chuang, K.-S.; Wey, S.-J. J. Chem. Soc., Perkin Trans. 1 1987, 977980.

(60) (a) Saito, T.; Ohmori, H.; Furuno, E.; Motoki, S. J. Chem. Soc., Chem. Commun. 1992, 22-

24. (b) Saito, T.; Ohmori, H.; Ohkubo, T.; Motoki, S. J. Chem. Soc., Chem. Commun. 1993, 1802-1803.

(61 (a) Peczyńska-Czoch, W.; Pognan, F.; Kaczmarek, L.; Boratyński, J. J. Med. Chem. 1994, 37, 3503-3510. (b) Kaczmarek, L.; Balicki, R.; Nantka-Namirski, P.; Peczyńska-Czoch, W.; Mordarski, M. Arch. Pharm. (Weinheim) 1988, 321, 463-467.

(62) (a) Sharaf, M. H. M.; Schiff, P. L., Jr.; Tackie, A. N.; Phoebe, C. H., Jr.; Martin, G. E. J. Heterocycl. Chem. 1996, 33, 239-243. (b) Cimanga, K.; De Bruyne, T.; Pieters, L.; Claeys, M.; Vlietinck, A. Tetrahedron Lett. 1996, 37, 1703-1706.

(63) Molina, P.; Fresneda, P. M.; Delgado, S. Synthesis 1999, 326-329.

(64) Marsili, A. Tetrahedron 1968, 24, 4981-4991.

(65) Goodwin S.; Smith, A. F.; Horning, E. C. J. Am. Chem. Soc. 1959, 81, 1903-1908.

(66) Dalton, L. K.; Demerac, S.; Elmes, B. C.; Loder, J. W.; Swan, J. M.; Teitei, T. Aust. J. Chem. 1967, 20, 2715-2727.

(67) (a) Gribble, G. W. In The Alkaloids; Brossi, A., Ed.; Academic Press: New York, 1990, Vol. 39, p 239. (b) Suffness, M.; Cordell, G. A. In The Alkaloids; Brossi, A., Ed.; Academic Press: New York, 1985; Vol. 25, pp 89, 304. (c) Kansal, V. K.; Potier, P. Tetrahedron 1986, 42, 23892408. (d) Gribble, G. W.; Saulnier, M. G.; Obaza-Nutaitis, J. A.; Ketcha, D. M. J. Org. Chem. 1992, 57, 5891-5899. (e) Ishikura, M.; Yaginuma, T.; Agata, I.; Miwa, Y.; Yanada, R.; Taga, T. Synlett. 1997, 214-216. (f) Díaz, M. T.; Cobas, A.; Guitián, E.; Castedo, L. Synlett. 1998, 157- 
158. (g) Ergün, Y.; Patir, S.; Okay, G. J. Heterocycl. Chem. 1998, 35, 1445-1447. (h) Ishikura, M.; Hino, A.; Yaginuma, T.; Agata, I.; Katagiri, N. Tetrahedron 2000, 56, 193-207. (i)

Anderson, W. K.; Gopalsamy, A.; Reddy, P. S. J. Med. Chem. 1994, 37, 1955-1963.

(68) (a) Sharaf, M. H. M.; Schiff, P. L., Jr.; Tackie, A. N.; Phoebe, C. H., Jr.; Martin, G. E. J. Heterocycl. Chem. 1996, 33, 239-243. (b) Cimanga, K.; De Bruyne, T.; Pieters, L.; Claeys, M.; Vlietinck, A. Tetrahedron Lett. 1996, 37, 1703-1706.

(69) Cimanga, K.; De Bruyne, T.; Pieters, L.; Vlietinck, A. J.; Turger, C. A. J. Nat. Prod. 1997, $60,688-691$.

(70) Kononova, V. V.; Semenov, A. A. Khim. Geterotsikl. Soedin. 1982, 1211-1214.

(71) (a) Miyake, S.; Sasaki, A.; Ohta, T.; Shudo, K. Tetrahedron Lett. 1985, 26, 5815-5818. (b)

Ketcha, D. M.; Gribble, G. W. J. Org. Chem. 1985, 50, 5451-5457. (c) Saulnier, M. G.; Gribble, G. W. J. Org. Chem. 1983, 48, 2690-2695. (d) May, C.; Moody, C. J. J. Chem. Soc., Perkin Trans. 1 1988, 247-250. (e) Viossat, B.; Dung, N.-H.; Lancelot, J.-C.; Benazeth, S.; Rault, S.; Robba, M. Chem. Pharm. Bull. 1987, 35, 1724-1733.

(72) Eckert, H.; Forster, B. Angew. Chem., Int. Ed. Engl. 1987, 26, 894-895.

(73) Bödeker, J.; Köckritz, A.; Köckritz, P.; Radeglia, R. J. Prakt. Chem. 1985, 327, 723-730.

(74) Plieninger, H.; von Wittenau, M. S.; Kiefer, B. Chem. Ber. 1958, 91, 2095-2103.

(75) Estel, L.; Linard, F.; Marsais, F.; Godard, A.; Quéguiner, G. J. Heterocycl. Chem. 1989, 26, 105-112.

(76) Molina, A.; Vaquero, J.; Garcia-Navio, J. L.; Alvarez-Builla, J.; Pascual-Teresa, B.; Gago, F.; Roderigo, M. M.; Ballesteros, M. J. Org. Chem. 1996, 61, 5587-5599 and references cited therein. 
(77) Escudé, C.; Nguyen, C. H.; Mergny, J.-L.; Sun, J.-S.; Bisagni, E.; Garestier, T.; Hélène, C. J. Am. Chem. Soc. 1995, 117, 10210-10219 and references cited therein.

(78) (a) Crous, R.; Dwyer, C.; Holzapfel, C. W. Heterocycles, 1999, 51, 721-726. (b) Malm, J.; Rehn, B.; Hoernfeldt, A.-B.; Gronowitz, S. J. Heterocycl. Chem. 1994, 31, 11-16. (c) Estel, L.; Marsais, F.; Queguiner, G. J. Org. Chem. 1988, 53, 2740-2744. (d) Mazéas, D.; Guillaumet, G.; Viaud, M.-C. Heterocycles, 1999, 50, 1065-1080. 


\section{Appendix: Graphical Preview of Future Work}

Synthesis of 4-amino-3-iodopyridine (and 3-amino-4-iodopyridine) derivatives ${ }^{72}$

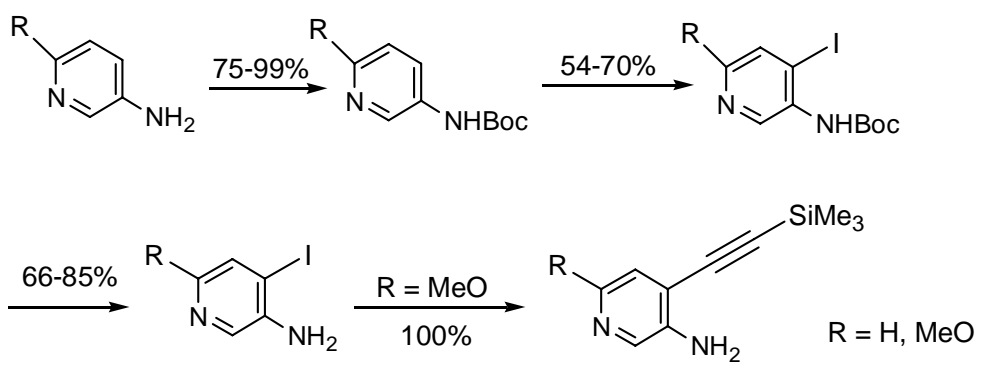

Plan
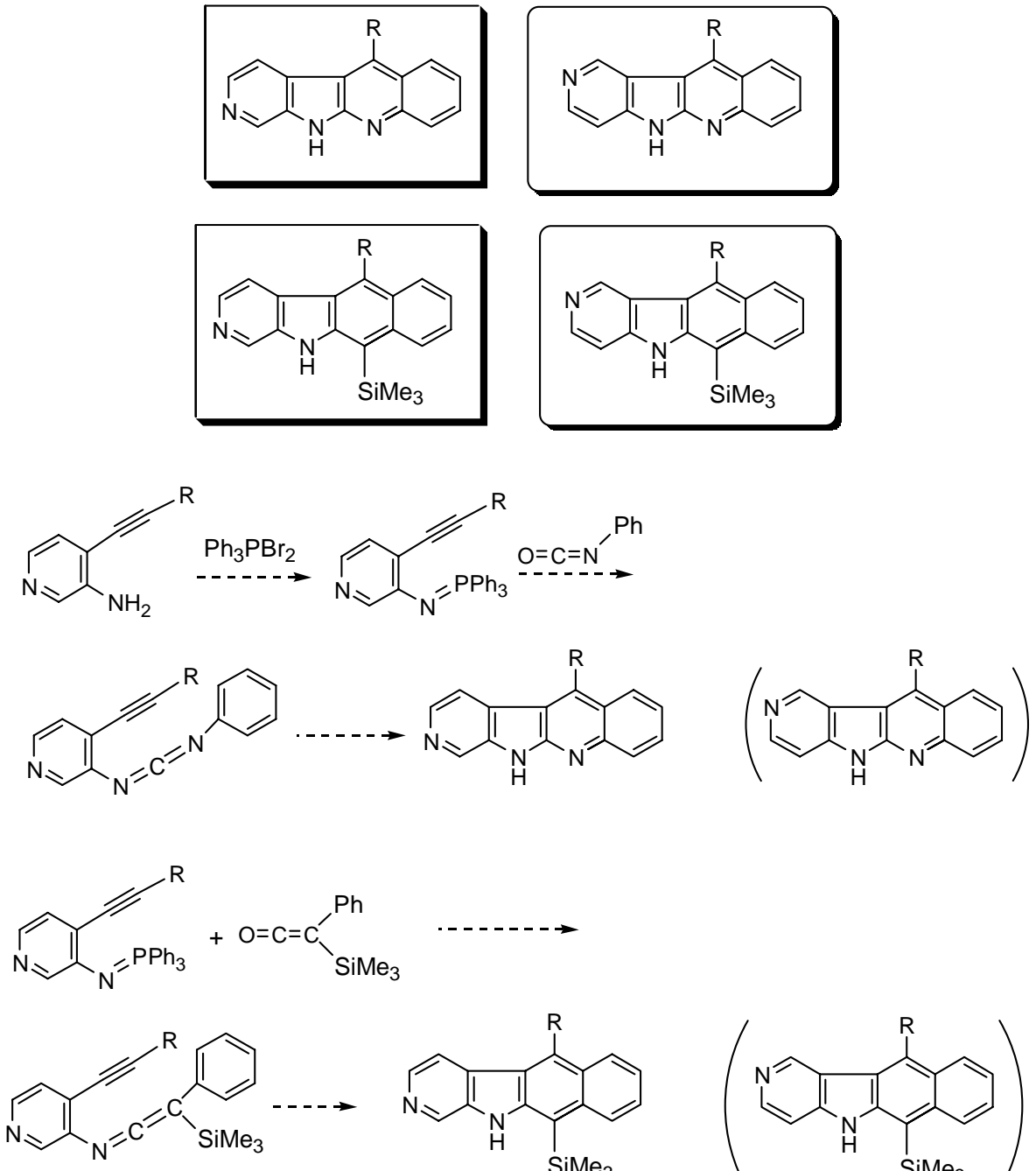<smiles>[R]c1c2ccccc2c(SC)c2[nH]c3cnccc3c12</smiles><smiles>COc1c2ccccc2c(SC)c2[nH]c3ccccc3c12</smiles> 


\section{Publications:}

1. Zhang, Q.; Shi, C.; Zhang, H.-R.; Wang, K. K., "Synthesis of 6H-Indolo[2,3-

b][1,6]naphthyridines and Related Compounds as the 5-Aza Analogues of Ellipticine

Alkaloids", J. Org. Chem. 2000, 65, 7977-7983.

2. Shi, C.; Zhang, Q.; Wang, K. K. "Biradicals from Thermolysis of N-[2-(1-Alkynyl)phenyl]-N'phenylcarbodiimides and Their Subsequent Transformations to 6H-Indolo[2,3-b]quinolines", J. Org. Chem. 1999, 64, 925-932.

3. Shi, C.; Wang, K. K. “Generation of Biradicals and Subsequent Formation of Quinolines and 5H-Benzo[b]carbazoles from N-[2-(1-Alkynyl)phenyl]ketenimines", J. Org. Chem. 1998, 63, 3517-3520.

4. Wang, K. K., Shi, C.; Petersen, J. “A facile cascade synthesis of 5,6-

diaryldibenzo[a,e]cyclooctenes from (Z,Z)-1-aryl-3,5-octadiene-1,7-diynes", J. Org. Chem.

1998, 63, 4413-4419. 